A-H[enshaw

Ornithologieat 1879 


\section{HARVARD UNIVERSITY.}

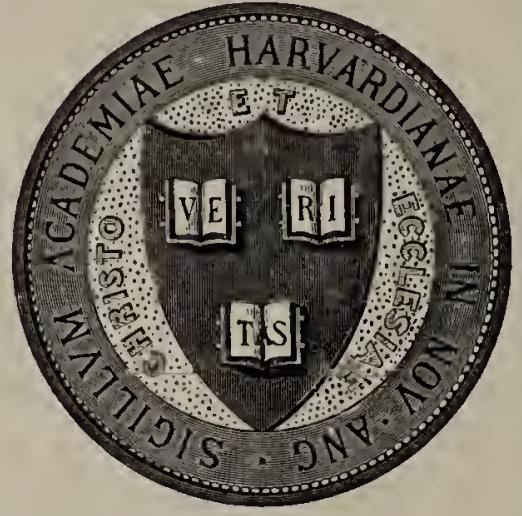

\section{LIBRARY}

OF TIIE

MUSEUM OF COMPARATIVE ZOÖLOGY $5 \underline{5,5 / 8}$

Bequest of

IVILLIAM BREWSTER

Dctober 30,1920. 
55,518

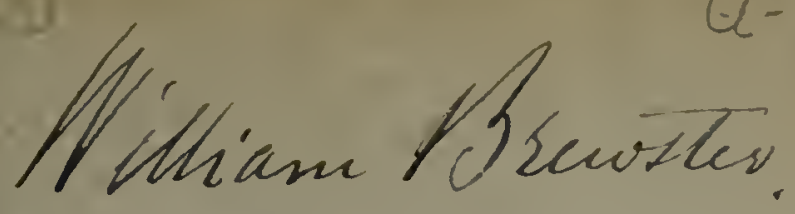

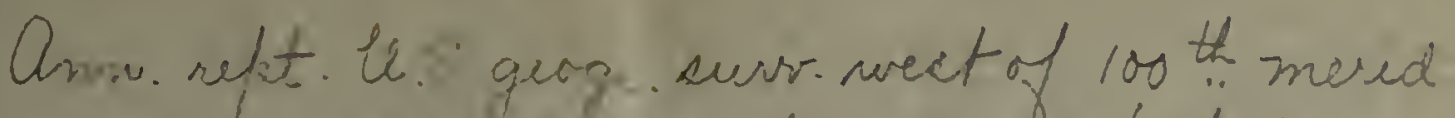
1049 . Appendix 00 of anm rept. chicf of

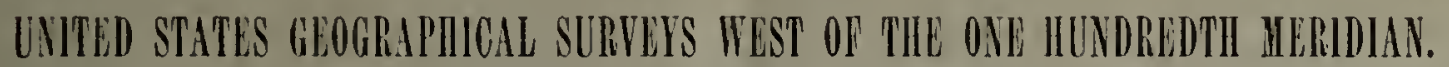

Captain GEo. M. WheEler, in charge.

\section{I lilikiliy. \\ ORNITHOLOGICAL REPORT WORE \\ UPON}

COLLECTIONS MADL IN PORTIONS OF CALIFORNIA, NEVADA, AND OREGON.

$B Y$

\section{H. W. HENSHAW.}

EXTRACTED FROM ANNUAL REPORT OF THE SURVEY FOR 1879. 


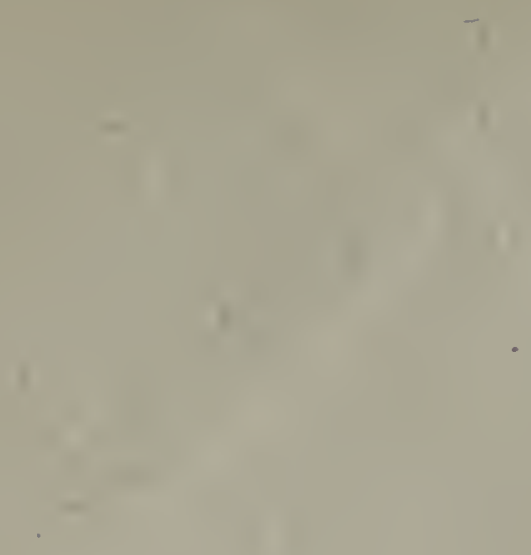

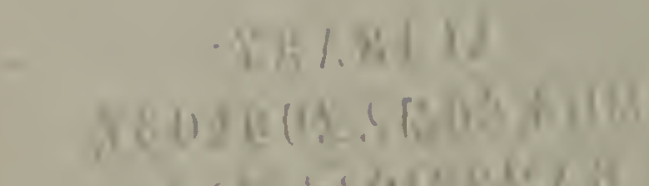

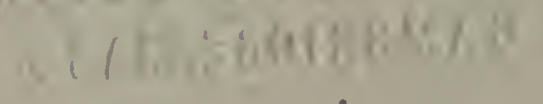

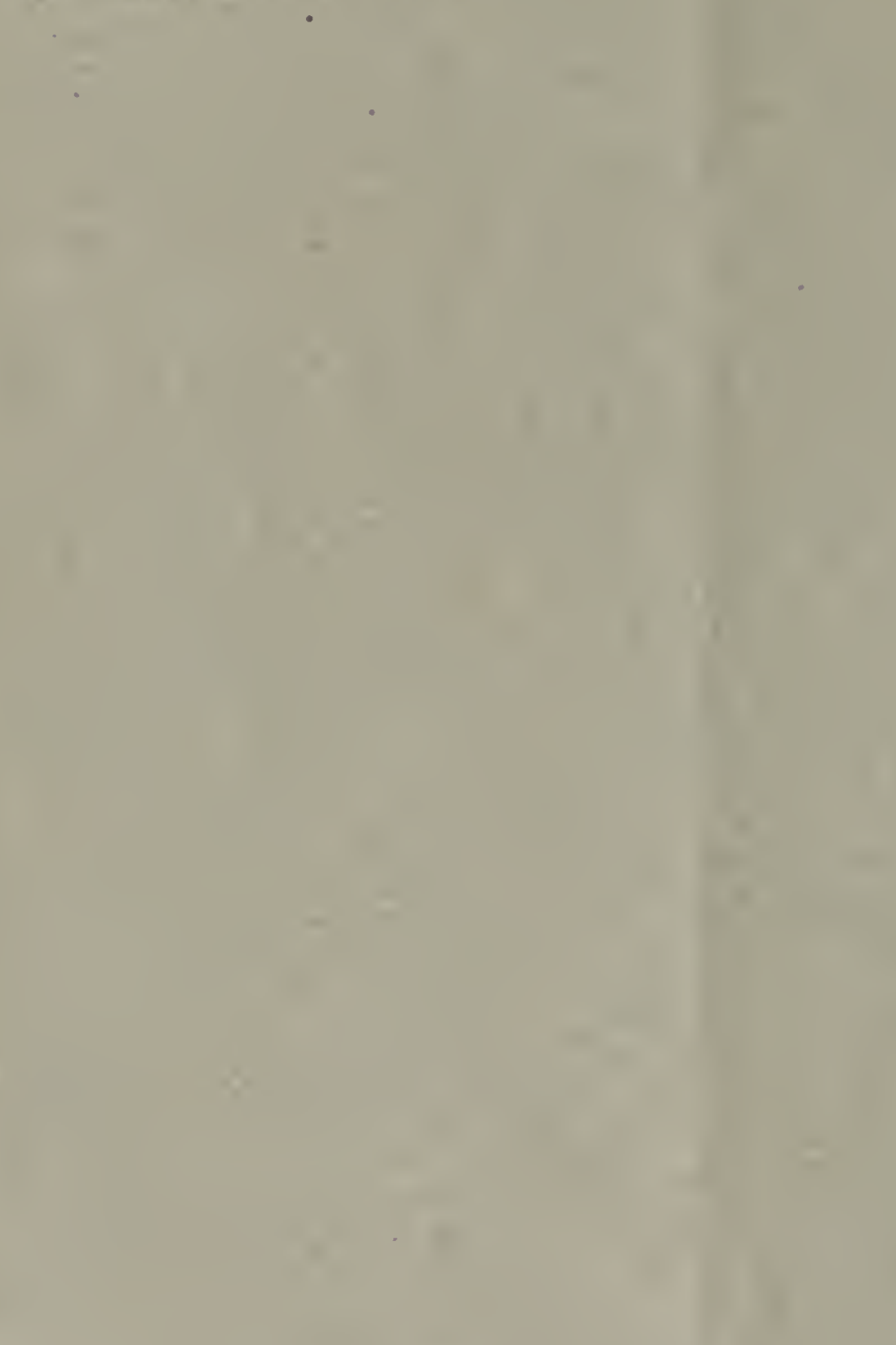




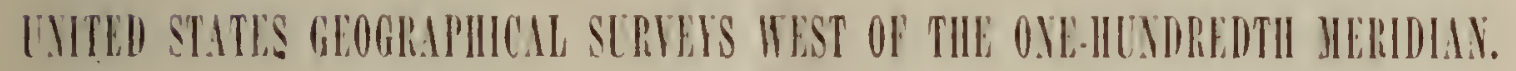
Captain Geo. M. WheELER, ix charge.

\section{ORNITHOLOGICAL REPOR'T}

THON

COLLECTIONS MADE IN PORTITONS OF CALIFORNIA, NEVADA AND OREGON.

$1: 1$

\section{H. W. HENSIIATV.}

EXTRACTED FROM ANNTAL REIORT OF THE SLRVEY FOR 18.9. 


\title{
APPEXDIX L.
}

ORNITIOLOGICAL IEIPORT FIRM OHSERVATIONS AND COLLECTIONS MADE IN IOORTIONS OF CALIFORNIA, NEYADA, AND OREGON, DY ASSISTANT II. W. IILNSIIA.

UNited States ExgINeler OFICE,

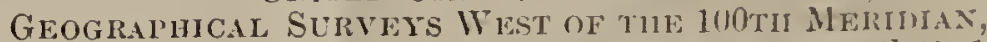

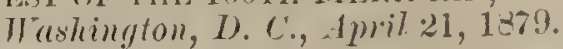

Sil: I have the lonor to transmit the following report non the ornithology of the regions visited hy me during the field seasons of $10 \% 7$ and $15 \%$.

Vers respectfulls, sour obedient servant,

\section{W. IENSIIIW.}

\author{
Capt. George M. Wheeler, U. S. A., \\ Corps of Enginecrs, in charge.
}

\begin{abstract}
The present report inclutes an enumeration of the birds nnet with during the field seasons of 1877 and 1878 by the writer, with more or less extended notices of their habits, relative abundance or scarcity, extent of habitat, \&c., \&c., from original fieldnotes and observations. To but a limiterl extent has it been thonght advisable to depart from the rule of including only results accruing rlirectly from the expedition, and to indicate hriefly general fucts respecting the distribution of spccies elserwere, as connpared with the region under consideration. In the instance of a munber of the puzzaling forms met with, a careful sturly bas been made of their relations mitl allied species and the results included in the present connection; but in the main the notes bear directly upon the area included in the examinations of the survey for the time sprecified.
\end{abstract}

In 187\%, field-work in connection with P.1ts No. 1, California Section, extended from the 12th of Mas to the 1st of October. 'lhe following Jear and with the same parts, the interval between July 18 and October 1 constituted the field season. Unfortnnatel $\Gamma$ in the latter sear work began at so late date that the much desired opportunits was lost of presenting in the present report a full acconnt of the very considerable number of species inhabiting this region, of whose nesting habits little or nothing is known. The notes therefore that bear upon this part of the birds' historics were obtained during the early portion of but a single seasoll.

The routes followed during the two years amounted practically to a continuons line from Carson, near the western borler of Nevada and a little south of the Central Pacific Railroad, to The Dalles, on the Columbia River. A considerable portion of the time was spent in the mountains, but more in the valleys and on the plains that lie at their eastern bases. Thns opportmnity was liad, so far as the necessities of the topographical parties to which the writer has usually been attiched would perwit, to malie a comparative studs of the hirds of the scveral soctions entered. Tabon in connection with what has hitherto been accomplished in thc sane region, and especially with the very valuable report of Dr.J.C. Newberrs, made in 1855, it is thought that the avifanna of the eastern slope, in its general features, may be considered as pretty well marle out. Perhaps a brief glance at the area covered in the present report, in its relations to contiguous regions, may be of intercst.

The Sierra Nerada of California, in its entire longth, and the Cascade Mountains of Oregon form essentially a continuous chain of poalis, which constitutes the first real obstacle to the extension of auimals and plants to tho restwarl that is enconntered after the main chain of the Rocky Momtains, the "backbone" of the continent, has been passed. So far, at least, as the extension of hinds is concerned, it appears to be an extremely effectual one, and the rocky barricr thus constituted may be taken as limiting with precision the Middle lamal Province.

Attention bas clsewhere* becn called to the fact that the influence of the Pacific province is risible in the birds of the eastern slope, and the conclusion drawn from a study of its avian life, that, while by no means a tspical portion of that province, it is set sufficiently dashed by Pacific province forms as to more properly be included in that zoological division rither than with the middle region. The number of species and varicties of birds typically representing the Pacific province that are found along the easteru slope is not very great, since, of course, thes are limited to momtain-inbabiting forms that constitute but a small proportion of the argregate nnmber belonging thereto. On the ofluer hand I know of bnt four species strictly attribntable to the middle region that reacl into the monntains of the eastern slope, viz, Turdus pallasi auduboni, Capodacus cassini, P'ica melanolenca hudsonica, and Tetrao obscurus. 'That the

* Annual Report of Geographical Survess West of the One Hundredth Meridian, 1877, p. 1301 et seq. 
number sliould be so small secms at first thought strange, when it is remembered that the low elcrations jnst east of the monntains are unmistakably middle province in the cliaracter of their avifauna.

With reference to the geological strncture of the Deschutes Basin and other areas just east of the Sierra and Cascade Ranges, Dr. Newberry affirms their intimate connection with the Rocky Mountain Desert; nor in considering the flora and fanna of these areas does he fail to note many examples that serve to indicate their closer affinity to the Rocky Mountain region than to the Pacific.

In the case of birds the physical obstacles to be surnounted, formed by the high monntain crests, although donbtless not without effect, have probabls far less to do with the absolute linitation of species than has the check offered by the conditions of a diflierent climate, with the consernent change in plant and insect life which this implics. The region west of the mountains has a large mean anznal rainfall, the effect of which upon plant and animal life is fnrther maiutained during the dry season by the accession of moisture from the ocean; but the moisture-laden winds are finally robbed as they pass eastward over the summits of the mountains, and ther reach the distant interior dry and without lifc-giving power. As a consequence, and in connection with its volcanic character, the interior plateau country, almost rainless during the sinmer, is, for the most part, dry and barren in the cxtreme. The oases, in fact, in this general descrt are limited to the areas which, throngh geological distnrbances, have been nplifter to a sufficient height to intercept cloud moistnre; and, in addition, the banks of the streams, which afford restricted ground for the grow th of vegetation, and through it a home for animal life. With the above well-defined differences of climate, it is not surprising that a corresponding change in the flora and fauna of the two regions is observable.

Although, as stated, the Sierra aud Cascade Ranges present in the main a continuons chain, its continnity is intermpted in several places, the Colnmbia, the Klamath, and the Pitt Rivers breaking through its wall in their progress to the Pacific. Nevertheless, the presence of the natnral passes thus afforded does not appear to have a marked effect npon the distribntion of birds and mammals, if, indeed, it is to be detected at all. The narrowness of their cañons, flanked as they are in the case of the Columbia by extremely dense coniferons woods, and of the others by an inhospitable descrt-like country, wonld probably have an effect in preventing the passage of species back and forth, were there no other existing cause. But, as remarked before, probably the main obstacle is to be found in the different climates of the two regions. Those species habituated to the warmer, more eqnable, and moist climate of the Pacific side, and to a country covered with profuse vegetation, would naturally be repelled by the harsher climate and dr5, desolate country to the eastward; while such as are inured to the latter conditions would find the former equally unattractive. As further evidence that it is chiefly the cli mate and the conditions resulting therefrom that limit the range of birds, and not the mere physical barriers offered by monntain chains, it may be remarked that, by no means the same amoun t of difference is to be observed between the birds of the regions that lie contiguous to the eastern and western slopes of the Rocky Monntains that is to be noted here. And we may safely infer that the very marked faunal similarity of the latter sections is largely dne to the corresponding similarity of climates, the Rocky Monntains appearing to 'have little or' no effect in limiting the range of birds and mammals.

In a region possessing the forbidding aspect of that to the east of the Sierras, it might be inferred that the sum total of bird life would be rather small. In general, this is trne; bnt along the strcams there is usually to be noticed a rather marked conccntration of species, while in some favored localities the number also of individuals is great. The mountainons districts, with their heary growth of conifers and decidnons shrubs, as well as their profusion of annual plants, which up to a certain limit accompany the increased amount of rainfall, form the home of nnmerons species not found elscwhere. In fact, the more favorable localities in the mountains form the best collecting grounds for the naturalist.

A somewhat special type of conntry was entered during the past season in the Deschutcs River region, the general watershed of which stream has elsewhere bcen termed the "Deschutes Basin." As it is peculiar in some of its aspects, this region merits brief mention. With a general ele vation of about 4,000 feet above sea-level, much of this area is corered by a nniform growth of the yellow pine (Pimus ponderosa), which appears to thrive wonderfully well in the light soil of pulverized pumice. From the fact that qhe water supply is extremely limiterl and occurs for the most part only as small springs or in water-holes, very few shrubs and plants are able to maintain existence, and a hardy kinll of grass alone covers the soil with a scinty growth. So far as birds are concerned, it wonld be difficult to realize a more complete t5pe of desert than is here presented. For days in succession, I have ridden through these forests, the mules each step sinking above the fetlock in the treacherous dnst, which, rising in clonds, marked the ronte of the party as by a colmmn of snoke, scarcely seeing or hearing a bird. The rare note of a woodpecker or nuthatch, or the chirpings of a few venturesome snow- 
birds, alone broke the silence of the woods. Even along the banks of the Deschntes there was noticeable at the time of ms visit, in September, a remarkable porerty of birds. This I attributed, in the lack of other apparent canses, to the fact that the slmbbery of its banks consisted only of willows, while a heavy glowth of coarse grass replacer the bright flowers and varied vegetation of higher allitudes.

Notable as are these forest deserts for absence of bird-life, they yet form the hom for thousands of mule-deer and antelope. 'The former, although gencrally dispersed, ccuter in gleater numbers in certain spots, which are regulated probably by their accessibility to water, and not a day passed withont many being started by onl train.

The mule-rleer, as nearly as we conld learu, reaches only into the monintains of the eastern slope, and does not pass the smmuit; a somewhat singmlar faet in regald to its ristribution, since it reaches (puite to the cuast in the region sonth of San Francisco. Tothe rest, in Northern California and Oregon, it is replaced by the Patifie black-tatiled deer ( $C$. colmeliamus). This animal, while in the main coufinerl to the region wrst of the uountains, was ascertained to cross the range at a number of points and inhabit the same sections as the $C$. macrotis. This, however, is the exceptiou rather than the rulc, the astern slope, as a rule, appearing to be free from its presence.

Along the Dechntes Rirer we net with the white-tailed deor, the so-called C. lencmrs. In comparison with the mule-deer it was not numerons, and its rauge alpeared to be confined to the river-bottom and to the forcst closely arjacent.

The antelope, typically an aninal of the open grassy plaius, concentrates more in the "dealenings," which are of ten of many hnurled acres in extent, or live in the sections where the pines dwindle away and are leplaced bo a growth of cedar. Still, they were not inflequently net with in the pine woods, their haunts here thus furnishing a stroug contrast to the usual home of the species further east.

In comnectiou with my work. my grateful thauks are due for the many courtesies and rery material assistance rendered by my friend Mr. H. G. Parker, of Carson, Nev. I am also greatly indebted to Maj. J. M. Norvall, at the time of my visit in commaud of Camp Bidwell, for the generous hospitality received at his hands. Duriug my stas with hin every possible aid to my investigations was freely extended. I would also gratefully mention the aid received from my friend Mr. Robert Ridgway, of the Smithsonian Institution, in the shape of facilities extenderl in connection with the study of specimens, as also for many valnable suggestious.

\section{TURDIDA-Thrnshes.}

\section{Turdus Limneus.}

\section{T. migratorins propinquns Ritgrw. Westorn Robin.}

This variety of the common robin is found thronghout this whole region as a summer visitant, and is more or less abundaut accorrling to special locality. In Nevada, the bulk of individnals arrive from the sonth in March, and spend the early spring in the low and sheltered vallezs. As summer advances they make their way higher and higher up on the mountain sides, where they in habit preferably the aspen groves. "The species begins to lay in the neighborbood of Carsou about the mirblle of May. A considerable number of pairs rear their first broods here and in ofler similar low ralleys. But as soon as the young are on the wing all withdraw, apparently to the mountains, and by $\mathrm{Jnly}$, when the lowlands are dry and parched, the sight of a robin is extremely unusual.

Robins were fairly nmmerous in Oregon, along the Colnnbia River, during the last of October, and a few doubtless winter cven at this high latitude.

\section{T. navius Gm. Varicả Thrush; Oregon Thrush.}

This fine thrush is chiefly known to ns as it occuls during fall and winter at points far south of its smmmer home. Apparently its breeding range is wholly confined to the regions west of the Cascade, and perliaps the northeln Sierra ranges, from a point somewhere about the Colmmbia River northward. Even in October I saw but a single individual at The Dalles, while a day's march down the Columbia toward the west slope of the Cascades loronght me to where the species was very numerons.

Flom my friend Mr. H. G. Parker I have information of the occurience of this thrusl near Reno, in Western Nevada, just at the base of the Sierras, thus confiruing its supposed presence here, as mentioncd in a previons report (1877). Verg large numbers wade their appearance in this neighborhood abont Febrnaly 1, probably from the mountains to the westward, and remaiued till into March. Doubtless this is not an unnsual event in the history of this species, and we may consider its winter habitat as includiug the main chain of the Sierras on either slope.

The four instances known of the occurrence of the varicd thrush along the eastern coast must be looked upon as wholly exceptionable, cspccially as no cases a re on record of its appearance oven in the remoter westeru States to the east of the Sierras. 
Habils.-As the result of my own observations I can add but few details respecting the habits of the varied thrush. In the fall it is not a bird of the open, but appears to pass most of the time in the dense crergreen woods, where it obtains from amongst the low shrubbery varions linds of berries, which eridently form its chiof fere at this seasolt. Under my observation it bore out its ascribed character of heing a rather shy and snspicions bird, and it was ouly upon occasions that I sncceeded in pushing my acquaintanceship to close quarters. While maling my way along the innumerable old wood-roads and tangled bridle-paths that intersect the pineries in all clirections-relics of the wookchopper and linmerman--nnsinspecterl, I frequently came mpon small tlocks of these thrushes. The alarm-note is a single lond chuck, frequently repeated, and is very similar to that of the small olive-hacked thrushes, but nuch londer. A very few moments upon such occasions sufficed to sce the hand dispersed in alarm, and each seeking a safe position towards the tops of the tall, thick firs and spruces, in which they invariably took shelter. Altogether there is much in the habits and notes of the species that is suggestive of the smaller members of the genus, and it certainly resembles them in more particulars than does the robin. Still its size, its gregarions disposition, and its partiality for berries, naturally canse it to be associated in thought with the robin.

I saw many nests in the crotches of the sulall firs and npon brusby saplings that, under casuril notice, much rescmbled the nsinal structure of the robin, but some of which were probably constructed by the varied thrush. Not recalling to mind at the time how readily identifiable the nest of this species is-constructed without mul-I neglected to examine these structures critically. That more or less remain to breed in the dense forests along the Columbia seems in the highest degree probable, and, in fact, I was informed by lnmbermen that both "robins" remained all summer.

\section{T. pallasi auduboni (Baird). Audubon's Hermit Thrush:}

During the past summer the important fact was ascertaince that this form of the hermit thrnsh, instear of being strictly limited to the Rocky Mountains, as has hitherto been assumed, crosses the basin and breeds along the eastern slope of the Sierras. During the summer of $187 \%$ I heard, in several of the subalpine valleys of Northeastern California, what were withont doubt the Andubon's thrnshes, but failed to secure specimens. Here they were evidently not very numerons; but in the mountains back of Campl Bidrell, the succeeding season, the same thrush was heard, and this time was satisfactorily identified by shooting the bird. They were here very alouudant, and at this clafe, July 19, the pine woods were filled by the sweet music of the malcs.

\section{T. pallasi guttatus Pall. Dwarf Hermit Thrnsh.}

The dwarf thrush appears to occur along the eastern slope, as it does in the Rocky Mountains, only as a migrant, and as such perhaps only in the fall. By the last of Angust it was found numerous along the foot-hills of the Cascade Range of Oregon.

I consirler it very probable that the sonthern breeding limit of this form will eventually be found to include the momutains of Oregon, upon their western slope; but we have no facts of observation to fully bear ont such a conjecture.

\section{MYIADESTINÆ-Fly-catching Thrushes.}

\section{MYiadestes Swainson.}

M. tormsendi (Aud.). Townsend's Fly-catching Thrush.

This bird was found by our party to be very abundant in the Daschntes Basin in September, where, too, it was reported by Dr. Newherry in 1860. In fact, I have never seen the bird congregated in such numbers over so wille an area as bere. In fall and winter it appears to be generally dispersed over mnch of the country arjoiniug the eastern slope, where in summer it appears to be almost entirely absent. During the summer of $18 \%$ I saw bnt a single individual in the monutains of Eastern California, althongh the condition of this individnal, a male, indicated that it was mated and breeding, so that it is to be presumed that the multitudes that throng here in fall localize themselves in some favorable section during the breeding period.

The localities affected by them in Oregon in fall are almost exactly similar to their range in New Mexico, Utah, \&c., a fact which sufficiently establishes their natural predilections. It is as desolate a type of comntry as one can well imagine, being corered everywhere with voleanic débris, which is thrown up in the shape of low hills or scattered broadcast over the general expanse as though the unsightly blocks had rained down. Ravines with their rocky ridges scar and seam the country in every direction, while an almost total absence of vegetation, except in the shape of dwarf cedars or stmuted piñms, renders such a region a desert indeed. Of such a nature is the coluntry to the sonth and west of Prineville, Oregon, and here a day's mareh along the road revoaled many hundreds of these fly-catching thrushes. 
It is a cmious fact in the history of this species that, in the fall, when the scason of love, which is supposed to directly inspire the music of birds, has long since passed, and most other songsters are either entirely silent or their songs are limited to the first rude practicinirs of the young males, the Townsend's flyeatcher should nownot at rare intervals, but as a regular habit-give ntterance to sinatehes of melody that, though but a fraction of its splendid powers, may yet challenge the ntmost efforts at emulation of most other species. And I an by no means sure that such musical rivalry as takes place at this time among the males does not owe its origin, in part at least, to the fading embers of a passion not set fully spent. At all events, I have often seen, at this scason, two males in eager pursnit of a companion-apparently some coy female - that led them an earer chase for five or ten minutes at a time, in a way that could suggest only the ardor of the mating scason. The males engaged in such a chase are always full of song, which ponrs out as brilliaut suatches and fragments of their fuller, nore perfect symphonies of spring.

\section{Oroscoptes Baird.}

\section{O. montanus (Towns.). Sage-Thrasher.}

Nowhere in the wide region inhabited by this thrush is it more abundant than on the sage-covered hills and plains of Western Nevada, just at the base of the mountains which shut off the western exteusion of the spccies.

In a climate like that of Nevada, where the transition period from spring to snmmer is never very well marked, and summer is at hand almost as soon as the snow disappears, there are always to be observed great irregularities in the time of nesting of the birds. This is as true of the smaller as of the larger species. Thus, taking the present bird as an example, the 20th of May appears to be just about the lieiglit of its brceding season. Although at this time not a few pairs were feeding full broods, yet the majority of the nests contained fresh eggs, while some dilatory conples had but just bronght their homes to completion. There was thus to be noted a difference of fully six weeks between the earliest aud latest periods of deposition of the first clntches of egrs.

As the eje passes over the sage plains of the far West it finds a loroad, slightly undulatory expanse, covered everywliere with the characteristic sage-brush and presenting to the sight no breals in its apparently smooth surface. In reality, hotever, the plains are very far from being level, and it needs but a short walk in any direction to reveal the presence of nususpected little valless and ravines, their bonndaries traced on either side by nore or less abrupt rockp ridges. It is along the crests and sides of just such ridges that the sage-thrasher is most at home, and in the vernal season, at intervals of every few hundred yards, the males may be heard pouring out at all times of day their delightfully melodious strains. In the presence of its humble associates, the Bell's finch and Brewer's sparrow, which alone share its desolate surroundings, onr thrush finds no rivalry to stimmlate its efforts; bnt, ummindful of this, it sings on, finding, perhaps, its reward in the satisfaction born of its own powers or the delight its strains carry to the heart of its silent brooding mate. Its song, though not possessed of great variety, is noteworthy for its sweetness and expression.

The nests, of which I have examined very many, vary but little either in composition or sitnation. Solidity and bulkiness sum up their clief characteristics. The foundation is of sticks and twigs, the thorny character of which enables them to be firmly interlocked, so as to form a strong support capable of resisting all ordinary accidents, and even to defy wind and weather for uans successiveseasons. I do not think, lowever, they aro ever utilized a second time. The inner or nest proper is made of rootlets, with perhaps a fow horse-hairs, which are woven into a circulardepressed cup.

Numerous sets of egas compared together show but little variation, and this cliefly in the amount and methed of distribution of the spotting rather than in the colors themselves.

\section{SAXICOLID E-Stone Chats.}

\section{SIAlia Swainson.}

\section{S. mexicana Sw. Mexican Bluebird; Chestnut-back Blnebird.}

This is the common bluebird of the region. During the smmuer it inbabits not only the low valleys, but, to even a greater cxtent, the monntains, being there found in the deuse pine timber up to abont 6,000 feet. As is the usual custom of the Eastern species, the present bird, as indeed also the Arctic, raises two broods during the stummer, and the season is far advanced ere family dnties cease.

\section{S. arctica Sw. Arctic Bluebird.}

The habitat of the present bird is, in general, more northern than that of the precerling. Nevertheless, the two species are not infrequently unarked in local lists as inhabiting 
the same distriets at the same season. When sneh is the case, the present species is usually fonnd at ligher altitudes in the monntains, whenee it descends in fall and winter to the same neighborhood where the ehestnut-back blnebird makes its summer home. Their eonnection is henee not so intimate as might natnrally be inferrer.

The statament of a more northerly babitat for the Aretie bluebird is true only in part; sinee, while it attains bigher latitudes and, eoincident with this, seeks out higher elevations in the mountains, it jet was found breeding by our parties as far south as Santa F6, and here, too, entirely ontside of the mountains. This probably represents abont its sontlern breeding limit, while, on the other band, mexicana does not reael innel farther sonth.

A nest of arclica, probably the seeond of the season, was found July 31 in a dead pine stub. It eontained five eggs, far advaneed.

\section{CINCLID A-Water Onzels.}

$-$

\section{Cinclus Srainson.}

C. mexicanus Sw. American Dipper.

Common upon many of the streams of the eastern slope, where noted as high up as the Columbia River.

Concerning the habits of this interesting speeies, I have no new faets to add to the extended notices which have appeared elsewhere, nore partieularly as they seem to he everywhere about the same. In reading Maegillivray's excellent account of the. European dipper and its mode of life, I notice a statement to the effeet that the dipper is by no means an adept at walking on land; he says, after denying its alleged absurd habit of watking in the water on the bottom : "Even on land I have never seen it move more than a few steps, which it aecomplished by a kiud of leaping motion. Its short legs and eurved elaws are very ill-adapted for running." * * * Sueh being the case, it wonld appear as thongh there is, in this particular, a very marked differenee between the European bird and onr own; for no one who has made the acquaintanee of onr dipper in its native hannts would hesitate for a moment to affirm that it is both agile and graeeful in its movements on land, if graee be understood to mean an easy and assured manner. Possessed apparently of equal powers for progression under water with its European ally, our speeies by no neans depends wholly, or at times even in great part, upon these for its subsistenee; bnt, on the contrary, may often be seen for an hour at a time waling in the shallows, or runniug quiekly over the wet roeks or along the pebbly shores in search of food, when its aetivity and nimbleness of movement are very apparent. In fact, its amphibions nature would appear at times to be almost forgotten, or to be ealled to its aid only for very brief intervals; while, again, it appears on land, only to disappear a moment later in the swiftly moving current.

\section{SYLVIIDA-True Warblers.}

Regulus Cuvier.

R. caleudula L. Ruby-3rowned Kinglet.

A common summer inhabitant of the pineries. Its songs, Joud, elear, and harmonions, were heard all dhy long issuing from the tall, thiekly-foliaged firs and sprnees, in which, without doubt, the nests were seereted.

\section{CERTHID Æ-Creepers.}

Certhia Linnelus.

C. familiaris L. Brown Creeper.

A enmmon summer inhabitant of the eoniferous belt all along the eastern slope.

$$
\text { TROGLODYTID E-Wrens. }
$$

SALpinctes Cabanis.

S. obsoletus Say. Roek Wren.

A common summer visitant throughout this whole region. Its love for roeky fastnesses is well typilied in its name. Its nest is often plaeed beneath the shelter of a rock, or, as I have on several oceasions seen it, in some slight reeess or natural eavity in a sand-bank; in faet, any hidden nook or natnral reeess that promises eoneealment is available for its purpose. A nest found on the 15th of May eontained eight eggs, 
the soung in. which were just ready to chip the shell. The rock wren is thus among the very first of the small birds to lay. The eggs vary so little as to be easils eharacteristie of the speeies; ground-eolor pure white, with a ratler eren distribution over the entire surface of minute, roundish, reddish-browu spots.

\section{Trogloditrs Yicillot.}

\section{T. celon yarkmami And. Western Honse II ren.}

Numerous as a summer resident all along the eastern slope. As a rule, kecps in the timber of the uncivilized districts, and seems rather loth to aceept the accommodatious offered in the towns, where, howerer, it is oceasionally seen.

\section{T. hyematis pacificus Bd. Western Winter Wren.}

This bird was not net with until the Colmubia River was reached; here in Oetolser it was found to be very abundant, wore so, in fact, than I lave ever known the winter wren to be elsewhere. Nearly every brush-heap eontained at least one. of these sputtering, scolding mites, while not rarcly scveral were heard or seon in the space of a few yards. It was found on both slopes of the Caseades, althongh it was not nearly so unmerous upon the east side of the mountains as upon the west. As fall adramees, it finds its way farther south, and reaches on botl slopes as low as the latitude of San Franeiseo. I am inclined to believe that it brecds all through the pine woods of the momtains near the Columbia. It winters here, as also, according to Cooper, in IVashington "Territors.

\section{Cistotholius Baird.}

C. palustris Wils. Long-billed Marsh Wre

Extremels alnudant in all the tule marshes.

PARID E-Titmice.

Loprophanes Kaup.

\section{L. inornatus (Gamb.). Plain Titmouse.}

This species is present in Nevada in the foot-lills of the monntains and on the low ranges to the east of the main ehain. It was not met with in the Columbia Rirer region, nor even in Northern California.

\section{PARUS Linnaus.}

\section{P. mfescens Towns, Chestuut-baek Chickadee.}

Aecording to Dr. Cooper, this specics is the most abundant of the family in Washington Territory, where, however, it is probably limited for the most part or entirely to the districts west of the monntains. Sueh, at least, appears to be the ease in Oregon, where the speeies did not fall under my observation until at the Cascades on the western slope, where I saw a single small flock in October. It is probably a snmmer resident here, and perhaps even farther sonth in Northern California. In fall it migrates to below San Franeiseo, but does not appear npon the eastern sicle of the ehain.

\section{P. montanus Gamb. Monntain Chiekadee.}

Breeds nnmeronsly among the pincs. Extremely abnudant among the oaks of the eastern slope, near the Colnmbia River.

\section{Psaltpiparus Bonaparte.}

\section{P. plumbcus Bal. Plumbeous Titmouse.}

This chickadee, which is peeuliar to the middle province, extends its range elear to the foot-hills of the Sierras, but does not enter the nom tains. 'Thus, among the barren piñon hills near Carson City, I saw, in Juls, a flock of twenty or tuirty indiriduals.

\section{SITTIDE-Nuthatehes.}

\section{SitTA Linnaus.}

\section{S. canadensis L. Red-bellied Ninthateh.}

This species appears so mneh oftener in the local lists of the Eastern States thau of the Western that many oruithologists have come to regard it as a quite typically east 
ern species. Nevertheless, in the extreme parts of the Vest, as upon both sides of the Sierras, from the line of the raiload to the Colnubia River, and so on to the north, the red-helliod nuthatch is really a common bird, and in much of this area it donbtless brcels. It appears to be the presence of a conntry suitably timbered to meet its wantspine-lorer as this spccies pre-emincutly is-more than anglit else that determines its presence or absence. In arlition, its distribution is clearly gorerned by its preference for a cool climate, such as it finds in the north or in the high Sierra Nerada.

Towards the Columbia Rivel it was observed to become more numerons, and npon the upper Desclntes its numbers, in certain localities, were comparable with those of the piging nuthatch.

S. corotinensis aculentu (Cass). Slender-billed Ninthatch.

A numerons and constant resiclent among the conifers; not so common toralds the Columbia River as either of the other species.

S. mymare Vig. Pigny Ninthatch.

The most numerous of the family in the Sierra Nevada and Cascade Monntains, as almost evergwliele through the West.

\section{SYLVICOLID A:-American Warblers.}

Hrimthomaga Cabanis.

H. celruta lutcscens Ridgr. Western Orange-crowned WVarbler.

Moderately common in summer when inhabiting the monntain slopes, bnt most numerous during the fall migration.

\section{Dexingerca Gray.}

D. astiva (Gm.). Tellow Warbler.

Numerons as a summer resilent in the shrubbery of the streams, which the specics follows up to an elevation among the mountains of at least $\delta, 000$ feet. It penetrates beyoud the Colnmbia and into IV ishington Territory.

D. towusendi Nutt. Townsend's Wrarbler.

This bird, which I had hoped, though scarcely expected, to find a common resident of the coniferous belt of the Cascarles in Oregon, was met with but twice. in September. In each instance the individual was migrating in compans with flocks of Audubon's warblers and other birds.

In full plumage the Townsend's warbler is one of the nost beautiful of the family, as it has been nntil a contparative recent period one of the rarest. Since it was fould by the expedition of 1874 to be a common migrant in the mountains of Southeastern Arizona, numerons specimens have been received by the Smithsonian Institution from California, notably from near Sacramento, where obtained by Mr. L. Belding. This warbler appears to be only a casnal nigrant along the line of the eastern slope, and, in three seasons' collecting, the two mentioned abore represent all I have seen. On the Pacific side, however, it is comparatively numerous, both in spring and fall. As to its breeding range, I can find no evidence on record that warrants the statement that the species finds a summer home within our territory. Still it would not be surprising were it eventually found to summer in Oregon, in the dense pine-belt to the west of the Cascade Monntains. If such is ascertained to be the case, this, at least, is likely to prove its extreme sonthern limit. The fact that the statements of its occurrence in tho United States have always been accompanied by the term "migrant," affords pretty conclusive proof that as a species it summers in the far north.

Such migrants as are found in the Rocky Mountains in fall, at which season they alone, have been noted, are to be reasonably aceonnted for as having followed this path from the extreme northern points of that raige, where it approaches the Pacific.

D. auduboni (Towns.). Audnbon's Warbler.

Conmon as a summer resident anong the conifers at high elevations; most numerons during the migrations, being, in faet, the chief representative numerically of the Sylvicolicle along the eastern slope.

\section{Geothlyrs Cabanis.}

G. trichas L. Maryland Yellóm-throat.

By no means uncommon in Western Nevada. in situations similar to those frequented by the spccies in the East. A nest found at Washoe Lake, Yevada, May 23, contained four eggs far adranced toward hatching. 


\section{G. macgillirrayi Bd. Maegillivraj's Warbler.}

Fairly numerous in snmmer along the eastern slope. I find no referenee to the speeies in my note-book as oeeurring farther north than Northern California. As, however, aecording to Cooper and Suekley, it reaehes to Puget Sound along the eoast, it is safe to infer that on the eastern slope it passes the Colnmbia River into Washington Territory.

A nest found July 24 eontained four joung a few days old.

\section{ICTERIA Vieillot.}

I. virens longicauda (Lawr.). Western Yellow-breasted Chat.

A rather eommon summer visitant abont Carson, Nev., but beeoming less so to the northward, until, in extreme Northern Califoruia, it is qnite rare.

\section{Myiodioctes Audnbon.}

M. pusilluis (Wils.). Wilson's Blaek Cap.

As a summer resident of the eastern slope the speeies appears to be rare; it inas, however, be more eommon at this season towards the Colnmbia River than farther south.

June $24 \mathrm{I}$ sar a female of this speeies in an alpine valley of Northern California, at an elevation of abont 6,000 feet. Her exeitement at $n y$ presenee eonvineed me that her nest was near by; but eireumstanees not favoring a long seareh, I failer to diseover it. In fall the speeies is eomparatively eommon.

TANAGRID E-Tanagers.

Pyraxga Vieillot.

P. Iudociciana Wils. Crimson-headed Tanager.

A eomulon summer resident of the eastern slope as far to the north at least as the Colnmbia River, and withont doubt reaching in to Washington Territory.

\section{HIRUNDINID E-Swallows.}

\section{Hiruxdo Linnæus.}

H. erythrogastra Bode. Barn Swallow.

A numerous summer resident of the lowlands.

\section{TaChYcineta Cabanis.}

\section{T. bicolor (V.). White-bellied Swallow.}

This is a more or less abundant inhabitant of the eastern slope, aecording to eirenmstanees. It was not met with farther north than Northern California. Here in the monntains near Camp Bidwell it was unnerons enongh the last of July, at whieh time the pairs all had young, as was shown by their frequent visits to woodpeekers' holes in the aspens.

\section{T. thalessina (Sw.). Violet-green Swallow.}

This is an extremely abundant snmmer visitant in eertain portions of Eastern California and Western Nevada, as, for instanee, at Psramid Lake. The pyramid-like eliffs which give name to this borly of water form the abode of thousands of these beantiful swallows, whieh resort to the niehes and holes in the faces of the roek for nesting sites.

In the monntains, where it is also abundant, it seleets for this purpose the deserted holes of woodpeekers, giving everywhere marked preferenee to those in oaks. It is almost always found in elose proximity to water.

A nest found July 1 eontained tive yoning aud tro unfertile eggs.

\section{Petrochelinox Cabanis.}

P. Iunifrons (Say). Cliff Swallow.

By far the most abnndant and generally distribnted of the family. 
C. riparia. Bank Swallow.

Cotyre Boie.

Present in Jerada and Eastern California, but apparently less numerous than the following.

STELgidopteryx Baird.

S. servipennis (Aud.). Rough-ninged Swallow.

According to Cooper and Suckler, this swallow occurs als far to the north on the coast as Puget Sound; certainly present along much of the eastern slope, and donbtless extcuding into Washington Territory along this line.

I. subis (L.). Purple Martin.

Progie, Boie.

Colonies enconntered at numerous loealities among the pine woods of the mountans, where thes are quite local.

\section{VIREONIDE-Greenlets.}

\section{VIrEO Vieillot.}

I. gilcus swainsoni Bd. Western Warbling Vireo.

This viren was found to be present along the eastern slope as far north as Southern Oregon, and, as I have never seen it more abundant than it was in Northern Callifornia, I have no doubt that it reaelies to the Columbia along this line, or even into Washington Territory, as it does, according to Cooper aud Suekles, along the Pacific side.

Verg little can be said of its babits here that would not be a repetition of published aceounts of the Eastern warbling vireo. It is merely that bird transferred from its nsual surromulings to the wild mountain districts of the west. In the mountains near Camp Bidwell, the locality alluded to above, where the species was so numerous, I found many nests, three or four being often met with during a morning's eolleeting. They were without exception built upon small aspen trees, from three to five feet above the ground. With a lining of fine grasses, they were composed mainly of long strips of white fibrous bark, festooned externally with spiders' webs, bits of eottony sulustanees from plants, \&e. At this date, July $20-30$, the exgs were so far advanced as to render their preservation very difficult.

Tireo solitarins cressini Xantus. Cassin's Vireo.

Few birds have given rise to more perplexing doubt and uncertaints respecting their relationships than the Cassin's vireo. Fonnded by Xantus, in 1859, upon a fall specimen from Fort Tejon, its subseruent written bistory has been full of vieissitndes; for while by some authors it has been aecepted as a valid species, bs others it has been affiliated with soliturius as a variety; or', again, has been rejected altogether, and thrown into the list of synonyms of the latter bird.

From the time I uade the aequaintance of this vireo in the sonthern Rocky Mountains it has had a peculiar interest for me, more especially, perhaps, from the fact that while then, and upon the many subsequent occasions I have met with it, I hare had not the slightest difficulty in properly identifying the reeently killed speeimens or even the live birds; jet, in the closet and npon comparison with other speeimens from the West marked as solitarins, I have fomnd it extremely diffieult to draw a line between the two; in faet, un til the present time I have uever been able to arrive at ang, satisfactorg conclusion respecting the true rank of ctrsini and its kinship to solitarins. I am now fully persiaded, and trust to be able to show, that cassini is at the least something more than a speeial plumage of solitarins, which was the opinion expressed by Professor Baird in his Review of North American Birds, when, it is to be remembered, the typespecimen represented all that was known of the supposed species, the absence of material for comparison doubtless having much to do in shaping this view. Since then there have aecumulated in the Smithsonian, as the result of the eolleetions of this expedition and from other sources, twelve or more specimens that are either like the original type of ctssini, or so near it that their identity with it is beyond suspicion. It is perfectly safe to saly that, whaterer it is, thes are.

With little or no difference in size from Eastern solitarins, the type-and it is to be remarked thit certain of the recently olstained specimens not only share its peculiarities but even exhibit them to a greater degree-offers only differences of coloration. These may be briefly sumbed up as follows: Typical examples of cassini are very much duller than the corresponding plnmages of solitarius. 'The head above and ou the side, instead of heing of a decided blue or bluish asl, presents little or absolutely no contrast to the olive-brown (instead of olive-green) of the dorsum. The lores and 
orbital ring, insteal of being pnre white, are of a dull white, strongls inclining to fulvous. The green of the sides is much unixed with or replaced by brown; the under parts rencrally are of an impurc white, the result of a reneral admixture of brown. In fact, extreme examples of cussini are colored so much like hultoni that upon a color basis alone it wonld be diffenlt to distiuguish thent.

Thero are a sufficient number ot specimens at hand showing the alonve characters to prove berond a doubt that cossini is entitled to rank of some kind ; in other words, that it is unt a nere accidental plumage of solitarius. For be it noted, as stated by Professor Baird of the type, that soliturius as it is colored in the East nerer approaches tho above. The color peculiarities of cassini are to be regarded thon as entirely beyond and independent of individnal variation. Bnt, to complicate mattris, nearly every authol who has hal nceasion to treat of Western birds has lloticed specinens. evidently not typical cassiui, which he has referred with more or less donbt to soliturius. Thus, specimens of so-caller soliturius are before us fiom Wishington Territory, Oregon, California, Novada, Utah, Wroming, Arizona, \&c. Some of these are certainly very close to solitarins, and I have slwars presnmell the occnrence of that species in the VTest to be a natter that almitted of no lonbt. But a recent carefnl examination of all these snecimcis shows not one that can fairly be callen tyrical of thet bird. In snch specimens tho back is of a varying shade of grcen; the liead is nore or less ashy in contrast, while the under jarts are of a purer white than is the case with trpical cassini. It is to be remarked, however, that not only is it scarcely possible to find two of these doubtfil specimens that agrce with each other. but hy ineans of them a series can be forned that appears to grade directly from the tepioal cassini towards and almost, if not quite, into solituris. The percentage of specimens of which the statenent holds rood that they are mote like solitarins than rassini is quite small. Nenrly all the internediate specimens are really identitiable with cossini; in fact, of twenty-nine specimens in the collcetion which have heen labeled indifferently cassini and soliturius, I find that twenty are reforable to cassini, and cambot by any means be identified with solitarius. Of the remaining nine, three are so nearly interinediate that they might with abont equal propriety be assigned to either, leaving six with a decided leaning toward solitarins. It necds, however, but an instant's comparison of these with the ordinary Eastern solituius to show that although closely resembling that spccies, it wonld be going too far to say that they are typically the same. In connection with the rest of the series thes are clearly intermediate, but on the solitarills side of the line.

The testimony of the series as a whole seems to show pretty conclusively that the solitary vireo proper loes not occur in the West, and that all specinens which have been so identified are either cassini or are intermediate between the two; the latter class, in fact, furnishing the evidence that the two inter-yrade, and honce that cassini is a variety of solitarins.

The only alternative wonld be to throw cassini ont entirely and refer all Western specimens to solitarius. But. in our julgrment, typical specimens of cussini a re now too numerous and show too decided and constaut ditterences to warrant such a procednre.

The habitat of Cassin's vireo may receive a moment's attention. Its summer home appears to be strictly limited to either slope of the Sierra Neradas, from IVashington Tervitory to Sonthern ('aliforuia. I can tini no specimens (including under the head of cassini all individnals hitherto supposed to be solitarius) from the Rocky Mountains in spriug or summer.

As a migrant in fall the occurrence of the Cassin's vireo in the latter range is not surprising, or no more so than that of several other Sierra Nevadan birds, as Juluco hyemalis, Turdus pallasi uanus, Dcudioica tourendi, and occidentalis, sc.

I have alluled in a foot-note below to a specimen, the coloration of which is intermediate between solitarius and plumbens. Snch specimens do not appear to be as common as in the instance of the Cassin's vireo, but I have seen too many such to render the relationship of the two former birds at all donbtful in mrown mind. With its notable increase of statnre, and the laying off of nearly all the bright tints that distingnish soliturius, plumbeus might well pass for a dittevent species, but for the fact that specimens of unquestionable intermediate character have heen ropeatedly taken; so that consistency wonld seem to demand that its near relationship to soliturus should bo formally as well as tacitly admitter. Althongh this race possesses an averare size considerably in oxcess of solilarin, the latter occasionally learls well up to its sulaller individnals. Turdus pallasi, with its race auduboni, furnishes precisely the same phenomonon of increase of size coincident with a nomntain habitat.

Of the two Western varieties of the solitary vireo, plumbeus appears to be the best marlied. This is not because typical examples of it are any uore readily recomuizable than of cassini, but becanse intermediate specimens of the former appear to be less com-

* A specimen, No. 11,06t of Nat. Mus. Pes., takon at Fort Bridger iu May by Drexler, was labeled solitarius and so referred to by anthors. This I ascertain mpon examination to bo the plumbeous rireo ( $V$. rolitarius plumbeus). Its colors are those of plumbeus, with the addition of a slight almixture of green, it beiug in fact intermediato between that form and solitarius. 
mon; in other words, plumbens appears to be further advanced in the process of differentiation, and hence to be more eonstant to its trpe. Too much stress shonld not, however, be laid npon this apparent fact, since the locality of specimens of this race appears to be an important factor. 'Thus, all specimens of the plumbeus vireo that We liave seen from the neighborhood of Fort Whipple, Arizona, the region whenco deseribed by Dr. Cones, are extremelv trppical; but from points farther north, as Forts Laramic, Bridger, and thereabouts, vearly all-perlutus all-are to a varying extent internediate.

Similarly, the eastern slopes of the Sierras and Cascales appear to furnish, in summer at least, nothiner but typical cassini, while from the Calaveras Grove California, and other localities on the western side of the monntains, we liave both typical and intermediato specinens, both strles breeding. As bearing m the subject, I nary recall the fact that manj of the shrikes from the samc localitics are scarcels distinguishable from speciuens from Florila (ludocicianus).

'I' sum 11 , the solitary vireo, like many other birds, appears to be divisible in three distinct races, according as it inhabits the eastern, the niddle, or the Pacific provinces. Facli has its own restricted snmmer babitat, where it alone is found. In fall the two Western mingle, to some extent, doring the general dispersion attendaut upon the fall migration.

'The following fignres indicate the size of each of the three forms:

Solitarius.-Average of 11 specimens : Wing, 2.92 ; tail, 2.23 ; bill, .40; tarsus, .71: laigest individual, $3.06,2.35, .32, .72$; smallest individual, $2.80,2.15, .40, .73$.

var. plumbeus.-Average of $1 \%$ specimens: Wing, 3.14 ; tail, 2.40 ; bill, .43; tarsus, .74 : largest individual, $3.22,2.45, .43, .77$; smallest indivichnal, $3.03,2.25, .43, .74$.

var. Cassini.-Arerage of 28 specimens: Wing, 2.82; tail, 2.2:3 bill, :41; tarsus, .73 : largest individual, $2.93,2.2 \%, .4 \%, .67$; suallest individual, $2.70,2.01, .43, .73$.

\section{LANIID E-Shrikes.}

\section{LANiUs Linnieus.}

L. ludoricianus excubitorides (Sw.). White-rump Shrike.

Most numerons in summer, when it lives chiefl 5 in the lower foot-hills among the sare-brush. Some appear to remain all winter in the latitule of Carson.

The northern shrike ( $C$. borealis)also appears here in fall.

\section{TANAGRIDE-Tanagers.}

\section{Prraxga Vieillot.}

\section{P. ludoviciana (Wils.). Louisiana Tanager.}

A summer visitor of the monntains, as high np at least as the Columbia River.

A nest found June 26 , near Susanville, Cal., contai ed three young and two eggs, the latter jnst on the verge of hatching. The nest was a loose structure of rootlets, similar to the usual style of the P. rubra, and was placed on the extremity of a limb of a cottonwood, abont fifteen feet from the ground.

As a rule, our tanagers lay but three eggs, and tive must, I think, be a rather unusual complement.

\section{FRINGILLIDÆ-Sparrows, Finches.}

L. curvirostra americana, Wils.

\section{Loxid Brisson.}

This crossbill becomes numerous in the mountains and ou the foot-bills in fall. It is presumably a resident in Oregon, although I cannot find an $J$ direct evidence to this effect.

\section{Carpodaces Kanp.}

C. purpureus californicus (Bd.) Californian Purple Finch.

A single individual of this species was taken at The Dalles on the Columbia in October from a flock of pine finches. This is the first record of its occurrence at any point along the eastern slope, its distribution being to the west of the mountains from as far north as the Straits of De Fuca (Cooper) to below San Francisco.

C. cassini Bd. Cassin's Purple Finch.

An abmndant summer inhabitant in the neighborhood of Carson, and, although, perhaps becoming rather less numerous as northern California is reached, the species 
persists to the Colmmbia River. This, I believe, gives it a more uorthern extension than has hitherto been supposed. In summer they are quite loeal, and erowd into a eertain neighborhood of a seetion to the total disregard of others whieh, perhaps, appear no less suited to their ceonomy. I found communities of eonsiderable size thus colonized in eertain parts of the pine Woods abont Eagle Lake, California, and elsewhere. In eommon with others of their kin they are delightful siugers, and the burst of melody whieh greets the ear of the ehanee passer by as he happens upon one of these musieal oases in the gemerally silent forests is no less pleasing than it is nnexpeeted. Like the common goldfineh (C. tristis) the males have the halit of singing in chorus, and it takes verr little imagination to eonstrue their efforts into rival eoutests. Whether they possess suel significanee to the birls themselves or not, it is certain tliat eaeh individual appears to sing his londest and best, as though trying to drown the motes of lis neighbor, or, perhaps, too well pleased with his own eifurts to eare for aught else. The effeet, as the medley of delightful strains gocs ringing throngh the leafy arches of the pimeries, is pleasing in the extreme.

'The nests, of wlich I have seen many, were all plaeed on large pines and well out toward the ends of the lower limbs.

By the latter part of June neally all the pairs were feeding young, and none of the nests that were aecessible containerl eggs.

\section{C. frontalis (Say). House Finel.}

An ahundant speeies wherever fonnd. It was not observed mueh farther north than Honey Like, Northern California.

\section{CHilsomthis Boie.}

C. tristis (L.). Common Goldfineh.

A eommon summer resident at mans points. Found on the Columbia River in Oetober.

\section{C. pinns (Wils.). Pine Fineh.}

This speeies oeeurs along the whole eastern slope in fall and winter, and passes the summer in the coniferous belt in wuch of its extent. In Oregon, from August ou, wherever I penetrated the momntains, I was almost sure to rum aeross floeks of these finehes, whose twittering notes often betrayed their presenee in the tops of the tall pines and sprnees when the birds themselves were only visible npou patient serutiug.

\section{Passerculus Bonaparte.}

\section{P. sacama alaudimus Bp. Western Savanua Sparrow.}

Nunerous in all wet meadowy lands, and as mueh so in Oregou as farther south.

A nest taken near Washoe Lake, Ner., May 22, eontained four fresh eggrs. These are rather peeuliar both in shape and in markings, although the differenees probably represent nothing but individual variation and are not distinetive of this western raee. They are of a greenish. white gronnd color, hearily blotehed in a more or less conflnent ring at the larger ends with burnt sienna and varions sbales of lavender. They are short and rounded in shape, measmring $(65 \times 55)^{2}, 66 \times 54,65 \times 53$.

\section{P. sarunna sandvicensis (Gm.). Sandvieh Sparrow.}

The preeding form is the type that prevails in summer all aloug the eastern slope. In fact at only one loeality did I deteet the presence of the present bird, viz, on Crooked River, Oregon, in September.

A sandy pasture at this point proved favorite ground for the savamna sparrows, and a walk through the weed patebes nsually resulted in starting up scores. Among the rabble I noticed one day an individual of-apparently larger size than the rest, and upon shooting diseovered it to be of the present race. Fnrtber seareh resulted in the aequisition of one additional specimen. So far as known sandricensis is a strietly eoast form; but its presenee here is, after all, by 110 means remarkable, since in the fall migration a few inight readily find their way mp the Colnubia River and so move south along the eastern slope. As I did not find it elsewhere, I judge it to be rare.

\section{Pooecetes Baird.}

\section{I. gramineus confinis Bu. Western Grass Fineh.}

Numerous in the valless. Noted no farther north than Southerm Oregon, but, without doubt, extending into Washington Territors. 
Ciroxdestes Swainson.

\section{C. grammaca (Say). Lark Sparrow.}

'This species wis lost sight of about onc liundred miles north of Carson. It donbtless occurs in the low valless, quite up into Orcgon; in fact, Suckley recorls a single specimen from The Dalles, on the Columbia.

\section{ZоготвісHA Swainson.}

\section{7. albicollis (Gm.). White-throated Sparrow.}

Dakota has hitherto heen given as formingr the westeru linit of this sparrow. Nevptheless, it scems probable that it is to be added to the list of eastcrn species that reacl the Pacitic on the northwest coast and summer at the point where the Rocky Mommtains dwindle away and admit of free passage. At all events, the presence of the white-throateci sparrow was detected on the Columbia River, abont forty miles from The Dalles, and thus beyour the eastern slope, and one of the two individnals seen was capturcd. I presmme that it is ly no means scarce here, althongh as the individwals noticed were scen only an hnur or so before camp was broken for the retum up the river, no opportnuity was had for a satisfactory investigation of the matter.

\section{7. leucophrys (Forst.). White-crowned Sparrow.}

As ahmost cverywhere thronghout the West, this sparrow occurs along the eastern slope in great mmbcrs during the migrations. It is also numerous in these nountaius in smumcr, resorting to breed to the willow thickets and aspen groves along the streans.

A nest fonnd in Eastern California, Jnne 20, contained fonr eggs bnt slightly advanced. Soveral fomd on the 24 th hell young. 'The nests were quite typical of the groundbuilding sparrows, being ontwaidly composed of weed-stalks with an interior lining of tino grasses and horse hairs, the whole snugly hidden away with a sparrow's cunning beneath a smal] linsh.

'The eggs are of a faint blnish green, irregnlarly and profusely spotted with reddish brown, which is most conspicuous at the larger ends.

\section{Z. grambeli intermedia Ridgw. Rilgway's Sparrow.}

Flocks composed of this and the previous bird frequently fall into the path of the collector in this region during spring and fall. The present bird was not found in the monntains as a snmmer resident, and I beliere it goes farther north to breed. Mr. Rirlgway, indecd, in his recent report to Kiug, ${ }^{*}$ mentions this bird as nesting in numbers at Donner Lake Pass in the Sicrras; but, as I now learn, he bolieves that his identification was incorrcet (circumstances not permittiug specimeus to be obtained), and that the species thus referred to was, bejond doubt, the $Z$. lencophrys. This agrees lully with my own experience in this region, and leares us with no record of the breoding of the var. intermedia in the Sierras.

I have elsewhere presented facts bearing upon certain differcnces in the migrations of these two Zonotriehias, and have referred to the very exteusive overlapping, eastward aud westward, of their respective habits, urging that these cousiderations, coup)ed with the coustant, albeit slight, differences in coloration between the two, were sufficient to warrant the conclusiou that inlermedia was not a race of leneophrys. I am more than ever convinced of the truth of this. The Z. leveophrys is now known to ureed on the northern frontier from the Atlantic to the Rocky mountains, aud thence to the smmmit of the Sierras, and to follow the trend of these ranges far to the southward. Over all this immense region it maintains its characters with perfoct consistency, thcre appcaring in fact to be no appreciable differences between specimens taken on the Atlautic aud others from its most remote western point. So far, then, as georraphical considerations offer any evidence, it is manifestly absurd to consicler intermedia as the "western" representative of a bird that in its typical condition is fomd in nearly every portion of the West, and that, too, breeding.

On the other hand, that the relations of gambeli and intermedia are those of species and varicty seems perfectly certain, and the two mas be so treated in perfect conformity with well ascertaiued laws of greographic variation, gambeli being the darker coast representative of the pale, more northern (?) intcrior form intermedia.

\section{$Z$. coronatu(Pall.). Golden-crowned Sparrow.}

This sparrow occurs along the eastern slope during the fall migration, but by no means in such immense numbers as distinguish its presence to the westward. On the

*Ornithology of United States Geologieal Exploration of the Fortieth Parallel, Clarence King, in charge, p. 471 . 
eontrary, its numbcrs are linited to the comparatively few that find their way into the banls of white-erowned and Ridgway's sparrows, and with then perforin tho joumey sonthward, or winter in favorable loealities. Suckles, howerer, speaks of the Golden-cromned Sparrow as an abumdant summer resident about The Dalles.

\section{Juxco Wagler.}

\section{J. oregonus ('Towns.). Oregon Snowljird.}

This snowlind appears to pass the smmmer among the mombains, from abont the latitude of Carson, Nev., northward, and is the only onc of the gentistbat inluabits the Pacifie provinee.

A nest found June 23 contained young. It was placed on a hillsille in a little pateh of an evergreen shrub that raised above the earth snftieiently to sereen the west, the top of which was sunk on a level with the gronnd. This mas have been an musnally late brood, for I had talien fully fledged joung some few lays earlier.

A second nest, fonnd Angust 2, held thee jonog, several days old.

I subjoin a deseription of the jonng in the tirst or nest plumage, renarking that in this eontition the young of all onr snowbirds resemble eaeb other very elosely, those of several of the forms, in faet, being distinguishable only witl great diffienlty.

First plumage: Prevailing tint above rufous, tho feathers streaked medially with blaek; wings and tail blackish-brown, eaeh feather edged with rufous. Throat, breast, and sides profusely spotted with black; belly of a fulrous white; sides washed with rufous; first onter tail-fenther always, usually the second, sometimes the third, white.

\section{Amphispiza Cones.}

\section{A. belli nevadensis (Ridgw.). Artemisia Sparrow.}

This sparrow breeds abnndautly among the artemisia wherever it grows, and even follows it to a considerable altitude in the monntains, althongh the sage plains, at their lower levels, appear to be the proper home of the birl. 'The speeies occurs' less abundantly in Northern California than to the southward.

In the vieinity of Carson, where I found several nests, its eggs are laid about May 15. As nesting sites sage bushes were invariably seleeted. Dried weed-stalks make up the bulk of the strneture, with an interior of the soft, fibrons sage bark, inside which is the lining proper, of sheep's wool, which is readily obtained by the birds almost anywhere in this eountry.

The eggs vary mueh in the exaet eharacter of their markings, as also, to some extent, in size. With a faint greenish-white baekground, they are spotted, mueh less heavily at the smaller than at the larger end, where the markings are often aeeumnlated into a eirele, with varions shades of brown inelining toward sienna, with lavender, and faint purple. The sienna is often laid on in the shape of seratehes or blotehes, so densely as to appear almost blaek. Altogether the appearance of the eggs of this species is peeuliar.

Two sets measure as follows: $(79 \times 58)^{2} \$ 3 \times 5875 \times 58 ;(76 \times 58)^{2} .7 \times 5 \% 78 \times 5 \%$.

\section{Spizella Bonaparte.}

\section{S. monticola (Gm.). 'T'ree Sparrow.}

A floek of tree sparrows was seen upon the Colnmbia in Oetober, but, owing to a failure to interest ing mule in the matter, no speeimens were aetnally seenred.

Dr. Cooper leaves a note to the effeet that he saw what he took to be tree sparrows in the Sierras, and Suckley obtained a bird at The Dalles in winter which he identified, per book, as of this speeies. So the tree sparrow mas be presumed to be a fall migrant and winter resident of this region on both slopes of the Sierras; but it is probably less eommon than farther east.

\section{S. socialis arizona Cones. Western Chipping Sparrow.}

A eommon smmmer inhabitant of the eastern slope. It is found in Washington Territory, west of the mountains, and donbtless to the east, althorigh it was not met with abont the Colnmbia, perhaps owing to the lateness of the season.

\section{S. breweri, Cass. Brewer's Sparrows.}

This quaint little sparrow is almost as eharacteristic an inhabitant of the sage-brush plains as the Bell's tineh. Together with the latter bird and an oeeasional sage thrush this speeies makes up the nsual avian life of these forbidling wastes and, in nmmbers at least, the Brewer's sparrow is the most eonspicuons of the three. Living often far clistant from water, and with no hint of the nsual attractire surroundings 
that we como to consider as being necessary to the happiness if not the rery existence of bird life, onr little sparrow appears to be perfectly contented with its lot and unmistakably expresses himself so in the unobtrusive bnt pleasant little songs he sends forth at odd times during the entire day.

In what appears to be somewhat exceptional instances, this sparrow varies its habitat to a considerable extent. Thus I have occasionally found the summits of the high peaks to he occupied, together with a few other species, by the Brewer's sparrow. "The low brush or "scrub" into which the luxuriant snb-alpine vegetation dwindles, as the higher altitudes on the mountains are reached, seem to offer conditions sufficiently similar to its more usnal haunts to meet all requisites. In such spots the Brewer's sparrows were often very numerous, while the presence of young birds sufficiently attester the fact that here was their snmmer abode.

The nests of this sparrow are very much like the usual structures of the "chippy," but appear to be invariabls placed in a low bush. Nuch variation appears in the shape as well as the markings of the eggs. The latter uswally occur as blackish spots and blotches; these are generally few in number, and are mostly at the larger end, leaving the greenish-blue gronnd nnoccupied for its greater part. Some specimens show no traces of black, but the spotting assumes a reddish-brown or nentral tint, ofter confluent in a ring at the larger end: Other sets have only a faint irregular freckling of the same. The smaller eggs exhibit a more or less decided pyriform shape, while those of larger size vary in the direction of a more elongated oval. The following measurements express these variations in size : $(67 \times 48)^{2}, 68 \times 47 ;(6: 1 \times 43)^{2},(62 \times 47)^{2}$; $69 \times 50,65 \times 52,65 \times 50,69 \times 53$.

\section{Melospiza Baird.}

A study of the song sparrows of the United States and adjoining regions reveals an extraordinary amount of variation, coinciding more or less closely with definable geographical areas. Others of our species are possessed of a similar wide range, but in no other are exhibited such marked variations of color and such mutations in size as in this.

The song sparrow, althongh apparently nowhere a permanent resident, in the strict meaning of that term, that is, to the extent of the same individuals remaining in the same place thronghont the jear, is yet migratory to only a limited degree; and it is probable that the change of locality with the migrations is, in the instance of none of the forms, verr marked. It is doubtless to this localization and the resulting constantlyexerted inflnence of the same circumstances of en vironment, that we are to attribute the extraordinary tendency in this bird to develop into races and offshoots, according as its range brings it under differing conditions. As Dr. Cones happily phrases it, "Migration holds species true; localization lets them slip." And nowhere is to be found a better illustration of this aphorism than is preseuted by the song sparrow.

A recent examination of the extremely large collection of song sparrows in the Smithsonian Institntion, in connection with the extensive suite gathered by the Expedition, has developed some facts that appear to be of sufficient value and interest to warrant brief mention. Here as elsewhere the variation, through which the forms are indicated, are of two kinds, viz, a variation in size and a variation in coloration; nor is it easy to say in which direction the changes are nost pronouncerl.

The only song sparrow found in eastern United States, and which extends from the coast as far west as Nebraska and Indian Territory, is the $M$. melodia; and of all the forms, except possibly insignis, this appears to be the most constant in the maintenance of its peculiarities over its wide habitat. In fact, so far as color goes, the variation appears to be scarcely noticeable; nor is the variation in size very marked. Such as it is, it appears to bear out the general rule of an average increase of size to the northward. This law, it may be remarked here, appears to be equally applicable also to all the other races. The general sameness in the topographical character of the eastern region and the resulting similarity of climate is doubtless the chief canse of the slight departure from type to be observed in melodia thronghout its range.

The Rocky Mountaius as far to the north as Oregon and to the south to our southern border, and the entire region west to the Sierra Nevadas, is occupied by the var. fallix. This bird is distingnishable from meloclia by a generally paler tone of coloration, by a decided increase in size, especially of wing and tail, and by a slightly longer and considerably more slender bill. The intergradation of this form with melodia is readily traceable and complete. From the very varied nature of the country occupied by fallax, it being broken up by lofty mountain ranges, and the ensuing differences of climate, considerable discrepancies might natnrally be expected in specimens of this race from different localities. Such proves to be the case; ant, in examining a large series, the attention is often arrested by some slight phase of color which is often so intangible as to practically elude definition, but which occasionally is sufficient to identify all the individuals from some one limited neighborhood. So frequently is this impression received, that it would almost appear as if each locality in the middle region furnished 
a trpe of its own, exhibiting the main charactcrs of fallax, but differing more or less appreciably. Thus the region of the Gila River affords a style of this race quite distinct from any other. The principal variation is scen in the very pale reddish tint, with scarcely a trace of dusky, which is especially noticcable in the streakings on the breast.

Another phase from Camp Harney, Oregon, is remarkable for its pale grayish tints. Such inter-races are doubtless the result of causes very local in their action, and are so slight and inconstant as to deserve nothing more than passing notice.

Reaching the foot-hills of the Sierras we find fallax beginning to assume new characters, and in the monntains and along the westeru foot-hills it finally merges into var. heermann. This form is characterized by a mnch darker shade of brown than either fullax or melodia, and by a bill much stouter than the former, but less robust than the latter. Hecmemmi has usually becu considered the Californiau song sparrow, the term thns including indiffcrently the birds both from the coast and the interior. But this is a mistake. The trpe now before me came from Fort Tejon, and it is in the interior only that the style to which this name was applied is met with.

Reaching the coast, another form is for the first time enconntered. This is the var. samuelis, of which the gouldii of Baird, as correctly determined by Mr. Ridgway, is the fall plumage. Hitherto some three or four individnals from the vicinity of San Francisco have been taken as representing all that was known of this race. Bnt nofewer than forty-six specimens are now at hand that agree well with the type, and are unquestionably referable here. In point of fact, it is samuelis alone that occurs in summer along and near the Californian coast, and nearly all published accounts of the habits, nesting, $\mathcal{E}$., of the song sparrow of California are to be taken as referring to it. This form rests chiefly upon its small size, it being by considerable the smallest of all the races, and the very dirk, almost black, color of its prominent streakings. But it is upon a basis of sizc alone that it can be separated from hecrmami, both agreeing in essential points of coloration. In fact, the question might well be raised whether it is necessary to recognize by distinct names two forms from this region. I have on the whole deemed it expedient to do so, as the difference of size, especially of bill, in specimens from the respective habitats of the two, as indicated, is pronounced and qnite constant, readily sufficing in the great majority of cases for their identification. Thus in over thirty specimens of heermamui from Stockton, Cal., kindly fnrnished by Mr. Belding, I find no marked differences, and all the individuals from the interior that have been examined, representing nuany localities, agree in large size, the average being considerably in excess of those frou the coast. A series of nine males, collected about Oakland, for the opportunity of examining which I am indebted to the courtesy of Mr. D. S. Bryant, of San Francisco, are similarly constant to the eoast trpe so far as size is concerned, but vary somewhat in coloration. The differences are chiefly as to the number and size of the black streakings below, two of the nine being the darkest, and, ou the whole, the most typical examples of samuetis I have secn.

Of the var. mexicana Ridgway, from Sonthern Moxico, little can be said, since the name rests upon a single specimen. This individual appears to be recognizable from the other races by its rather peculiar coloration, the streakings being very broad as well as black, aud by its small size. More specimens are necessary to determine its truc relations.

Var. guttata next invites attention. This is characterized by a darker, more rufescent type of color; the streaks on the dorsum are very indistinct, in some almost wanting. The bill is proportionately more slender than in any of the preceding forms.

The typical home of this varicty is the Columbia River region, coastwise. But long before reaching that point evidence is afforded br specimens of intermediate charaeter of the change to appear farther to the north. Thus fall and winter specimens from Nicasio, evidently reared farther north, are unquestionably iutermediate in eoloration between samuclis and guttata, while during the past season specimens were obtained by the expedition in Oregon npou the eastern slope, thus approximating the habitat of fallax, that are no less intermediate between that central region form and guttata, the two forms to the northward evidently passing, by insensible stages, into the latter:

Var. mina is simply guttata with the teudencies of the latter carried a step or two farther, with increase of latitude. The rufous of guttata in extreme cascs becomes a reddish sepia brown; the size is somewhat larger, the bill rather more slender. This is rufine as fonnd about Sitka and sonthward.

Upon certain of the Alaskan Islands occurs insignis. This gigantic sparrow is distinguished, in addition to its great size, by a much paler, grayer phase of color than its nearest geographical neighbor, rufinu. The streaks, instead of being nearly or quite obsolete, as in that form, are well defined and of an nuber brown.

Of insignis, Baird and Ridgway say: "Between $M_{\text {. melolia of the Atlantic States }}$ and $M$. insignis of Kodliak the difference seems wide, but the counecting links in the inter-regions bridge this over so completely that with a series of hundreds of specimens betore us, we abandon the attempt at specific separation." * * * It cannot be denied that the var. rufina from Sitka is nearer insignis, by many degrees, than the melodia of the East, aud, as has just been indicated, nothing is wantiug in the ehain of 
evidence to establish the connection between rufua and mclodia. But, while admitting the possibility that the relations between insiguis and rufina may be as close as that of races, $\pi \theta$ feel justified in asserting that the inter-gradation, necessary to establish this, cannot be shown from the material accumnlated up to the present time. Measurements appended below demonstrate that between the largest specimen of rufince in the collection and the smallest of insiguis there is a very wide gap. Nor does there appear to be any known law of geographical variation to acconnt for this.

As has leeen stated, and in conformity with a well-known law, increase of latitude secms to be accompanied by a general increase of size. But this fails of application in the case of insiguis, since Sitka, the typical locality of rufuu, is in the same latitude with Kodiak; while one specimen of rufiua, by no means the largest, is present from Litnya Bay, which is slightly farther north than that island.

Possibly its iusular habitat may be deemed sufficient to account for the marked characters of iusignis, since in their power of impressing peculiar features npon their zoological inhabitants, islands seem to have a law of their own.

Color alowe considered, although in this respect insiguis is well marked, the step from rufina appears inconsiderable when it is remcmbered the great change that has been. traced between rufina and melodia. The gap in size is much more important. Analogy in cases like the present has proved far from being always a safe guide, and since, by the test of inter-gradation, the only reliable one, insignis remains widely apart from the others, $X$ deem it far safer to allow insiguis to stand npon its merits until its claim to distinct specific rank be actnally disproven.

Measurenients are appended to show the average size of the various races; the largest and smallest individuals of each series are also given.

\begin{tabular}{|c|c|c|c|c|c|}
\hline - & Wing. & Tail. & Bill. & Tarsus. & $\begin{array}{l}\text { Depth of } \\
\text { calmen. }\end{array}$ \\
\hline 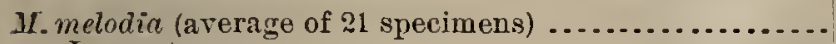 & 2. 60 & 2.80 & .46 & .83 & .30 \\
\hline 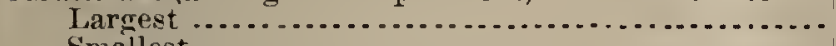 & 2.77 & 2.90 & .47 & .78 & .29 \\
\hline 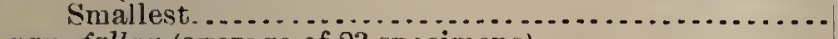 & 2. 32 & 2,60 & .45 & .78 & .30 \\
\hline 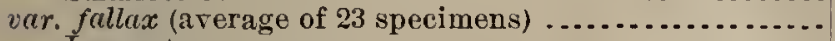 & 269 & 2. 94 & .44 & .84 & .25 \\
\hline 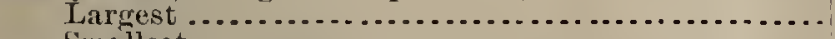 & 2.92 & 3.17 & .43 & .83 & .27 \\
\hline 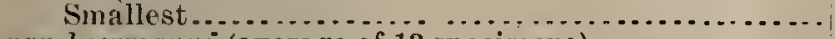 & 2.35 & 2.52 & .43 & .77 & .25 \\
\hline 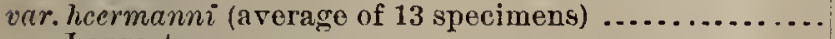 & 2. 61 & 2.82 & .45 & .84 & .28 \\
\hline 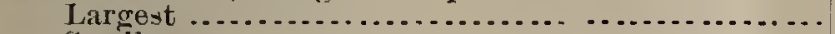 & 2.80 & 2.93 & .46 & .84 & .28 \\
\hline 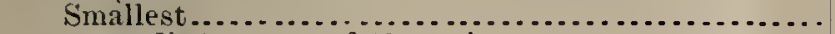 & 2. 45 & 2.80 & .45 & .83 & .24 \\
\hline 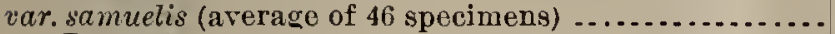 & 2. 41 & 2.48 & .45 & .84 & .26 \\
\hline Largest ....... & 2. 60 & 2.64 & .45 & .86 & .26 \\
\hline 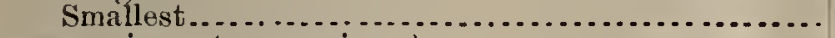 & 2. 13 & 2. 23 & .40 & .76 & .23 \\
\hline var. mexicana (one specimen) $\ldots . . . . . . . . . . . . . . . .$. & 2.52 & 2. 83 & .46 & .87 & .26 \\
\hline 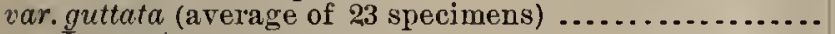 & 2. 63 & 2. 89 & .44 & .90 & .26 \\
\hline 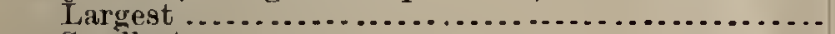 & 2. 78 & 3.14 & .46 & .93 & $\ldots \ldots . . .$. \\
\hline 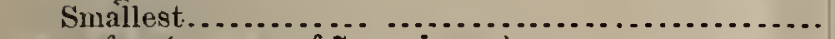 & 2. 42 & 2.59 & .45 & .83 & $\ldots \ldots \ldots$ \\
\hline var. rufina (average of 7 specimens) $\ldots . . . . . . . . . . . .$. & 2.78 & 2. 87 & .48 & .92 & .26 \\
\hline 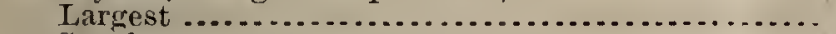 & 2. 96 & 3. 12 & .52 & .93 & .29 \\
\hline 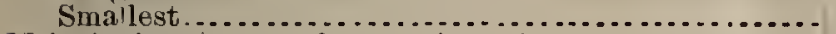 & 2. 61 & 2. 61 & .43 & .87 & .25 \\
\hline 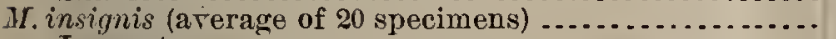 & 3. 26 & 3.39 & .61 & 1.07 & .30 \\
\hline 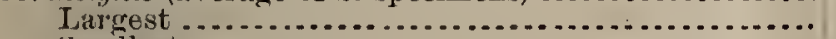 & 3. 40 & 3. 40 & .50 & 1. 13 & .32 \\
\hline Smallest..... & 3. 13 & 3.35 & .57 & 1.07 & .29 \\
\hline
\end{tabular}

M. melodia fallax (Baird). Rocky Mountain Sparrow.

This form was met with at several localities at the foot of the eastern slope, although it is along here that the change towards the heermanui type is first indicated; some specimens, indeed, from near Carson, Nev., appear to be referable to the latter variety.

\section{II. melodia guttata (Nntt.). Oregon Song Sparrow.}

If the song sparrows taken in Oregon at the base of the mountains in September are summer residents, as is doubtless the case, then the habitat of this race includes a restricted portion of the eastern slope. The specimens alluded to, from Warm Springs Agency and Crooked River, while not typical, are nearest to the above race. At The Dalles, ou the Columbia, in October, these birds were extremely abnndant in the hedgerows and brier-patches and along the small streams. At this locality the specimens were nearly typical guttata.

\section{Passerella Swainson.}

P. iliaea megaryncha (Bd.). Thick-billed Sparrow.

This curious sparrow is present along much of the eastern slope in summer, and probably reaches quite to the Columbia River. It was first seen near Carson, Nev., May 16 , being at this date found in considerable numbers in the wild-cherry brush along the cañon sides. It was apparently still on its way north, although Mr. Ridg- 
way states that the bird begins to move north abont the 1st of March. At a later date I found the birds quite common in the scrub on the top of Thompson's Peak, at au elevation of rather over 7,000 feet; and by the last of July fully fledged young were taken. The bird is eminently a mountain form, thick brush heing the prime essential to its choice of a home. It never, I think, descends into the low valleys, which, on the other hand, seems to bo preferred by the allied form sehistacea.

\section{HED YMELES Baird.}

\section{H. melanocephalus (Sw.). Black-headed Grosbeak.}

By May 15 this species was very numerons abont Carson, and appeared to be mating. Their frod at this season appears to cousist largely of the soft buds of various shrubs, especially of the willows.

How far north the species goes I am not aware, my note-book simply furnishing the statement of its presence in Northern California, but in much diminisled numbers. As it reaches Fort Steilacoom along the coast, it may attain a siuilar latitude in the interior. Its habits of nidification appear to be everywhere abont the same, and to correspond pretty closely with those of the rosc-breasted. Its architecture is of the simplest kind, the nest being made np of fine weed-stalks and similar light material, which are arranged in as circular a form as the stiff, myielding nature of the stems will allow. A lining of tine lootlets disposed in a shallow circular form completes the structure. This is almost always placed toward the extreuities of the lower limbs of trees, often overhanging a stream or deep ravine; more rarely the nest is placed on bushes.

Three egrs are occasionally laid, more isually two. They are light blue, irregularly spotted with redclisl brown and purple; usually, though not always, most thickly at the larger ends.

Considerable variation in size obtains between sets. Two measure $1.05 \times .73,1.02 \times .75$, and $.95 \times .6 \%, .93 \times .63$.

Cyanospiza Baird.

\section{C. amona (Say). Lazuli Finch.}

A conunou suumer resideut abont Carsou, but met with less frequently toward the north. Nevertbeless, Cooper reports it from Puget Sound, and Sucieley fonnd it in numbers in spring at The Dalles, Oregon. It was found by us to breed up to an altitude of $;, 000$ feet.

\section{Pipilo Vieillot.}

\section{P. maculatus megalonyx $\mathrm{Br}$. Long-spured Towhee.}

This, the only form of the towhee met with by us, is extremely numerous along the easter'n slope as high as the Columbia River. I fully agree with Mr. Ridgway that specimens of the I'ipilo found along the eastern slope of the Sierras are absolutely indistiugnishable by external characters from megalonyx. Thes appear to show no approach to oregonus, as that variety is illustrated by individnals from the northwestern coast. Nor have I been able to find in the habits, songs, and notes of the I'ipilo of the Sierras the striking peculiarities which had such weight with Mr. Ridgway as to induce him to identify it as oregonus, in the face of its apparent likeness to megalonyx in form and colors. On the contrary, the habits of the towhees, as they have fallen nuder my notice in the Rocky Monntains and in the Sierras, have appeared to be essentially the same. Mr. Ridgway was especially impressed with the fact that the mewing call, which all observers have attributed to megalonyx, was never heard by hinı from the form folnd near Carson. But a line in my note-book records the fact that this same mewing note was the only one heard by ne at this locality. Cooper, however, says that the call-notes of these two forms are alike, so that they have no distinctive value.

In the matter of birds' habits, differing circumstances of observation enter so largely as factors in the results obtained by different observers, that sucl evidence becomes, at hest, bnt a precarions means of discrimination, especially between birds closely related; as, for.instance, the members of the genns Pipilo. Apparent discrepancies in records are by no means alwass, perhaps, in fact, only in comparatively rare instances, attributable to inaccuracies of observation. But too often the fact is overlooked, or practically ignored, that in birds of the same species, at the same locality, and even at the same time, there may be a very marked diversity of habits, which is an expression of nothing more or less than individnal tasto or the result of quite adventitions circumstances. Sucl beiug the case, it is scarcely to be wondered at that in distant localities, where the observer is ever on the aleit for new facts, he shonld, not iufroquently, be misled into false comparisons by a note now to his experience, or some hitherto nnmoticed habit, which, perhaps, liad it been marked nearer homc, would bave attracted but casual attention. 
By the above, however, it is by no means intended to imply that such matters are not entitlerl to a place as aids to the proper nnderstanding of the relation of species to cach other. It is doubtless true that there is occasionally to be noticed certain changes in respect to the habits and songs of birds that accompany changes of locality, and which may furnish the first clew to external variation, in support of which they may be adduced as additional and valid testimony. But it is no less true that the pnrely individual variation in birds' songs and habits is often very great; in truth, such appcars to be the rule rather than, the exception; a fact which should be kept fully in mind when such features are male to enter into the question of specific or varietal distinctions.

I'. chlorurus (Towns.) Grecn-tailed Finch.

This sparrow is rather numerous in summer along the eastern slope, and reaches well into Oregon, if not, indeed, to the Columbia River.

Several nests with egrgs were found in July.

\section{ALAUDID E--Larks.}

\section{Erwiophila Boie.}

E. alpestris chrysolama(?) (Wagl.). Horned Lark.

The nswal central region form of the horned lark occurs rather numeronsly about Carson in summer upon barren pasture lands, sage brush, and alkaline flats, \&c. Its brceding range extcnds into Southern Oregon, and perhaps even farther northward.

It appears to me that the identity of this central region form with the chrysolema of Mexico is open to doubt and that its true place nay be elsewhere. Pending an examination of the question, however, I enploy the name in current use.

\section{ICTERID E-Orioles.}

\section{Xaxthocephalus Bonaparte.}

I. icterocephulus (Bp.). Yellow-headed Blackbird.

This blackbird is extremely abundant in all suitable localities along the castern slope far towards the Columbia River. In the latitude of Carson, it begius to breed somewhat before the middle of May, and by the 15th the tule beds, to which it. always resorts, will be found to contain nests in all phases of construction, while a few pairs, more ardent or enterprising than the rest, possess their full complement of four eggs. By the 1st of June nearly every nest contained eggs in various stages of advancement, while in not a few instances the young had already made their appearance.

The habit of colonization at this period is carried in this species to an extreme not observable in any other of the family, unless, perhaps, it be the tri-colored, as that bird is found in Southern California. Thousands flock together to form a happy, noisy community, their songs filling the swampy recesses with a confused and indescribable medley. Though by no means melody of a high order, they fall not unpleasantly upou the ear rightly attuned to bird music, when they are correctly interpreted as a mere rendering into andible sound of the overflowing jollity and good humor of the birds as they trill forth the notes in a happy-go-lucky sort of style from the swaying reeds.

The nests, wbile usually built well up on the reeds and fastened to the upper stalks, are not al ways so situated, but are occasionally, as was noticed in several instances at Washoe Lake, placel close to the marshy ground amoug the coarse grasses. When such is the case, the structure is very similar to that of the common red-wing under like circumstances. As the nests so placed were among the earliest found, it is probable that the more usual positions-high up on the reeds-is exchanged for one affording better protection and security for the early broods.

Dr. Colles tells ns that the males appear to desert the females during the period of incubation. But if this be a matter of observation, I think it is, to say the least, unnswal. I have found the males of this species as domestic in their habits and as assiduous in attention to their yonng as any of the family. It is trine, as observed by Mr. Nelson, that they are much shyer than their mates, the natural result of their more conspicnons colors and their distrust of danger on account of this. They are hence less often secn about the nest when it is disturbed.

\section{AGELAUS Vieillot.}

A. phoniceus (L.). Red-winged Blackbird.

An abundant summer resident along the eastern slope. More or less winter about Carson. 
A. phaniceus gubernator (Wagl.). Red and Black-shonldered Blackbird.

This form is less abmudant than the former as well as less generally distributed along the eastern slope. It appcars, as a lule, not to be found much east of this line, but it is reported from Camp Harnes. Oregon, hy Captain Bendire. It is noticcable in this connection that nowe of the specimens which are referable to this form from localities rast of the mountains represent it in its typical condition. Thus from the neighhorhool of Remo, Nev., at the eastern base of the Sierras, close to the border of Calfornia, we have a series of specimens the males of which have the crimson shonlderpatch bordered narrowly with light bufi, ench feuther of which border is bleck-tipped. Such individuals appear to be just abont half-way in development towards gubernator. It is interesting to mote that in this same locality the A. phenicens is also present (both breeding), and in as trnly typical dress as any where in the West. What proportion of individuals represent either form I cannot say, but believe that by far the largest percentage of the agelei here are pheniceus.

It wond thus appear as thongh the eastern blackbird extends to alont the line of the mountains unchanged ; that herc, the influences, as of climate, \&c., first begin to be fclt, which, only partially operative here, as they become intensified farther to the west resnlt in effecting the color change which is seen in typical gubernator. Iu this instance it would appear that the inflnences are sufficiently strong to affect only a proportion of individnals, which from obscure reasons are more susceptible to their workings; while the majority remain true to their type.

If, as is nsually nuderstood to be the case, color varieties are identifiable with certain limited areas of distribution, it follows that, as in the present instance, where the species inhabits contiuuonsly a widle region, the changes of environment are more or less gradual, and hence at certain points or along a certain line of distribution it is brought under conditions which are intermediate in character and force-a sort of neutral ground, as it were. From such regions come the specimens which, though often the cause of wo little perplexity to the naturalist from the difficulties in the way of their proper identification, are jet full of interest as furuishing indubitable proof of the intergradatiou of forms.

\section{StURxelda Vieillot.}

S. magna neglectc Aud. Western Meadow Lark.

Very numerons throughont this whole region.

Most of the nests discovered were arched over, thus conforming to the nsual plan of structure. In one instance the birds secmed to find the protection of the tall grass an ample safeguard, aud the nest was merely a flat open structure, with no attempt at a loof.

\section{ICTERUS Brisson.}

\section{I. bullocki (Swains.). Bullock's Oriole.}

Very numerous abont Carson and to the north wara along the base of the mountaius up to the Colmmbia River.

Begins to nest about Carson about the middle of May. After their arrival and during the early part of the summer; the orioles in this locality appear to obtain but very little of their subsistence among the trees, but resort in pairs to the hillsides, where on the ground among the sage bushes they apprared to glean a full harvest. The exact nature of this I did not asccrtain; it is probably though some species of worm or caterpillar that infests these plants.

\section{SCOLECOPHAgUs Swainsou.}

S. cyanocephalus (Wagl.). Brewer's Blackbird.

This blackbird is extremely abundant throughont this whole region as a stimmer visitant, while more or less remain through the winter.

Elsewhere, as in the Rock y Mountaius, I have found little disposition on the part of this species to gather in to comumuities at the brecding season. But in this region it is comparatively unnsual to find this blackbird breeding in other than large colonies, and I have found a dozen nests in the space of thirty or forty yards.

The eggs of no one of our birds arc subject to greater extremes of variation than those of the Brewer's blackbird. The differences are apparent not only in the amount of markings and their particular shade and character, but also iuclude much variation in size and shape.

\section{CORVID E-Crows.}

\section{Corvus Linuans.}

The question of the existence in the Pacific province of a species or variety of crow different from americanus and ossifragus is au iuteresting one, and a discussion of some 
of the joints involved will not be minteresting, even if an entirely definite and satisfactory conclusion respecting the relationships of the eastern and western birds be not reached. The name canrinus was proposed by Professor Baird in 1853 for a crow inhaliting the northwestern coast, and spccimens were cited from Puget Sound and Washington 'Territory. The characters of the snpposed species rested mainly upon its smaller size, together with certain pecnliarities of habits and notes. But from the first, the exact habitat and status of the new species appears to have becn somewhat doubtful, as at the time of clescription the above anthor included under americanus a number of specimens from contignons regions in California and Washington Territory, their distinctuess from the newly-described caurimus being assumed entirely on account of their large size, no other differences being discernible."

Since then the different habits and notes of the crows of the Pacific coast have been remarked in turu by nearly every observer who has visited that region, and appear to have been the main canse of the retention of caminns, either as a distinct species or a georraphical race of the conmon crow. In fact, habits and notes aside, no one appears to have been able to find a single tangible character by means of which the so-called camiuns was to be recognized. $\dagger$

'Thus Captain Bcndire, in his list of Camp Harnes birds, in which he gives canrimus as a "rare summer resident," renarks: "If it were not for their [that is, caurinus and americamis] totally different habits, I could see no really good reasons for separating this species."

Dr. Cooper seems to have been equally ronbtful of the relations of caurinus, and says, in "Birds of California," I am now satistied that there is but one species of crow on this side of the continent, and, if distinguishable at all from the eastern, it is by its smaller size, less graduated tail, more gregarious habits, and different voice." In conformity with this view, he inclndes in the habitat of cauriuns, not only the Pacific coast, but the region "east to the northern Rocky Mountains," thus entirely excluding americanns from the Pacific region.

Assuming the position taken by Dr. Cooper, that but one species of crow is represented upon the west side of the continent, I have becn able, after a carefnl examination and measurement of all the material aftorded by the Smithsonian collection, to verify the statement of the smaller size of the crows from the Pacific States only as a slight aterage, while among specimens from this region are some of the largest individuals I have seen-three, respectively from Tulare Valley, Sonthern California; Fort Crook, Northern California; and Camp Harney, Orcg., being matched in size by but few from the Eastern States. Nor do the strictly coast-inhabiting birds appear to be mnch, if any, smaller than those from interior districts. At least they are not consiantly so, since Dr. Cooper says "the smallest specimens I have seen were collected by Mr. F. Gruber on the west slope of the Sierra Nevada, about latitude $35^{\circ} 30^{\prime}$."

The shape of the tails of west coast specimens appears to vary in no particular from eastern, and I am finlly convinced that it is in vain to attempt to separate the crows of California, Nevada, Oregon, and probably Washington Territory from americanus by definite and reliable exterual character, the range of that species, therefore, in my opinion, embracing the Pacific as well as the Central region.

Bnt from the region north of Washington Territory the crows appear to undergo a general diminution in size, this being especially marked in respect to the length of tarsus; all the specimens at hand from the northwest coast (including one from Shoalwater Bay) agree in small size and extremely short tarsus. 'The general size of these birds is but little in excess of the a verage of ossifragus. But in no other particular are they like that species, being, in fact, save in the one particular of size, indistingnishable from eastern americamus. It was remarked by Professor Baird that the Corvide appear to form an exception to the general rule, and that "the same species in southeru localities are larger than those from points farther north." This statement will require qualification in the case of Corvus var. floridauns, which, while averaging in general size a trifle smaller than Northern-born birds, yet offers, in the increased size of bill and feet, a marked contrast to them. But as applied elsewhere in the United States the statement appears to hold good, and especially on the other side of the continent, where a decrease of size with increased latitude appears to be the rule. Possibly this simple statement of fact is all that the difference in size exhibited by the crows of the extreme northwest requires.

As considerable stress has been laid upon the different habits of caurinus it may be

* Prof. Baird further remarks of caurinus, after enumerating the points by which it may "readily be distinguished from the eastern fish crow," "it is so much like the corvus americanus as to be only dis. tinguishable by its inferior size and habits. Indeed, it is almost a question whether it be more than a dwarfed race of the other species."

tIn the recent work, "Birds of North America," by Baird, Brewer, and Ridgway, a further distinctive foture is assigned to caurimes, viz, the fact that the tarsus is shorter than the hill. But this statement resulted from an incorrect method of measurement, as Mr. Ridgway now informs ne, the tarsus being measured on its anterior surface, at the end of the feathering, instead of from the joiut, thus giving a length too short by a very appreciable amount. With the exception of the diminutive Mexican species (C. mexicanus) all the North American crows agree in having the tarsus longer than the bill. 
well to consider these briefly: and, first, it is to be remarked that nearly all the differences in habits and notes appear to apply as well to the crows found throughout California, Oregon, and Washington Territory as to those of the region to the north, while, as has just been stated, it is only in the lattor region that these are accompanied by a single salient character that will serve to ideutify the skins.

If halits be taken as the test, then all alike-those from the far interior of Oregon as well as from the coast, from California northward-must be held to be camims, although, as has been stated, a large proportion of specineus from Washington 'Territory sonthward absolutely differ in no particular of form or color from others from the Eastern States.

If, on the other hand, small size, as exemplified especially in the short tarsus, be held sufficient to characterize the race, then those only from north of Washington Territory are eligible to the name; and all from below, although sharing in the habits which have been held to distinguikh camiuns, must bo considered as americanms, notwithstanding, too, the additional fact that the measurements of some fer of the smallest of these latter approximate somewhat closely to Alaska specimens.

It may he added that while observers agree in the general statement of the possession by the so-called caminus of peculiar habits, the accounts of each vary as to the details, change of locality evidently producing a corresponding change in habits. 'Thus the domed nests, made of mud, which crurinus is said by Lord to build abont Sitka, differ entirely from those found by Bendire in Oregon, and by Cooper in California, which resembled the nsual style of the common crow. Nor clo the piscivorous habits of cauriums offer anything very distinctive, since they are shared by the common crow of Florida (ver. flovidamus), which there has many of the ways of the true fish crow (ossifiagus). About Washington, too, the common crow and fish-crow go in associate bands, and their uotes alone can be relied upon to identify them as they feed together along the river. As further evidence of the varying habits of the crows, it may be stated that in this locality the fish crow in turn often abandons its usual littoral haunts for the plowed fields and pastures of the interior. In fact, with birds possessing the omnivorous taste of the crows it appears to be quite a matter of accident that determines their hunting gronnds, those where food is most abundant and readiest at hand being the favorite; hence, of course, its nature raries indefinitely with locality and circumstances.

The alleged nore prononnced gregarions habits of caurinus, even allowing all that is claimed, are probably but the result of exceptional conditions, and appear to be carried in the northwest but little farther than is observable in the common crow at the East. Even on the Pacific coast the habit of breeding in colonies is far from universal. When such colonies are formed they are as likely to be the result of necessity as of choice. As, for instance, when favorable breeding grounds are scarce, a more or less extensive colonization must necessarily follow, which is less marked when other conditions prevail.

As to notes, this much may safely be stated, that some, at least, of the crows of the Pacific province have a note different from the usual one of americanus. As Dr. Cooper says, this "differs rather in tone than in character." In other words, it is the old-fashioned caw, but uttered in a different tone. In Southern California, near the coast, and in Oregon, east of the mountains, I have on many occasions heard this note, which has strongly suggested that of ossifragus, and which I then took for granted as belongiug to caurinns. Bnt in every such instance the well-known ringing caws of americanus were recognized from the same flock. Of six or eight individuals shot from these flocks all proved to be indistinguishable from americaums, and at the time I presumed the particular individuals of camiuns must have escaped me. Now, howerer, I feel tolerably well assured that all alike were amcricumes, the notes varying in individuals. Mr. Ridgway, on the other hand, informs me that in his experience in the Sacramento Valley, Nevada, Sc., he never heard any but the common note of americamus.

In conclusion, the general tenor of the change of habits of the Pacific crow, so far as auy are to be noticed, is in the direction of the fish crow (ossifiagus), and by at least one anthor the two bave been regarded as itlentical. But in the proportions of certain parts and in colors they are very distinct from ossifiagns, which may readily and infallibly be distinguished from the common crow from whatever locality by a number of wcll-defined characters.

At present I deem it, on the whole, advisable to recognize a race of the common crow from the extreme northwest coast, from Puget Sound northward, assigning, as characters, small size in general, aud especially a short tarsus, at the same time admitting the possibility that a larger series from the region in question, together with additionaI data concerning habits, \&c., may suffice to show its distinctness as a species. On the other hand, I am assurcd that no features are to be found attaching to the crows, either of the west coast or interior south of the above-mentioned point, that will warrant the maintenance of a nawe. Thes, at least, are americanns.

A series of nieasmrements is appendel below to attord means of comparison of the crows of eastern and western United States. 
AMERICANUS.

East of Rocky Mountains :

Average of 25 spccimens...

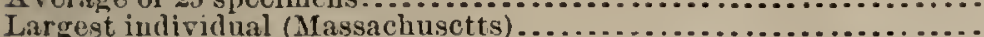

Smallest indiridual (Now Mrexico).

California and Orcgon:

Arcrage of $\varepsilon$ specimens.

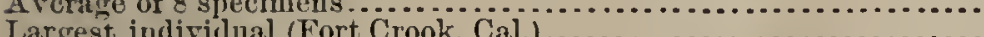

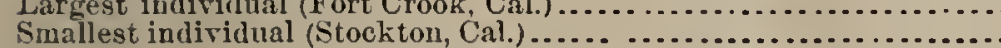

VAR. CAURINUS.

Puget Sound, Alaska:

A rerage of 7 specimens.

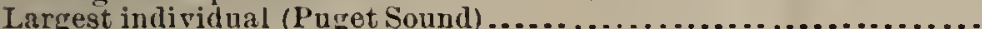

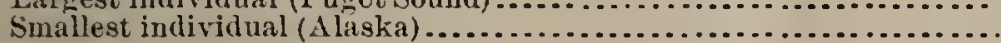

\begin{tabular}{l|l|l|l} 
Wing. & Tail. & Bill. & Tarsus. \\
\hline & & & \\
& & & \\
& & & \\
12.36 & 7.24 & 1.85 & 2.39 \\
13.00 & 7.45 & 2.00 & 2.60 \\
11.50 & 7.00 & 1.72 & 2.25 \\
& & & \\
11.78 & 7.21 & 1.78 & 2.30 \\
12.90 & 7.95 & 1.95 & 2.23 \\
11.00 & 6.80 & 1.60 & 2.23 \\
& & & \\
& & & \\
10.82 & 6.68 & 1.70 & 2.00 \\
11.60 & 7.25 & 1.88 & 2.12 \\
10.25 & 6.00 & 1.68 & 1.95 \\
& & & \\
& & & \\
12.05 & 7.12 & 2.04 & 2.49 \\
12.50 & 7.25 & 2.10 & 2.50 \\
11.45 & 7.00 & 1.93 & 2.42
\end{tabular}

VAR. FLORIDANUS.

Florida:

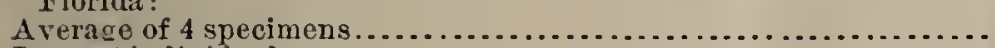

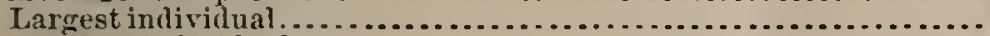

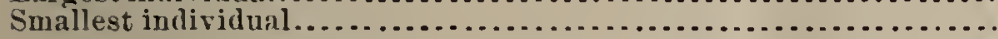

C. camirorus, Bartr. American Raven.

A resident species; more or less common everytwhere save in the higher mountain districts.

Pyramid Lake, Novada, forms a favorite resort for ravens during the summer, as the perpcindicular and inaccessible cliffs about certain parts of the lake present an abundance of sheltered ledges and cavities where they love to place their nests. I noticed that in one spot several pairs had built within the space of a few yards, a somewhat unnsual circnmstance, as ravens are not apt to be socially inclined at this period.

C. americamus, Aud. Common Crow.

Although by no means as generally distributed in the far West as in the Eastern States, the crow is yet found in probally each and all of the States and Territories west of the Mississippi. At all events it has not been wanting in any of those entered by our parties.

Whether its presence in the more remote Western States, as affirmed by many of the settlers, is a comparatively recent event, or whether the cultivation of the wilderness and the orchards and grain fields that have succeeded the advent of the pioneers have simply been the means of bringing the crow into direct contact with man, and so of waking its presence felt, are questions not easy to determine. I am inclined to believe, however, that the crow had made good a squatter's right to the conntry long before the date of the white man's possession, and to attribute its present unquestionably greater abundance in sections and territories where at first it was unnoticed to the fact of the concentration of the species into civilized districts, where its sagacity soon taught it a living was to be liad the easiest.

I lave never heard laid to the door of the crow the charge of any serious depredations on the corn and grain fields of the new Territories, and fancy that the kuavish tricks of its eastern cousins, that have earued them so bad a name, have not spread so far-possibly another reason for snpposing that the wcstern birds are not recent migrants from the east, else surely they had not left behind snch profitable tricks as pulling up newly-spronted corn and other devices of a like nature. Doubtless its natural food here is more abundant, and hence, the struggle for existence being less sharp, the crow finds it less needful to employ its wits to the end of getting a living at other folks' expense.

In Oregon, especially east of the mountains, crows are very numerons indeed, and I saw many large flocks on the various cattle ranges, as well as, later in fall, on the stubble fields. Meadowy pasture land and the vicinity of streams are the favorite resorts. The only difference between them and the "Jim Crow" of the east that I could detect was, at times, a difference in the cawing note, which, however, as stated above, seemed to attach only to individuals, the greater nnmber in the various flocks holding to the old-fashioned caw.

The "smell for gnnpowder" has evidently not been cultivated to the extent that is 
popularly attributed to the New England crow, and it proved a comparatively easy nuater to obtain specimeus. However, what crows, no matter where hatched, don't know about taking care of themsclves is very soon acquired, and a very little experience will be found to go a long ways with thcul. Naturally tle crow is no shyer than other large birds, and its extreme wariness at the East, instead of being an indication, as some writers are prone to construe it, of a natural trait, is simply due to persecutiou, and to it alonc.

\section{Picicorvus Bomaparte.}

P. columbianus (IVils.). Clarkc's Crow.

A constant and abundant resident of the pineries.

\section{GrinokitTa Maximilian.}

G. cyanocephalus (Maxim.). Maximilian's Jay.

A numerous and constant resident of the low ranges of piñou hills. Along unch of A route from Northern California lorthward along the base of the Sierra and Cascade Ranges this jay was entirely absent, the nature of the country being unsnited to its peculiar economy. At certain poiuts in the Des Chutes Basin, lowever, it was noticed iu great numbers. Here they were fceding upon a purple berry, the source of which I could not ascertain, but of which their crops were full, as well, too, upon the seeds of the yellow pine.

I am indebted to iny friend Mr. H. G. Parker, of Carson, Nov., for an account of the nesting habits of this jay iu his neighborhood. He informs me that late in March thousands breed upon the piñon hills, the colonies consisting of a variable number of pairs; occasionally isolated nests are foudd, but this appears to be rather exceptional.

Eggs were taken April 10.

The single nest he has sent for examination shows an uuexpected regree of taste and skill in the arrangement of the material, which is drawu very largely from the piñons. An external base of twigs, which appear to have bceu broken off from the ends of the branches, aftords firm support for the nest proper, which is a compact, deeply hollowed cup, wade of strips and shreds of bark from the sage bush. Finer strippings of the same with a few straws complete the lining.

The nest is usually placed near the top of the tree, sometimes near the extremities of the branches, occasionally close to the trunk. In auy event it is but a few feet from the ground, for the piñou rarely indeed attains a height of twenty feet.

The coloration of the eggs is very peculiar, and they are unlike those of any other jay that I have ever seen. 'They are greenish-white, marked with mmerons spots of brown and purple. As usual, this latter tint is due to the overlaying crust of shell. and is not, strictly speaking, a normal color. The markings are thickest at the greater ends, and tend towards aggregation in circles. A set of four eggs measure $(1.27 \times .87)^{2}$, $1.27 \times .88,1.27 \times .8 \%$.

\section{Pica Vieillot.}

\section{P. melanoleuca hudsonica (Sab.). Magpie.}

In the settled portions of Nevada and Eastern California of slight elevation, and especially in the wooded tracts that mark the courses of the streams, the magpie is a constant resident, and one which, from its size aud general couspicuousuess, is not liable to be overlooked. The thickets along the Carson River serve as favorite breeding grounds for great numbers of this species; in fact, I have never seen it more abundant: than here.

As noisy and as easily irritated into vociferous demonstration as is the magpie under ordinary circumstances, no sooner has the breeding season fairly begun tlian, under influence of the new feelings and cmotious that have sprung into existence, our magnie seems to lose its voice, and, from being one of the most garrulous of the feathered community, subsides into a very quiet and matter-ot-fact sort of individual, as if perfectly aware of the danger its usual boisterousness is likely to bring upon its home. To prove that this quiet demeanor is but a cloak assumed for a season, in obedience to an instinctive apprehension of danger, it is only necessary to approach with too curious eyes the nest of one of a community of pairs, especially if it chance to contain young. Under such circumstances the intruder will find himself the target for imprecations and auathemas, delivered with such unction and effect from a dozen angry throats, that he.will probably be glad to finish his investigations in a hurry and retire from the ground. In such a strait the pairs make common cause, and their audacity is in strong contrast to their usual wariness.

In the neighborhood of Carson every thicket of sufficient density to screen its bulky nest contains one, oftener several, of the structures, that aro so characteristic as to at once proclaim their ownershiv. 
While the manpie is to no inconsicerable extent a sharer in the natural ennuing, so justly attrilmecl to its relatives the crows, a fact in its history now and then comes to notice which roulil aplear at first thonght to negatire the possession of this trait: as, for instinee, the place and position in which their uests are oecasionally fonnd. Not only do these often seem to he imperiled by their proximity to the ground, being sometimes bnt a foot or two above it, bnt at times not the slightest attention will be paid to their concenlment. I have in mind a eertain point alon 1 the Carson Riser where some lead trees are fonnd, in which the magpies have nested for apparently a long leriod, ind where their nests are visible for a distance of many hnndred yarls. But. as il matter of fact the ergs or somng aro less liable to langer than would at first thonght ho snpposed, and donbtless experience bis tanght the birris this. In seleeting stieks and $t$ wirs for the onter nest the magpie, probably by design, chooses snch as, from their seragny, thorny uatnre, they are mabled to so fimly interlock that all ehance of forcible entryexcopt thongh the sulall aperture in the sirle left for the purpose is cut off, and evary foe provided against except man alone. Indeed, I hare myself, nore thau once, found it a far from easy matter to gain the interior through this thorny balriel.

So far as hmmans are eoncerned the magpies have but little to fear, as their marketable value, fortmintely for theinselves, anomnts to next to nothing. For, notwithstanding the fact that they may, when taken in hand poung, be readily tamer and, after the proper manipulation, be taught to talk, they are so noisy and theil dispositions so extremely mischievons, that a short experience nsually results in their being voted a uuisanee, and hence they stand in low favor. So a few taken for pets and an oecasional nest destroyed by nischievous boys smm up the dangers of the magpie's lousekeepingr.

The labor of this is pretty erenly divided. Upon the females devolves the main task of incubation, relieved $110 \mathrm{w}$ and then by their partners. The latter are away from lome most of the time busily occupied in foraging, since not only have they their own appetites to appease, but it is their dnty to provide for the females ongared in their enforeed duty. Upon the appearance of the young both birds share equally in attention to their wants.

Abont Carson the eggs are not deposited before the 1st of Mareh, but as late as the 12 th of May quite a number of nests were fonnd to contain fresh eggs.

\section{Cractua Swainson.}

C. stellerifrontalis, Ridgw. Blne-fronted Jay.

This form of the Steller's jay has been traced by the expedition from the Coast and Sierra Ranges of Southern California into the Caseade Mountains of Oregon, and so on ny to the Columbia River, at which point, however, the form does not cease, but continnes into Washington Territory.

As is rell known, this birl is represented in the Roeky Mountains by the longcrested variety, in which the streaks of the forehead are of a faint bluish-white instead of hlue, and the upper eyelid is conspicuonsly patched with white. 'Two speeimens collected at the base of the Cascarle Range are rorthy of note in this conmection, sinee, while they represent the normal frontalis type in everyother partienlar, both show unmistakable traces of this white patch, whieh in one is quite conspicnous; a bint, as it were, of the new character to be assumed farther to the eastward.

A description of the yonng in first plnmage is snbjoined.

Fivet plumage. - Above, dark plumbeons; head darker, with no trace of blue streaks on forehearl; wings blue, barred with blaek, as in adult; belly light blue; breast and throat plumbeous; ehin with light spaee.

\section{Cyaxocitta Bonaparte.}

\section{C. floridamus californicus (Vig.). Californian Ground Jay.}

Numerons in the brushy foot-hills to a considerable distance north of Carson, Ner. A single specimen, the only one seen, was taken at The Dalles, on the Columbia, October 4 , and it perhaps oecurs here and there over the intervening ground.

Nattall found the species common at Fort Vancouver, on the west side of the Cascade Monntains, in Oetober, and indicates its occurrenee as far north as the Frazer's River. This was in 18.34, and it appears to have escaped the observation of all the more reeent explorers of the same region. Recently Mr. C. Roop, of Portlanr, Oreg., informed me that this jay is abundant near the mouth of the Willamette River, in both Oregon and Washington Territories.

All the specimens we have seen from along the western slope, although not typical of the above race, are best referable to it.* 
A description of the first plumage of this form is added from a fledgcling taken at Eagle Lake, California, in July.

Prevailing color above, plumbeous brown; head with bluish cast; wings and tail l.lue, as in adnlt; below ashy white; feathers on throat and breast showing no traces of streaks; sides of head and an imperfect bar across breast dusky plumbeous. A conspicuous white line above and behind the eye.

\section{Perisoreous Bomaparte.}

\section{P. obscurus, Ridgw. Oregon Grä Jay, "Meat Bird."}

This bird was not recognized as distinct from the Canada jay ( $P$.ccuncdensis) unt il qnite recently, when Mr. Ridgway described under the above name specimens from Shoalwater Bay, and indicated Washington Territory, Oregon, and the northwest coast grenerally as its habitat. Mr. Riclgway, however, included the form under liead of canadensis, presuming it to represent the Pacific coast variety of that bird, as capilalis does the Rocky Mountain form.

A recent investigation, in connection with Mr. Ridgway. of a better series of specimens than was available when obscurus was described, leads to the belief that this form is entirely distinct from the Canada jay, its peculiaritics being of a kind not explainable upon any theory of geographical variation. As good descriptions of obscurus are found elsewhere, I need here merely allude to its chief distinctive points, viz: the conspicnous white shafts of the feathers of the back and scapulars, and the ashy white under parts, tending to brown only along the sides. In these particulars it differs conspicuously from the others.

During the past season obscurus was found to be a resident of the mountains from Northern California to the Colunbia River, its range being thus extended very materially. The joung in nesting plumage were taken near Camp Bidwell, California.

IIy specimens from the above region agree with the types in essential respects; in fact the only difference appears to be in regard to the amount of white, especially on forehead, it extending farther back towards the occiput than in the coast examples, while the general tints also are lighter.

A comparison of specimens of the Canada jay from Alaska and Maine reveals considerable difference. In fact, extreme examples of the Alaska type appear to show peculiarities of color sufficient to warrant their separation as a variety. Even, howerer, in the small series from the former region in the Smithsonian collection, there is a very noticeable amount of purely individual variation, and some specimens cannot be discriminated from Maine examples. So that; on the whole, I do not consider the difference sufficient to justify a new name.*

That the Rocky Hountain form capitalis intergrades completely with canadensis there can be no donbt, although typical specimens of capitalis ofter very tangible differences. In the northern Rocky Mountains, as in Montana, the peculiarities of this race very sensibly diminish, and the tendency towards the canadensis type is marked. From farther south and in its region proper, no specimens appear to be found which are not wholly characteristic of capitalis.

The following measurements express the variations in size between the forms:

\begin{tabular}{|c|c|c|c|c|}
\hline & Wing. & Tail. & Bill. & Tarsus. \\
\hline 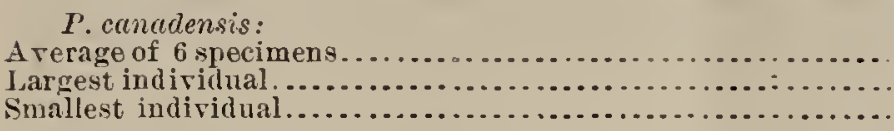 & $\begin{array}{l}5.61 \\
5.84 \\
5.33\end{array}$ & $\begin{array}{l}5.93 \\
6.07 \\
5.54\end{array}$ & $\begin{array}{r}.75 \\
.83 \\
.73\end{array}$ & $\begin{array}{l}1.35 \\
1.45 \\
1.33\end{array}$ \\
\hline 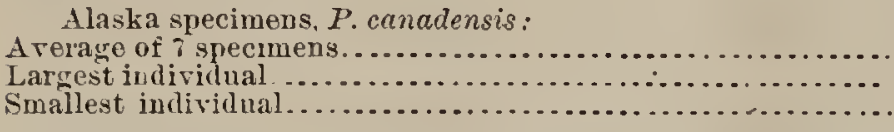 & $\begin{array}{l}5.43 \\
5.67 \\
5.10\end{array}$ & $\begin{array}{l}5.66 \\
5.65\end{array}$ & $\begin{array}{l}.77 \\
.85\end{array}$ & $\begin{array}{l}1.33 \\
1.40 \\
1.26\end{array}$ \\
\hline 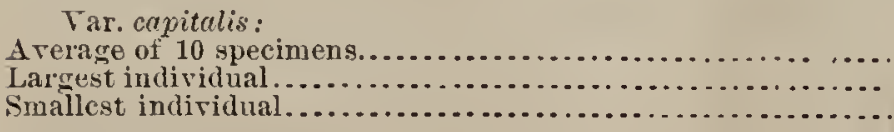 & $\begin{array}{l}6.04 \\
6.35 \\
5.72\end{array}$ & $\begin{array}{l}5.99 \\
6.12 \\
5.55\end{array}$ & $\begin{array}{r}.80 \\
.82 \\
.73\end{array}$ & $\begin{array}{l}\text { 1. } 36 \\
1.40 \\
1.34\end{array}$ \\
\hline 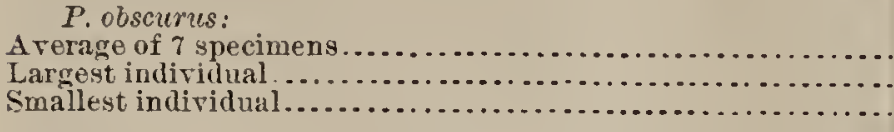 & $\begin{array}{l}5.53 \\
5.7 \\
5.23\end{array}$ & $\begin{array}{l}5.38 \\
5.58 \\
5.1 \%\end{array}$ & $\begin{array}{r}71 \\
.69 \\
.72\end{array}$ & $\begin{array}{l}1.31 \\
.321 \\
.261\end{array}$ \\
\hline
\end{tabular}

* Since the abore was written Mr. Ridgway informs me that he has giren the name fumifrons to the Alaskan coast form. 
As will he noticed, Alaska specimens appear to average considerably smaller than those from Maine.

Var. capitalis undergoes a decided incrcase in length of wing, without a corresponding increase in size of tail.

In obscurus the proportions of wing and tail are reversed, it being the only one which has the tail shorter than the wing.

Hubits. - As Northern California is reached, the Oregon gray jas becomes a familiar object of attention in the pine woorls, of which it is a constant resident. Along the Upper Des Chntes River the "meat birds," as they are suggestively termea by the hunters, were vers unuerons; so numerous, in fact, and so quietly persistent in their attendance abont the cook-fire, that they becime positive nuisances. When ther are inclined towards familiarity, they carry their boldness to a surprising extcnt. Every morning abont sun-up, from six to a dozen or more presented themselves in the trees orerhanging camp, and the momentary alsence of the cook fron his charge was construed as an invitation to the feast, and down they swonped upon the nearest morsel of food. Almost everything edible seemed to be acceptable, although their preference for raw meat was plainly evidenced. Finally, when the cook's patience gave out, the shotgun was bronght into requisition, which diminished the number, without having any visille, effect in checking the rapacity of the survivors. Several were readily caught hy means of a bent pin fastencd to a string and baited with scraps of vevison. They are not alwars by any means so bold as in this localite, and a clark form, risible for an instant as it flits noiselessly through the sombre pines, is of ten the only proof of the presence of the species.

I have always found the Rocky Monutain gray jay to be a very silent bird. But this species has'a variety of odd notes, a sort of squeaking, whining call being the most common. Croper also assigns this species a "considerable variety of song."

TYRANNID E-Tyrant Flycatchers.

Tyrannus Curier.

\section{T. verticalis, Say. Arkansas Fljcatcher.}

A very numerous summer resident. It was not observed by us farther north than Southern Oregon, but doubtless this was owing to the lateness of the season, as it was fonnd by Snckley at The Dalles, and eveu farther north in Washington Territory. The T. crirolinensis was not met with, but, according to Mr. Ridgway, occurs in summer in Western Nevada (Truckee Valley).

\section{Mriarchus Cabanis.}

M. cincrascens (Lawr.). Ash-throated Flycatcher.

Common on the foot-hills near Carson, but apparently a rare summer visitant farther north along the eastern slope. A single individual was seen at Hones Lake, California.

\section{SAYORRnis Bonaparte.}

S. sayus (Bp.). Say's Flycatcher.

Numerous along the eastern slope. This species is in the habit of building about barns and ontbuildings, in this respect being like the eastern Phœbe. A curioust nesting site sclected by one pair was a little niche in the sandy wall of a disused weil, and soine twenty feet or more from the top. The problem of getting the young up the old birds had set to solve.

The $S$. nigricans appears not to be present in this region, although it is common to the west of the mountains in Orcgon.

\section{Contorus Cabot.}

\section{C. borcalis (Sw.). Olive-sided Flycatcher.}

This flycatcher occurs in summer all along the eastern slope up to the Columbia River, and probably still farther to the north. It does not appear to be as numerous here as in the Rocky Mountains, or even in the region west of the Sierras.

C. vircus richardsoni (Sw.). Western Wood Pewee.

A common summer visitant of the mountains. A nest found June 26 contained two eggs somewhat advauced.

This flycatcher appcars to vary the position of its nest, sometimes building in the 
fork of a limb, at other times placing it on the broad upper surface-in other words, saddling it. The same variation iu plim is observable in the nests of our eastern pewee, although in both, the latter method seems to be the favorite.

The nest alluded to abore, as also a second fonnd. July :3, was sadd]ed upon the terminal fork of a cottonwood, and was similar to the usual styje of the eastern pewee, except that the exterior lacked the cnstomary sprinkling of lichens griven it by the latter bird. Instead it was dressed with shreds of a white cottony substance and gray fibrous bark, which scrved admirably to harmonize its tints with those of the ligbt bards of the tree, preciselp the same end being thus attained as effeeted by the other bird, each nsing the material best adapted to itsown case. It would indeed be a "blind "instinct that should induce the western pewee to alopt for its nest the cloak of lichens, the invariable and snccessful resort of its eastecu relative, an instinct that would prove fatal to the safery of its home, and only serve to insite the very danger of conspicnonsness which it is its chief object to avoid. The contrast of differing means to the same end which is displased in the architectnre of these two flyeatchers is one of many equally rood illnstrations which might be cited to prove the presence in birds of a something higher than were hereditary instinct, and shows that only by granting the existence of an amount of reasoning power can we explain the readiness with which a species alapts its existence to new conditions, and the fertility of resonrce which pronipts the choice of means to a necessary ent.

\section{Enpidonax Cabot.}

\section{E. trailii, Aud. 'Traill's Flycatcher.'}

Western specimens of this bird have usually been considered to represent a lightcolored race, and have fonnd mention nuder name of var. pusillu. I think Mr. Ridgway is correct in the view recently expressed,* and that western and easteru birds do not differ sufficiently to warrant their separation.

The pusillus of Swainson was accepted bp Professor Baird as applying to the western bird, but apparently with some doubt, as Swainson's description applies almost equally well to minimus. I prefer, therefore, to fall back upon the trailii of Auclubou, inclnding nuder this name both eastern and western birds.

The Trails flycatcher is a numerous summer resident of the eastern slope, well up into Oregon. It loves to frequent the willow thickets along the streams, evon follow ing thew to a high elevation in the mountains.

\section{E. obscurus (Sw.). Wright's Flycateher.}

Apparently rather uncommon as a snmmer inhabitant of the mountains, where only it is found at this season. It appears in summer never to frequent the same situations as the preceding bird, although the two may inhabit the same general locality. Thus, the borders of a strean which meanders through an alpine valley, and which is hedged by willows, will be found, a]most to a certainty, to be inhabited by the little flycatcher, while the present species never intrudes on the domain of this bird, but is contented with the lillsides above, where it lives under the pines and among the chaparral.

It would be interesting to study out the probable causes which thus lead two species so closely allied as these two flycatchers, with the same general habits and economy, with precisely the same method of captnring food, and living withiu sight, as it were, of each other, to so maintain their own preserves as never to clash with each other. A possible explanation suggests itself in varying tastes as to food, since it is probable that each locality differs enough in the character of its plants to harbor different kinds of insects, and hence to furnish each species with its own particular bill of fare.

A nest found June 22 contained four fresh eggs. These are rellowish-white, and unspotted. The nest was an extremely neat, pretty structure, composed externally of strips of white bark, with an internal lining of fine grasses and feathers. It had a depth of two inches, and an internal diameter of the same. It was singular]y exposed to view, being placed on an open bnsh on a hillside, where it was overshadowed by large pine trees.

The E. hammondi is said to also occur along the eastern slope, but I did not meet with it.

\section{CAPRIMULGID E-Goatsuckers.}

\section{Cirordeiles Swainson.}

\section{C. popetue hemryi, Cass. Western Night Hawk.}

An extremely abundant snmmer visitant through California, Oregon, and into IVashington Territory.

\footnotetext{
* Ornithology of the Fortieth Parallel, page 539.
} 
Several sets of ergrs were found, which seemed to have been deposited on the gronnd hap-hazard, with little or no attention to special locality.

Antrostonus Gould.

A. muttalli, And. Nuttall's Poorwill.

In the neighborhood of Carson the poorwill arrives from the sonth in the early days of May. It soon becomes generally and commonly distributed over nearly all the region enlbraced in the present report, being scarcely less numerous towards the north. Both Cooper and Snckley note its presence in the portions of Oregon and Washington Territory, east of the mountains, and indicate negatively its absence to the wcst.

TROCHILIDE-Hnmming Birds.

Stellula Gould.

S. calliope, Gonld. Calliope Humming Bird.

The range of this diminntive humming-bird is now pretty well made out. It has kong been known as a resident of the west coast, and there extends over much of California, Oregon, and Washington Territory, where in summer it is confiner to the mountains. To the eastward its summer habitat appears to be in general limited by the eastern slope, along which, in Nevada, California, and Oregon, it was found by our parties to be very numerons. In fall, at least, it reaches as far into the middle region as the East Hnmboldt Monntains, where fonnd in $\Lambda$ ugust by Mr. Ridgway. New Mexico and Arizona, as determined by our parties, complete its limited range in the central regions and likewise its known dispersion within our limits. It may breed in the latter Territories, as specimens were obtained in July. That it does so along the eastern slope there is no possible donbt, as about the middle of June, in Eastern California (Honey Lake), I often saw the females most busily at work gathering stores of down from the willow catkins, then hanging full, to weave into nests. I was left to conjecture that the location of these was in the high branches of the firs and other evergreens, as I failed to discover a single one, which conld hardly have been the case had they been in positions at all accessible.

The males were at that season verr restless and wary, aud to procure specimens proved no easy matter. 'The flower which here is most resorted to, not alone by this but by other hummers, is a speeies of Castilleia which is found along the banks of most all the nonntain streams. Wherever these blosoms are numerous, the hum of wings of these busy little pilferers as they dart to and fro is constant.

Humming-birds have, however, in this section, another and less nsual source of food supply, to which ny attention was attracted while in the monntains near Camp Bidwell. For several of the early honrs of morning I noticed that the humming-birds hovered about the upper branches of the firs and spruces, precisely as if feeding, to the entire neglect of the flower-bordered streams which occnpied their attention later in the day. $\Lambda$ s this is the time when they are hungriest, I conld only acconnt for their actions on the supposition that they were feeding upon "honey dew." As this mas not be familiar to all my readers, I will state that it is a sweet saccharine substance that is deposited upon the foliage of trees and shrubs in many localities of this region by certain small insects, the plant-feeding Aphides. It is of ten found in considerable quantities, so considerable in fact that in some places, as I was informed, the Indians collect it by threshing the plants after the sun has evaporated it into a sugar, and make use of it as food. That it is sweet and palatable, I myself can testify, and donbtless as much so to the delicate taste of the humming-birds as to the hnman palate. In early morning, before the sun's rays have evaporated it, "honey dew" is found in a semi-liqnified state, and then would be as easily managed by the brush-tipped tongnes of the birds as the nectar of flowers. Withont doubt, too, the birds secnre many small insects which resort to feed upon this snbstance.

Here I wish to notice what I believe was an error of identification on the part of Dr. Cooper when he mentioned the broad-tailed humming-bird ( $S$. ptalycercus) as common at Lake Tahoe in September.* This is quite out of the area of the known distribution of that bird, which is distinctively a central region species. Slellula, on the other hand, is a common summer resident of this region and could scarcely have been overlookerl. It is not, however, mentioned by him from that locality. Hence I infer that his specimen of supposed platycercus was really the Stellula, more especially becanse he appears to have been in donbt, and states that at first he supposed the species to be $S$. rujus. In this latter supposition he may have been correct, bnt as, farther on, when speaking of the Stellula as seen in the Cascade Monntains, he says he there mistook that species for the young of $S$. rufa, we may presume his mistake to have been the same 
in both instances, and that the Lake Tahoe birds were the Stellulo, as the Cascade Mountain birds proved to be. It is to be remarked that the young of several of the hummers are really so nuch alike, especially those of calliope and rnfus, that a very careful comparison, which is rarely possiblo in the field, is necessary to distinguish them.

\section{Trochlus Linnæus.}

T. alexandri, Bourc. and Muls. Black-chinned Humming Bird.

This species appears to be a by no means common summer resident along the eastern slope, and to have there a limited distribution. It was observed and specimens wero procured in June in Eastern California along Honey Lake. Farther north, in the mountains near Camp Bidwell, the species was present in July.

\section{SELASPHORUS Swainson.}

S. rufus, (Gmel.). Rufons-backed Humming Bird.

This hummer is probably rather local as a summer resident of the eastern slope. In the summer of 1876 I did not find it brecding in Eastern California, althongh plentifnl enough there in fall. It appeared to be rather nnmerous in summer near Camp Bidwell.

\section{ALCEDINID AE-Kingfishers.}

C. alcyon (L.). Kingfisher.

Ceryle Boie.

Of common occnrrence on all the fish-stocked streams.

PICID E-Woodpeckers.

Hylotomus Baird.

H. pilcatus (L.). Pileated Woodpecker.

The "log cock" was not noted by our party at any point along the eastern slope notwithstanding that the heavily timbered mountains would appear to favor its pres ence. On the Columbia, to the west of the divide, it was said by the lumbermen to be a numerous and constant resident. I shot a fine male, the only one seen, at the Cascadcs, in October.

Picus Linnæus.

P. rillosus harrisi (Aud.). Western Hairy Woodpecker.

Numerous as a resident of the pineries.

P. pubescens gairdneri (Aud.). Western Downy Woodpecker.

Along the eastern slope, as everywhere throughont the middle region, this is a rare species, and but a single individual was seen-in Chewaucan Valley, in Angnst.

P. albolarvatus (Cass.). White-headed Woodpecker.

This woodpecker appeared to be less common everywhere along our route to the north than in the pineries immediately west of Carson. It occurs nevertheless here and there as a residerit.

Picoides Lacépède.

$P$. arcticus (Sw.). Arctic Woodpecker.

A rather common and constant resident of the pine woods from Carson northward iuto Oregon.

\section{Sphiyrapicus Baird.}

S. varius muchalis (Bd.). Red-naped Woodpccker.

This middle rcgion form extends across from the Rocky Mountains, and occurs in summer along the castern slope. Beyond this we have no evidence of its presence, it being replaced upon the west coast by the following bird.

Mr. Ridgway alludes to the fact that in the region between the Rocky Mountains and the Cascade Range specimens of this form give evidence, by the admixture of rcd in the black auricular stripe, the black pectoral collar, and in the white area surround- 
ing it, of the eliange soon to resnlt in the variety ruber, in which these parts are red. Two males, however, taken in the Warner Monntains, Northern California, show no snch tendeney, int, on the contrary, are not distingnishable from Rocky Momntain specimens.

S. varins ruber (Gm:). Red-breasterl Woorlpecker.

Somewlat to my surpurise I was able to obtain no evidence that this variety snmmers along the eastern slope, and an compelled to believe that it is only fomnd here in the character of a fall and winter visitor.

S. thyroideus (Cass.). Brown-headed Woodpeeker.

Of rather frequent ocenrence all through the monntains.

\section{Asyindesmus Cones.}

1. torruatus (Wils.). Lewis Woodpecker.

Towhere in its wide range is this species more abundant than at the base of the eastern slope, throngli Nevala, California, and Oregon. It was seen at The Dalles dnring the last of October, and necording to snekley it remains here during the winter

\section{Colaptes Swainson.}

C. auratus mexicanus (Sw.). Red-shafted Flicker.

An abundant and widely-distributed speeies. The birds of the eastern slope appear to be the typieal mexicanus, and I have never scen a speeimen from this region showing intermediato charaeters. In the Saeramento Valloy and about San Francisco such specinens are comparatively eommon, and the manner and degree in which individuals assnme the eharaeters of either raec vary indefinitel $y$.

\section{STRIGID $\mathrm{E}-\mathrm{O}$ wls.}

\section{STRrx Linnæens.}

\section{S. flammea americana (Aud.). American Bam Owl.}

Thomgh a very eommon inhabitant of California, cspeeially in the southern portion, and extending, aceording to Cooper, as high as the Columbia River, this owl appears to confinc its lange, so far as this region is concerned, to the country west of the Sierras, and it does not appear in ans of the scctional lists east of that range between Kansas on the east and Arizona on the south. That it does ocenr on the east side of the Sierras I obtained ample proof dhiring the past season. Near the Madeline Plains in Eastern California I fonnd scattered feathers of barn orvls, indieating that they inhabited the thickets along the streams. At Camp Bidwell it seemed to be a tolerably common species, and on several oecasions individuals were started up as they were roosting among the tangled willows. 'This was late in September. It also appears to be of at least oceasional occnrrence in Western Nevada, and Mr. H. G. Parker has information of the capture of a speeimen or specimens near Carson.

It is one of the most strictly nocturnal of the family, and as its diurnal retreats are usually of the most inaceessible eharaeter, the bird readily eludes casual observation. Hence it is likely to prove to be nore widely diffnsed in the interior provinee than we are at present aware.

\section{Otus Cnvier.}

O. rulgaris wilsonianus (Less.). Long-eared $\mathrm{O} w \mathrm{l}$.

Nunerous in the thickets of the lowlands, where it is resident throughont the year.

O. brachyotus (Stev.). Short-eared $\mathrm{O}$ wl.

This owl was found to be eommon in the sedg. marshes abont Warner Lake, Oregon, and donbtless inhabits similar loealities thronghout Eastern California and Nevada.

\section{Bubo Dumeril.}

\section{B. virginianus sub-arcticus ( $\mathrm{Sw}$. ). Western Grcat Horned Owl.}

Often heard in the monntains, where it is resident. Tro individnals of the many seen were obtained in the Cascado Mountains. They represent the eommon interior type. 


\section{SPEOTYTo Gloger.}

S. cumicularia hypoga (Bp.). Burrowing Owl.

Numerous in all suitable localities throngh this region.

FALCONIDA-Hawlss, Eagles, ote.

Circus Lacépède.

C. cyaneus hudsonius (L.). Marsh Hawk.

Very numerous in every snitable locality.

\section{Acciritrer Bonaparte.}

\section{A. fuscus (Gm.). Sharp-shinned Hawk.} ber.

A single specimen only of this hawk was obtained, at the Columbia River, in Octo-

A. cooperi (Bon.). Cooper's Hawk.

Appears to be much more numerons iu this region than the preceding. Seen on the Columbia in October.

Astur Jarrl, and Selby.

A. atricapillus (Wils.). American Goshawk.

This fine hawk was scen at several points along the Cascade Mountains in Oregon, where it, withont donbt, breeds.

I harl very little chance to observe its habits; probably they lo not differ essentially from those of its smaller relatires. One that I shot on the Williamson's River was in hot clanse of a kingfisher, which he doubtless would have seized in another moment. Another, on the same river, was noticed chasing a night heron. The attack was persistentily kept up, bnt evidently with no intention on the part of the liawl of making the heron his prey. Forcing the heavy-winged heron into the open, the liawk wonld close in and apparently give the nngainly birl a buffet with his wing, which each time prodnced a lond and discontented sqnawk. It occurred to me, as a possible solution of the motive of the hawk, that he intended to force his victim to throw up any fish it might have secured, and so furnish him an easy diuner.

\section{Falco Linnæus.}

\section{F. lanarius polyagrus (Cass.). Prairie Falcon.}

A widcly-diffused species, and common in certain localitics of this region, as near Camp Bidwell.

In the fall its habits as truly entitle it to the appellation of "duck lawk" as its relative the $F$. anatum. The latter, although not falling nnder our observation, certainly occurs in this region, but by no means as commonly as its ally.

\section{F. richardsoni. Richardson's Faleon.}

The presence of this falcon was noted in several localities in Oregon and Northern California, and two specimens in immature plumage were taken.

\section{F. sparverius (L.). Sparrow-Hawk.}

Very common thronglont this whole region.

The west sicle of Chewancan Valley bar snffered severely from a visitation of that scourge of the western farmer, the grasshoppers. Here in Angust the sparrow-haw-ks had assembled in hundreds and were holding bigh carnival, and althongh in instances like the present their mumbers prove wholly insufficient to copo against the vast 11 yriads of these destructive insects, yet the work of the sparrow-hawk is by no means so in. significant that it should not be remembered to his credit and earn him well-merited protection. His food consists almost entirely of grasshoppers when they are to be had, and as his appetite appears never to become satiated, the aggregate in numbers which are annually destroyed by him must !e euormons.

\section{Buteo Cuvier.}

\section{B. swainsoni (Bp.). Swainson's IIawk.}

Very nmmerous in summer in the low partially-wooled comntry uear the mountains. I noticed more of these hawks in Northern California than farther sonth, but this in- 
erease in numbers may have bcen only apparent, and due to their concentration as fall approached.

B. borcalis calurus (Cass.). Western Red-tailed Hawk.

Nnmerons througliout all tine heavily-wooded portions of the region.

\section{Arcinbuteo Brehm.}

A. ferrugineus (Licht.). California Squirrel Hawk.

A lrawk was seen in Northeastern California which I believed to be of this species.

A. lagopus sanctijohamnis (Grnel.). Rough-legged Hawk.

Common in fall in marshy localities.

Aquila Brisson.

A. chrysä̈tos canadensis(L.). Golden Eagle.

Occurring more or less mnineronsly among the mountains.

Halialitus Savigne.

H. lcucocephatus (L.). American Eagle.

This eagle may fairly be said to abound on certain of the mountain lakes of this region, Eagle Lake indeed receiviug its name from the number of these birds that inliabit its shores. Rarely distnrbed, they are much less shy than nsnal, cvidence of this fact bcing apparent in the accessible situations which their nests occupy. Several were noticed in the splintered tops of pines, the low heights and convenient branches of which placed them within easy reach.

One nest that I risited as late as July 10 contained two young, still unable to fly, though in size fully grown.

Alonir the Columbia, eagles are so common that they scarcely attract attention. Here they are nsuful as scavengers, and dead and dying salmon form a very considerable portion of their fare.

\section{Pandion Savigne.}

P. haliaëtus carolinensis (Gmel.). Fish Hawk.

Present on nearly all the streams and lakes that furnish fish. Extremely abnndant at Klamath Lake.

\section{CATHARTID A-American Vnltures.}

\section{RHINogryphus Ridgw.}

R. aura (L.). Red-headed Vultnre.

Generally distribnted; in some localities, as near Honey Lake, California, very numerous. Not seen at the Columbia River in October. Nor was the Californian vulture (Pseudagryhus californianus) observed along the river, although, jndging from the accounts of Cooper and Suckley, it formerly periodically visited its shores, attracted thither by the dead salmon, which, dnring the "run," often line the banks. The ac. connts of these anthors date back to 1854, and since that time the numbers of this hure vnlture have been so diminished by the use of poison, intended to kill off wild animals, that it is now in comparison almost extinct, and the sight of a California vulture is at present a rare event in localities where a few years ago it was very nnmerons.

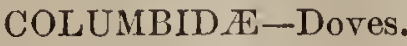

\section{Zenaidura Bonaparte.}

Z. carolinensis (L.). Turtle Dove.

Arriving in the vicinity of Carson abont the 1st of May, the "doves" soou become extremely 11 unerons, not only here but all along the eastern slope, far up into Oregon and Washington Territory.

By the gane law of Nevada this species is exempt from protection at any and all seasons, and as it is abont the only bird here that affords wing-shooting, it hence, in the ncighborhood of the towns, receives consiclerable attention at the hands of the gunners, especially during the early portion of its visit in spring. 
It begins to nest about the unidlle of May, and then its persecution perforce eeases, since it no longer resorts to the stubble-fields and pastines for food, bnt, having paired, retires to the hills, where it is out of reach.

The numbers killer, although in somo sections very great, appear to have 110 visible effect in dinimishing its abmolance.

It migrates south early, and but few are to be found in Nevarla by the ond of Aumist. As late as the 231 of Septemher I noticed a few young hirds, probably tho late second broods, still lingering abont the stubble along Crooked River, Oresron.

\section{Columba Linnæus.}

\section{C. fasciata (Say). Band-tailed Pigeon.}

At The Dalles I caught a glimpso of a solitary individual which I identified as this species. It is said by both Cooper and Suckley to be abnudant to the west of the monntains, and doubtless wanders across tho range with greater or less fiequency, the abundruce or scarcity of food, especially acorus, having much to do in determiningits presence or absence in a region. Dr. Nowberry spoaks of it as occurring at The Dalles in fall.

\section{TETRAONIDA-Grouse.}

\section{Canace Bonaparte.}

\section{C. obscurus (Say). Dusky Gronse.}

The "blue grouse," which is fonnd in the Sierra and Cascade Ranges, at least along their eastem slopes and as high np as the Columbia River, is the typical mirldie regiou forn, obscurus.

The mountain forests, especially those composed largely of firs and spruces, abound with this fine game-bird. Several broods of young chicks were fonmd about the widdle of June.

First plumage of young.-Feathers of the back and wings (except primaries) with broarl central line of white, and marked transversely with spots and lars of black and rufous brown; throat and belly brownish white; breast and sides of body profusely macnlated with black.

\section{Centrocercus Swainson.}

\section{C. urophasiams (Bр.). Sage Hen.}

Numerons as is this species in many portions of the Rocky Monntain reginn, it appears to bo even more abundant in the sterile tracts that lie just east of the Sierra Tovarla and Caseade Ranges, where it is gcuerally diffused in all snitable localities from a point well up towards our northern bonndaries to as far sontli as the Mojave River where reported by Cooper. Tho most sonthern print at which the bind was encountered by our parties was about fifty miles sonth of Carson, as indicated by Lientemant Macomib. Somewhat to the north of here it begins to be very numerons, and in certain localities, as near old Camp Warner, Oregon, its numbers are simply astouishing. A day's ride through this section in almost any dire tion will reveall waud after band, many containing numerons individuals.

During the summer it inhabits preferably the low monntains and hills, which are only saved from utter barrenness aud destitition ly a growth of sace or brush of sinilar kind and a scanty covering of coarse grass. The little valleys intervening contain occasional springs, which with the suromuding plats of green verdure form little oases, and these are the centers around which congregate, at least thrice a day, all the sagehens within a considerable area. When making the nsual night's camp wo have often started np fifty or more of these big crronse" almost within stone's throw of the soli1ary pool of water. At middar, too, locks of old and solug love to come in froll the sterile tracts where they have becn feeding, to drink and bathe and repose in the grateful shade which they fiud only in such spots.

After the foung are able to run abont, I believe the nother bird assmmes sole charge over them, and that the old cocks assemble into hands and remain by themselves. I have on several occasions seen a dozen or more old males, lean in flesh aud with plun1agc soilcd and worm, thus associated. The old cock, under such circumstances, is a wary bird and knows well how to take care of himself. Littlo need, however, has he of his cantion, since his tonglımess and general unsavoriuess will be likely to canse anyone who once has nuade his acquaintance on the table to give him a wide bertl in the futnre. But it is some time ere the young learnfully the nccessary lesson of caution and sclf-depecndence, and even after they havo becomo almost fully grown they unay firequently be put up one by one and killed without causing the dispersion of the rest of the band. 
In fact, the tanencss of the sage hen when, say, two-thirds grown, is occasionally so remarkable as to alplear searcely credible. As an instance, I remember on one oceasion, when in one of the willer districts of Oregon, pointing ont a pair to a comrade. who harl expresserl a desire to try a shot on the wing at this, to him, new game. Unscrecened by cover, the pair permitted him to approach within a dozen feet or so, regardiug with mild wouder his demonstrative motions, and cven failing to take alarm when clirt and peblules were tossed at them. With the remark that thej were too slow game for him, my disgnsted friend left them to resmme their picking anong the herbay, which thay did while we were still regarding them.

Duriug the unonths of June, July, and August the soung are very tender, and, if properly attenderl to by being drawn as soon as shot, are fair eating, but this is the limit of praise that my taste, at least, will permit me to bestow.

\section{Pediccetes Elliott.}

\section{P. phasianellus columbianus (Ord). Southern Sharp-tailed Grouse.}

This grouse appears to be entirely absent from Eastern California and Western Ncvada, cxcept in the upper districts. About Camp Bidwell, Cal., the "sharp-tails" are sufficicntly mumerous to afford excellent shooting, and good bag; may be made there. rartlier north in Oregon, and especially on the grassy plateaus that border the Columbia River and on the rolling hills for a hundred miles south, it is extremely abundant. Most of this section is quite nncultivated, and the grouse live among the dry bills and get fat npon their natnral foorl of seeds, berries, and insects. They descend regularly in to the valleys, as well to get water as to roost in the brush at night. A stubble-ficld of wheat is sure to at tract them in great numbers, especially towards fall, and they seem to prefer this fare to aught else.

I have never had any cxperience in the field with the true prairie chicken (C. cupido), lut, judging from the written accounts, the general habits of the two birds are extrenely similar.

\section{Bonasa Stephens.}

\section{B. umbellus sabinii (Dougl.). Red Ruffed Grouse.}

This form of the ruffed grouse oceurs abnndantily along the eastern slope, although perlials not mintil Oregon is entered. At lcast, Fort Klamath was the tirst point at which I obtained undeniable proof of its presence.

It may here be remarked that the gronse of this region, while referable as above, do not typically represent the variety sabinit, which reaches its maximum of clevelopment, as indicated by deptli of color and rediess of tint, only on the Pacific slope.

In the dense coniferous forests that border the Columbia, as it passes throngh the Cascarle Mountains, these grouse are found in very great abundance, the almost inpenetrable undergrowth of deciruous bushes, with their nutritious fare of buds and berries, greatly fivoring its presence, as offering both food and cover.

It is scarcely necessary to add any details respecting the habits of this bird; for in this remote region it appears the exact counterpart of the familiar partridge of New England. Trie, they are here very tame and almost devoid of fear of man; so tame are ther, in fact, that without a dog it is well nigh nseless to attempt their pursuit. Provided with almost any sort of a cur that will run tbrough the bushes and bark when the birds wing their way to the nearest tree, which they will invariably do when started, alunost any desired number nay be potted ; for "pot hunting" it is, and nothing elsce.

Inch the same statement may be male of the conduct of the ruffed grouse in the more remoto Now Eugland districts, as iu some unfrequentéd parts of Maine; so, with a statement of goneral couformity of habits, the subject may be left.

\section{PERDICIDE-Quails.}

\section{Oreortyx Baird.}

\section{O. pietus (Dongl.). Monntain Quail.}

Judging from the personal field experience of the past three seasons, this fine gamebird is much more numerous within an area of twenty-five miles of Carson than anywhere to the northward. In fact, it is only at rare intervals that it appears to cross the mountains and appear along the eastern slope. Evidence upon this point is not so full as conld ho clesired, since irs introdnction at the hands of man at certain points renders the question of its natural distribution in this region a difficult one to deternine. In general, it is safe to say that the places where they have reached and maintaincrl a residence along this slope are very few. Nevertheless, abont Carson, at Eagle aud Honey Lakes, Cal., and at The Dalles, on the Columbia, their presence was de- 
tected, and is to be acconuted for through the natural dispersion of the spccies. Elsewhere as at several localities near Camp Bidwell, Cal., the several covies are the closcendants of birds brouglit from the Pacitic slope and let loose to shift for themsclves. They are nowhere in this region. very numerons.

Desription of first plumage of yourig.-Prevailing color of the head, neck, back and breast grayish olive, more plumbeous beneath, and everywhere more or less spriulkled with white; the warkings on the breast larger and of more regularly deltoid forra chin, whitish; throat and cheeks mixed with dark plunbeons, a dusky auricular patch with an iudistinct whitish line just above. Crest, $1 \frac{1}{4}$ inches long; black, with tips irregnlarly marked with zigzag lines of pale fulvons. Scapulars, wing-coverts, tertials, and rectrices pale brownish, finely vermicnlated witl dusky. Abrlomen whitish; flanks marked with chestnut and white; bill blackish; feet pale brown.

\section{Lophortyx Bonaparte.}

\section{L. califoinicus (Shaw). Califoruia Valley Quail.}

This quail is nowhere indigenons along the eastern slope, as the high mountains offer a complete barrier to its extension. Those introduced about Carson appear to just hold their own.

\section{CHARADRIID正-Plovers.}

\section{Egralitis Boie.}

\section{A. vociferus (L.). Killdeer Plover.}

An abundant summer inhabitant of this whole region, the monntains excepted. Nests on the marshy borders of all the lakes. Numerous fresh eggs were found at Washoe Lake, Nevada, May 30.

\section{RECURVIROS'TRID E-Stilts, Avocets.}

\section{RECURVIrostra Linn:eus.}

\section{R. americana (Gmel.). American Avocet.}

Our knowledge of the rauge of this species over the United States is so full and complete that little remains to be added. Except inmediately upon the Pacific coast, wherc it is found in comparatively small numbers, no portion of the Rocky Mountains and the region to the westward has beon entered by our parties withont finding this bird, at the proper season and in suitable localities, abnndant.

During the migrations its distribution in the West is extremely general, and its presence is to be expected along all of the streams, ponds, and lakes, except, perhaps, in the highest mountainons districts, from the Mississippi to the Pacific.

In the breeding season its range is scarcely less restricted, and those sections only are exempt from its visits that lack the necessary requisites to its mode of life at this period.

In the neighborhond of Washoe Lake, Nevada, it is especially numerous, and here, about the middle of May, I fonnd the birds paired, while some, at least, were building. They were first noticed on some surall ponds near the shores of the lake, a locality quite typical of their choice at this season. The muddy flats of such little in lets always prove more attractive to birls of their habits than larger bodies of water, inasmuch as the slallows permit them to wade abont with perfect freedom; while food, which in sunmer consists very largely of the larves of aquatic insects, is more abundant in these tepid waters, as well as more readily obtained. I have sometimes thought that allalinc marshes and ponds were really preferred by these bixds, attributing this choice to the possible fact of the greater abundance of the larvo alluded to in such. Be this as it may, the fact that water happens to bo extremely brackish aud alkaline is at least no drawback to the avocets.

While the avocets are waders in the fullest meaning of the term, they are also adept swimmers wluen choice or necessity calls; but of this accomplishment, so far as my observations go, they rarely when unmolested avail themselves. I remember on one occasion to have seen a wing-tipped avocet trust itself plnckily to the waters of a broad lake and swim stcadily out, though in the face of a gale that I should liave thonght a dnck conld scarcely have stemmed; since which time I have always entertained a high opinion of the natatorial powers of this species, although, as rcmarken before, they are usually hold in abeyance.

On the occasion of my first visit to the place mentioned above, I found the bircls, with now and then a stilt, in cousiderable force, and so great was their soliciturle at my intrusion and so vehement their outcries, that I took it for grauted I was in 
immediate proximity to their nests. M search proviug of no aval, I accepted without hesitancy the apparent fact that I lad anticipated by a few diss theil nesting-time; and it was not nntil. June 1 that I learned the full extent of tho duception that the wily birds had practicerl upon me.

Whilo collecting at that date in a very similar locality half a wile or more np the lake, I fonnd myself possesscil of their sccret, and in the midst of a large colony of both avocets and stilts, while numbers of the nests of either bird rewarled an easy search. As was plainly to be seen, it was their foragiug trips that carried them away from home to the place where I had at first encountered them. Even at this remote point, their anxicty, real or pretended, had enibled them to effectually blind me as to the actual sitnation of their breching-gromud.

If the ontcries of the fow had been noticeable before, the confusiou of sound resulting from the combined numbers of the whole colony was simply hewildering. The unfortunate pair whose nest I tirst stumbled npon used all the artifices common to birds in such a strait to entice me away. They would run furtivoly abunt a few yards distant, and then squat close down to the crronnd, and grovel in the lonse earth as if settling over their egas, while they kept uittering sublued coaxiug notes as thongrh calling to imagrinary poung. Their effurts at simulating the actions of wounded birds, which was the evident significance of the drooping wings and staggering gait adopted, were not very successful, and the natnre of the deception was too appareut to decoive even a novico. After a while they appeared to beconse convinced of the futility of these attempts, and then rage took the place of sorrow. Flying about me in wide circles, the various pairs screamed and scolded till apparentiy exhanstcd by the excess of their emotions, when they betook themselves to a safe distance. I could not, help) fancying that the amount of sympathy extended the bereft birds by their ncighbors was in pretty exact ratio to the proximity of their own nests, those pairs being the most venturesome and vehement whose own danger appeared greatest, while away on the verge of the marsh stood quietly or fed leisurely about, in fancied security, those conples whose distaut homes seemed not to be threatened.

In placing its nest the avocet shows a certain degree of cunning, and for this purpose nsually avails itself of some little islet or isolated strip of marshy ground where its egrgs aud yonng are comparatively removed from the danger of intrusive visits fron all four-footed prowlers. One enemy the have from which this sitmation offers no protection. I refer to the inland gull of this region, the Larus californicus. Gulls, as is well known, are very fond of eggs, and never allow a chance of robbing other birds to pass hy nnimproverl. In the present instance the outcries of tho abused avocets had attracted the attention of a flock of the above birds that had been hovering over the lake, and, apparently scenting their opportunity, they swept in on poised wings or moved in gentlo circles, awaited a favorable nunuent to descend to the feast.

That both avocets and stilts were well a wale of the proclivity of these new foes was soon apprarent. For when one of the gulls, becomiug, perhaps, impatient, flew in close to the nests, all the birds near, forgetting on the instant their hmman enemy, combined to repel this fresh assault. Gaining a vantage crround above the big birds, they pounced down, striking their foes with wiugs and bills, until the gulls were forced to a hasty and iguominions retreat. These attacks and counter-attacks were repeated several times, until the gulls, discontited ly their warn recoption, left the vicinity.

The egrs are laid in plain view, and are quite nnprotected by grasses or other screening. The slight hollow, scratched and patted down in the damp soil to receive them, is occasionally quite thoroughly lined, oftener very slightly, with bits of weeds, stialks, \&c. The number of eggs varies from two to four.

\section{Himantopus Brisson.}

\section{H. nigricollis (Vieill.). Black-neck,Stilt.}

The mode of life of the stilt is, in all important particulars, like that of the avocet, and so invariably have the two birls been associated when under ms notice, especially at the breeding period, that anythiug which brings to mind the ove species is sure to recall the other. This compautonship is a proty accidcntal one, arising from an independent clioice of the same localities, under the promptiugs of similar tastes as to foor and other necessitics. Both are waders par excollence. Bnt if the stilt ever swins at all, and it doubtless possesses this power to a certain extent in common, I believe, with each and every member of its long-legged fraternity, it inust be only in extrcine emergencies. I have myself never seen it take to the water nuler any circumstauces. I many other minor particnlars of habits and actions the two birds differ.

In the West one may expect to find the nests of the stilts alternatinir at short dis. tances with those of the avocets, as if the two were nnconscious or at least indifferent to each other's presence. Indeed, in many instances it would be no eas.y task to satisfactorily identify the eggs of the two species in the rabble of parent birds that hover around the intruder, were it not for the fact that the very considerable difference of size in the bilds is exemplified in the egrs, those of the stilt being very perceptibly the smaller, corresponding with its more slender and everyway less bulky body. 
When a colony of the two species is disturbed, they seem to vie with each other in the importnnits of their attompts to misleal the intrider. 'lhus it often happens that the egr collector will find himself at his wit's end to dotermine the precise ownership of a clitch of egrs before him in the dozen or nore stilts and arocets which aro tlying abont. He has only to exercise a little patience and remain quiet nutil the excitument of the birds has had time to abate somewliat, whon pair by pair the strangers will drop' away till one or two only are left. From these he will soon be able to pick out the owners of the partienlar nest by their moro persistent and nanifestly groater solicitucle.

The young of both species leave the nest almost immediately ninom being hatched, and I have scveral times found them in a condition so weak and helpless that they seemed scarcely able to staud, mnch less walk; sugresting indecd, by their holplessness, the possibility of their having been renoved from the nest by the parent birds upon the first sigu of danger.

\section{PHALAROPODID R, Plialaropes.}

STEgaxopus Vicillot.

\section{S. milsoni (Sab.). Wilson's Phalarope.}

Of the three species of plialaropes the present is much the best limomn, probably because of its very general diffusion thonghont the interior, and bcculse it broeds abundantly with us.

In the region in question it has been found to be plentiful, loth as a spring and fall migrant and as a summer resident.

This phalarope was first noticed abont Washoe Lake, Novada, May 17, and the first arrivals from the sontl probably ocenr carly in this month. By the 2:3d nany had paired, and meh anxiety was manifested whon I approateded certain localities in tho marsh, where, however, I could find no nests. At this date they wero probal, ly just abont ready to lay, and a female, when dissected, was found to contain a well-developed egg.

For nesting purposes this bird appears always to prefer the borders of little pools, and the grassy, bogry edges of prairie slouglis, to the neighborhood of large borlies of water; and in this region one ralely approaches a locality of the nature of those first mentioned without being met by one or moro pairs of phalaropes, that come flying to meet the visitor with subdued and solieitous motes that clearly betray their anxiety to learn the character of lis errand.

As their mests and eggs have often been described, they need not be touched upon here.

Lomipes Cuvier.

\section{L. hyperboreus (L.). Northern Phalarope.}

Of more common occnrrence upon either coast, this plialarope is ret occasionally found in our interior dnring both the spring and fall migrations. Thins the last week of May the little ponds and inlets about Washoe Lalie were found to contain numeroms flocks, large and small, all which seemed to be in the greatest possible haste to reach points unknown farther to the north.

The little phalarope unites in itselt the characteristics of several families, and seems, as it werc, a solt of connecting link between them. Thus in it appear the gencral outlines and trimness of form that distinguish the sandpipels, joined to a plinage much like a duck's, while the lobing of tho feet appears to bo morleler after the plan of the coot's. Its habits express these peculiarities of structure very niculy, for in nimbleness it simnlates the sandpipers, if, indeed, it does not smlpass them; while vers few of the latter van compare with the lobe-foot in grace and elegance. Adrled to these qualities, its natatorial powers, when are taken into acconnt its diminutive size amd pigny strength, are really of first-class order.

It is difficult to imagrinc a more heantiful siglit than that presented by a flock of these phalaropes as in thoir brightly-colored unptial dress they pass with graceful action along the sliallows in search of foor. In some respects their movements when thus engaged are pecnliar and quite mnlike those of any other bird with which I am acquainted. 'The flocks I saw kept closely together, and in a compact body moved hastily along, weh hird gltaming the glonnd as he arlvinced by a contimons movement from side to side, the hod, being turned quickly; as on a pivot, and the bill lowered into the water with a guick thinst. This action gave each bird the appearance of describing at every movenent in full bilf circl", while the motions of the whole flock were so constant, lapid, and miform that they resembled more the actions of a living machine moved hy ono impulse than a flock of individual birds actnated by separite wills. In the manner described they passed in a very few moments over considerable space, and I thinli it likely that these floclis were actually mingating at the time; at all erents, the comse maintuined hy them, as long as they were nnoler notice, was a due
northerly one. 
Like most other spccies whose "make-np" enables them them to swim and wade witls equal facility, our phalarope prefers the latter, aud when feeding quietly only avails itself of swimning when it enconnters some decp channel that interferes with progress. Or, arain, when disturbed by too close scrutiny, they take to the water with an assurance that indicatcs it is 10 novelty to them. Thus they frequently becane alarmed under my espionage and swam to the midst of the pond, and, having put between us what they considered a safe distance, gathered quietly in a compact circle and awaited further developments with an air of wonder and innocent expectation that was very ammsing, as well, too, as tonching in its utter nnsophistication.

This species attains a nearly full development of the nuptial plunage within our limits, as was evidenced by the birds referred to here.

The females, as in case of the ot her two species, a re mueh the brightest of the sexes, and the most highly colored male hardly equals the dullest femalc.

Upon dissection, evidence appeared of strong sexnal exeitement in botl sexes, and I am inclined to believe that this phalarope will yet be found to breed along our northern frontier, possibly even in the mountains of Oregon. In fact, Dr. Cooper spcaks of luaving seen a pair of either this species or the red phalarope in the Cascale Monntains of Washington Territory in Angust, which he thourrht were probably breeding. The latter species has never fallen under ny observation in the West, and it is chielly naritime.

SCOLOPACIDAE-Snipe.

Gallinago Leach.

G. wilsoni (Tenm.). Wilson's Snipe.

Althongh the range of the Wilson's snipe during the migrations covers the United States from ocean to ocean, its breeding limits are mueh morc circumscribed, being chiefly along and beyond our northern borders. But in many of the inountainous sections of the far West it finds a climate and conditiens well adapted to its needs, and here it passes the summer at a somewhat lower latitude than in the East. In Oregon, as also throughont all that portion of Eastern California and Western Nevada to the north of the line of the railroad, the Wilson's snipe may be confidently looked for in smmmer in all the little mountain meadows and along such alpine streams as by virtue of their overflow are bordered by the soft, oozy spots which are so indispensable to its habits. As oftcn as otherwisc these tracts ocenr among pine timber at quite elevated altitudes.

I first became aware of its presence in Nevada June 15. At this date, while making camp jist at dusk near a small stream at the base of the mountains, I heard for the first time the peculiar sounds which are made by this suipe during the excitement of the love season, and I confess that at first I was not a little puzzled to explain their authorship. Afterwards I had several opportunitics to observe the birds in the very act of prodlucing them. The first impression received, shared in, too, by other members of the prarty as the sounds were borne to the ear fiom a distance, was that they were the notes of one of the small owls, muffed and disguised by reason of the remoteness of the bird. As the snipe flew nearer, and particnlarly as it passed directly overhead, the nature of the sound became more apparent, it then being comparable, as closely as anything I conld think of, to the whistling noise which is so marked a peculiarity in the flimht of the common dove (Zencidura). This was the comparison that was suggested to all the party at the time, althongh it fails to give a vcry precise idea of its jeculiar character. Mr. Ridgway hearing the snipe from a distance likens it to the "noise prodnced by water escaping from a nearly full jug," it having "a hollow, gurgling sound." Howertr observers may differ in interpreting its peculiarities, no one, I think, who hears under favorable circumstances the sound we have attempted to describe, is likely to agree with Nuttall in his supposition that the sound proceeds from the birl's throat. It is inquestionably due to the wings alone.

The modus operandi is somewhat as follows: Mounting high in air the bird flies rapidly and excitedly back and forth, and at intervals of every ninment or two, and while at full speed, the head is lowered, the wings bent and stiffened, and a downward plunge nade at an abrunt angle, which terminates suddenly with a sharp ascent; and it is at the moment that the downward is changed to the upward flight that the sound is produced. To make snch an extremely abrupt change in the line of flight possible, the wings must be bent into au unnsual shape, aud by reasou of their action upon the air comes the whistling sound.

During the nating, and in fact thromgh most of the brecding period, and continuing even after the young are hatehed, the birds begin these cvolutions as snon as dnsk comes on, and contiune them at irregular intervals until about nine o'clock. 'The notes are not heard again till about daybreak, and they cease before sun-up. But should the day be cloudy the snipe may be seen flying in the manner described till late in 
the morning, often. indeed till nearly noon. I think that the niales aloue are eoncermed in the produetion of these odd notes; but of this I am not sure. The sexes have a harsh call-note in common which they ntter as they fly casually about, which,

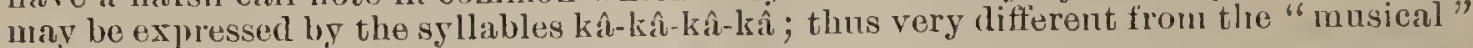
seaip-sajip, so fumiliar to every sportsman.

Other evidence is not wanting to show that our long-billed friend of skmlkingr proclivities allows the events of the love season to quite turn his liead, and varions are the idiosynerasies that take the place of his nsmal staid habits. One need not, then, be surprised upon prtting lim up in summer to find him alighting on a tree or fence-rail, and, so percherl, to stand for long intervals as though rapt in deep merlitation.

In the recrion in nuestion the snipe apparently begins to nest some time in May, and by the mirldle of June I found young not fully divesterl of the down.

Several nests were found with the cracked egg-shells lying immeriately about. Thes are usually built on a tussoek of grass, if indeed the term building is applienble to the slight structure nuade by bending down a few grass blades and adding a few bits of withered herlogge.

Tringa Linnacus.

T. minutilla Vieill. Least Saudpiper.

Common during the migrations.

Ereunetes Illiger.

E. pusillus (L.). Semipalmated Sandpiper.

As preceding.

Totanus Beehstein.

\section{T. semipalmatus (Gmel.). Willet.}

Present about Washoo Lake in May, where it probably breeds, as it eertainly does in many similar localities to the northward.

\section{T. melanolenens (Gmel.). Greater Yellow Legs.}

Numerous as a migrant. Flocks of this species were seen on their way south as early as Jnly $2 \%$.

\section{Tringoides Bonaparte.}

\section{T. macularius (L.). Spotted Sandpiper.}

A summer visitant thronghout this region, although not very numerous.

\section{NuMENiUs Linn:eus.}

\section{N. Tongirostris (Wils.). Long-billed Cnrlew.}

Numerous as a summer resident along the marshy borders of the large lakes, but most abnudant dnriug the fall migrations. In August' the stubble-fields near Goose Lake were fairly dotted with these birds, busily at work hunting grasshoppers.

\section{TANTALIDA-Ibises.}

\section{Plegadis Kaup.}

\section{P. guaranna (L.). Bronzed Ibis.}

This ibis has an extensive range in the west, it finding plaee as oeeurring at one season or another in nearly all the local lists of the eountry west of the Mississippi River. It reaches to the north as far as Sonthern Oregon, where it breeds. As the species was not found by Bendire abont Camp Harney we may perhaps assmme that the above is abont its northern limit. Nowhere is it more abundant than in the region from the line of the railroad to Northern California and Nevada, being there found in summer as an inhabitant of the tulle swamps on all the lakes large and small, except in the high mountains.

Its general habits are much like those of the herons, and the marsh and slough are not more essential to the mode of life of the latter birds than of the glossy ibis. During the migrations, it is true, floeks of ibises may be seen feeding in plain view in the open shallows along shore, but it is quite exceptional to find thom in sueh sitnations during the breeding season. Apart from their habit of nesting among the rushes the seem to prefer the secrecy and solitude conferred on them by the sheltering reeds, and 
if the marsb he treacherons and oozs so much the better is it likely to prove for their special purposes as favoring complete isolation. While duck-shooting the report of my gun las frequently started up a dozen or more of these ibises, that sprung with hoarse croakings from little muldy pools and recesses almost within stoue's-throw, where, screncil upon all sides, they had been quietly feeding withont conveying a hint of their presence.

Inherent in the natme of the ibis there is a certain wariness which to some extent makes amends for its uatmal stupidity. For, to few birls does the term stmpid apply with nore force than to the present species. The very " make-np" of the bird is snggestive of a slugrish disposition, there being evident a certain muginliness of form that it is inpossible to associate with keen intellectnal activity, and that is the very reverse of what is implice by the alert actions and elegant appearance of its allies, the herons. Donbtless the long, heavs bill and slender neck surmounting its thickset body contribute much to its unconth anpearance, and convey an impression which the really boautifnl plumage serves only partially to dispel. However, the ibis may safely claim that, oven if its appearance is not in all respects pleasing to the eye, its ensemble bas at least the beanty of utility, and its stont legs and long toes and claws, its heavy, curved bill and long neck all serve most admirably the purpose intended, which is, after all, the chief consideration.

By the 20tll of May the ibises all appenced to be paired abont Washoe Lake, although neither then nor a reek later was I able to find their uests. Perhaps this was a little early for the deposition of the eggs, although the oviduct of a female shot June 3 contained a perfect egrg.

\section{ARDEIDA-Herons.}

\section{ARDEA Linnans.}

A. herodias L. Great Blne Heron.

A common sumner inlabitant of this whole region.

\section{Herodias Boie.}

\section{H. egretta (Gm.). Great White Egret.}

Colonies of this species reside in summer on many of the lakes which lie at the foot of the momntains in Eastern California and Western Nevada, wlile we learn from Captain Bendire of an extensive heronry as high to the north as Lake Malheur, Oregon.

Warner Lake, jnst within the sonthern borders of that Territory, forms a favorite resort for several species of the heron family. The white egret mites with the others to form colonies that build their nests in the larger growtlof willows aloner shore.

Visiting such a heromry in Septembcr I found a dozen or nore of the partially fledged yonng swinging by the necks from the crooked branches where they hal evidently fallen as they clambered about the nests, and perishing miserably had bung till converted iuto innmmies bj the dry winds.

\section{Garzetta Kanp.}

G. coudidissima (Jacqnin.). Little White Egret.

Ohserved at several localities in Nevada and Eastern California where it is not so common as the preceding.

\section{Nyctiardea Swainson.}

\section{N. grisen naria (Bodl.). Night Heron.}

Pcrhaps the most abundant of the family, and preseut in all the marshes.

B. minor (Gm.). Bittern.

Botaurus Stephens:

A common snmmer visitant as far north as Southern Oregon, reaching perhaps in to Washington Territory as it does to Puget Sound on the coast. (Cooper.)

\section{GRUID A-Cranes.}

Grus Linnæns.

\section{G. canadensis (L.). Sandhill Crane.}

These large birds are nnmerons in so many portions of Nevada, California, and Ore. gon that it is scarcely worth while to particularize localities. 
They breed in many of the sub-alpine valleys, where are found meadows of sufficient extent to afford both food and protection, and to these and the tuleswanps they mainly limit themselves aud the young till the latter are able to shift for themselves. In some localities where such resorts are not avalable, an occasional pair of old birds may be seen accompanied by a young one or two feeding on the grassy plain or open stretelies of valley, where plenty of fool is found in the sliape of grasshoppers. Let once an Indian eatch sight of one of these families and he makes short work of the young birds, which are readily secured from horseback, or even run down afoot.

Towards fall the cranes beeome more nnmerous, or, at least, moreconspicuons, and in the region mentioned form a part of everyday scenc, as in sinall eompanies they feed about in open view or fly in long lines from one valley to another, uttering their indescribably odd notes.

I know of no other bird that carrics its instinet of eantion to so great an extent as does the crane; and he must be carefnl indeed or greatly favored by fortune who obtains a shot at onc.

The crane is usually held to be delectable fare; but ny own experiments upon them, as served np in camp style, have not been entirely satisfactory, and I have fonnd them tough and somewhat too gamey to bear the test of even a monntain appetite.

\section{RALLIDE-Rails.}

\section{Porzana Vieillot.}

P. carolina, Cab. Carolina Rail.

Found thronghont the summer, bnt apparently not so common as the succeeding species.

\section{Raluus Linnæus.}

R. virginianus (L.). Virginia Rail.

Numerons about all the marshy lakes.

F. amerieana (Gm.). Coot.

Fulica Linnæus.

An extremely abundant summer resident of all the lakes, large and small, of this regiou.

They begin to build, about Washoe Lake, Nevarda, the middle of May, at which date lut fow eggs had been laid, the majority of the pairs being still engaged mpon their
nests.

Their nests and nesting habits are too well known to need description here. A cluteh eonsists of from seven to twelve eggs. 'The latter number, however, is very exeeptional, nine being perhaps the average nestfull.

\section{ANATIDE-Dicks, Geese.}

\section{Cygnus Linnæus.}

\section{C. americanus, Sharpless. Whistling Swan.}

The swans are among the latest migrants from the north, and lience come too late to fall nuder observation of our field parties.

With the approach of eold wather they oeenr in most or all the large lakes of this region, as well also upon many of the large streams.

It is certain that the above species occurs as stated, and, in all likelihood, the C. buccinator is also fonud at the same time.

\section{Axser Linnieus.}

A. gambeli (Hartl.). Speekle-bellierl Goose.

Towards the last of Angust in Northern California this speeies began to arrive from the north in eonsilerable numbers. It becomes very abundant at a somewhat later
date.

\section{A. hyperboreus, Pall. Snow Goose.}

Arrives rather later than the preceding, and perhaps in rather fewor numbers.

The Chen (Chen Rossi) has been found by Captain Benclire at Malleur Lake, Oregon, and in all probability is of regular occurrence as a migrant on the interior chrain of linkes. The past winter (1878-'79) it has been oxceptionally numerous in tho Sacra-
mento Valley and along the eoast. 


\section{Braxta Scopoli.}

\section{B. canadensis (L.). Canada Goose.}

The extensive lakes of Western Nevarla, Eastern California, and Oregon, afford summer hannts for many of the Canada geese, or honkers, as they are popularly called, to distingnish them from the smaller Hutchins" groose and the "speckle bellies," neither of which birds remain in summer within our boundaries.

The nesting scason of the Canada goose is well vigh over ere others of the feathered tribe, save perhaps some of the Raptores, are thinking of beginning, and the deposition of the eggs talies place in this regrion as early as February. Their mode of nesting is varions. At Pyramirl Lalse the islands are extremely rocky, and here the gresse builh cither under bushes aloug shore or resort to spaces underneath overhanging cliffs, or even to hollows in the rocks that form slight caves. Another and perhaps the most nsmal location for the nest is on the sandy spits of islands. The wariness which characterizes this goose, as to a less extent the other members of the famils, nudergoes no relaxation at this season, but, if anything, is increased. The spot selected to reccive the eggs must be secure from all chance of intrissionhence their partiality for islands; and as soon as the young are able to take to the water they are gruided to some safe feeding ground, usually in the slatlow water along sonie solitiry shore. This care is renclered the more necessary, inasumch as a long period inust elapse for the young to receive their full powers, and they obtain neally the size of the old birls ere their pinions are snfficiently developed to raise them from the water. Not infrequently, when riding along the rarely-visited shores of tho lakes in the remoter districts, onr parties have come suddenly upon these families of half-grown goslings, but rarely indecd ere the watcliful parent had caught the alarm and had urged her convoy to a safe distance from the shore. Their food is now obtained wholly from the water, and not until the ronng have passed quite ont of the gosling stage and have become fully developed in every respect do old and young assemble into flocks or "gaggrles," and their visits to the stubble fields and pastnres begin.

Tho birds that breed in this region start southward at a period nearly coincident witl or a little before the arrival of the full flocks from more northern grounds. Just prior to setting ont they are in the best condition, being fat and juicy from their mingled fare of grain and teuder grass shoots.

\section{Avas Linnæus.}

\section{A. boschas (L.). Mallard.}

One of the best known, as also one of the most highly estecmed, of all our ducks, its extensive range and great abundance wherever found, entitles the mallard to a place in the front rank of our valuable food-birds. In the West, as a table bird, it takes precelence, I think, of all others, its very general habit there of feeding upon grain for a part of the ycar conducing to its excellence of flavor.

In the region our report covers it is very numerous, not onls dnring the migrations, but also in summer, when large numbers remain to breed about the rarious lakes. For this purpose it resorts to precisely the same localities as the red-breasted tcal, viz, the partially snbmerged marshes; althongh, in truth, but little change of locality is in case of either of these birds necessary, since their tastes lcad to the choice of similar places all the year round. So much alike, in fact, are their habits of nidification that during a day's hunt I have found many uests of the mallard alternating with those of the teal, and in many instances the nests of the two were but a fer fcet apart.

The mallard loegins to lay during the last days of April and the early part of May, and by the $2: 3$ d of the latter montli I found severul nests in which the eggs were far alvanced, while in one the ducklings had appeared.

The mallards place their nests much as do the teals, but are, perhaps, more inclined to seek ont standing tnfts of dried rushes, donbtless becanse in then they can nore readily conccal their bnlkier bodies; at the base of these they have no difficnlty in forming a safe and commodions retreat. At first, and in the majority of cases, little attention is paid to the nest proper, and a slight collection of dried rushes and grass, snfiiciently lollowed to contain the eggs and the body of the bird, is all that is reqnired. The lining of soft down, plucked from the breast and belly of the rlevoted female, is deferred till later, it rarely being found till the complement is nearly completerl, and it more frequently still being left mntil the eggs have bcen incubated for a considerible period.

I have nover fonml more than ten eggs in a nest, though $I$ have seen broods of eleven nnder convoy of the parents, and perhaps the full dozen are sometimes laid.

When disturbed tho mallard rises heavily from its nest, its firight occasionally compelling a volley of lond quacks, while at other times it flies away in perfect silence. In 
case of the female, she may then show her concern by flying in wide circles near the nest; and this she is especially likely to do when the maternal instinct has become strong by long brooding. But should the nest contain only a few newly-laid crgs, much less apprehension is displayed, and then she flies straight away to remain iu hiding for some hours, or until completely reassured. Often, under the latter circumstances, the nest is never reoccupied, but a secoud begun after a delay of trenty-four hours or so.

Soon after being hatched, the downy young are led by their parents, not into open water, where wonld follow a well-uuderstood danger from hawks and other enemies, but into the shallow inlets, where thes can be screened by the heavy covert of recds; and they are not allowed to venture out of these until able to shift for themselves. I think that for the first few nights after being hatched the tender young are lerl back and brooder in the nest. But the interval during which the jonng are most exposed to danger is in the "flapper" state, or when they have attained considerable size, but have not yet received thepower of flight, for the rectrices, as is well known, are the last feathers to be developed. They now flap along the surface of the water in a curious sort of way, half flying, half swimming, and when cornered in shallow water, as may often be done, they fall easy prey. This is the accepted time of feasting for numerous species of hawks, not to mention snch formidable four-footed encmies as cosotes, foxes, etc., while most to be feared of all is its human foe in the shape of the Indian. Armed with clubs, the boys and squaws enter the shallows, and by beating the reeds drive the young before them till they are congregated in some favorable spot, when they are slanghtered by the scores. I have seen Indians returning from one of these ducking expeditions fairly loaded down with spoil, the joung ducks hangiug by the necks in festoons, and almost hiding by their mumbers the dusky bodies of their slaughterers. Dncks' eggs and ducklings form in fact during summer no small part of the' ludians' fare.

Probably none of the mallards raised in this region pass the winter here, but migrate south, and are replaced by more northern-born birds, so that abont the numerous warm springs and ponds of open water the mallards are to be found throughout cold weather, until spring once more impels them northward.

D. acuta (L.). Piu Tail.

\section{Dafila Leach.}

Abuudant during the inigrations; one breed.

\section{Cinaulelasmus Graj.}

\section{C. streperus (L.). Gadwall.}

This fine duck breeds abundantly throughout this region.

\section{Mareca Stephens.}

M. americana (Gm.). American Widgeon.

Breeds more or less commonly in this region; most abundant as a migrant.

\section{Querquedula Stepheus.}

Q. carolinensis (Gı.). Green-wing Teal.

Scattered pairs of this tcal breed over all this region, and in some localities it is doubtless numerous.

While crossing the desert north of Reno, carly in July, we found in the solitary pool of Tater, which with its scanty growth of greeu rushes forms the only oasis for niles around, a family of this teal consisting of a femalo and teu yonnin. The pool being of too small extent to furnish shelter in such danger, the mother bird led the band to the shore and directly into the sage-brnsh, into which they divod and hid as thongh fully alive to the emergency of the case.

This teal is most abundant as a spring and fall migrant, its proclivitics heuce being for more northern summer grounds.

Q. diseors (L.). Blue-winged Teal.

This species was not seen at all during the summer; nor, as a nigrant, docs it aplear to be as numerous in this regiou as either of its congeners.

\section{Q. cyanoptera (V.). Cinnamon Teal.}

This teal is one of the few ducks whose range is so far circumscribed that it may be spoken of in gencral terms as a western spocies, the area ocenpied by it, oven during the migratory seasons, not extending to the east of the Rocky Mountains, except in 
Texas. Althongh noted from Lonisiana, its occurrcnce there is presinmed to be quite accilental. It furthermore appears as a smmmer resilent in almost every section where it is known at all. It breerls abont the Columbia River, at present its northernmost recorded linit. Sonthern Colorado, on the other hand, as determined by our parties, is inclnded in its summer range, as possibly also Arizona and Now Mexico, although of the latter fact no alosolute proof was obtained. In many localities in the intermediate regions it is onc of the nost abundant of snmmer visitants, and in no place more so, according to my knowlcdge, than in Western Nevada and the contignons regions.

It makes its appearance on the lakes of Nevada early in the spring, at a date nearly coincirling with the general impctns northward to be obscrved in the ducks and water birls generally. At the time of my first visit to Washoe Lakc, May 12, all of the 1eal appeared to be paired, while not a few had so far progressed in their housekceping matters as to already liave eggs.

With all the ducks there is noticeable a great variation in the time of nesting, eren at the very same locality. The cinnamon teal forms no exccption to this rule, and from the above date onwards $I$ fonnd nests in all the rarious stages of advancement. Fresh eggs were found as late as the 1st of June, although most of the nests at this clate contained either young or eggs very far advanced. Perhaps a certain proportion of the late breeders are to be accounted for on the supposition of the destruction of the first nests, for ducks have nany enemies at this season; and fresh dnck-eggs as well as yound birds have an especial attraction for all the smaller carnivores.

The téals' nests will be fonnd scattered over a marsh at large, thcir chief care beiug to sccure a dry spot out of reach of the danger of inundation, which is their prucipal risk, and the callse at times of the destruction of great numbers of the eggs. Some seasons of high watcr about Washoe Lakc, as I was told by the ranchmeu, prove most ruinons to the first clntches, and the swollen inlets of the marsh have been observed at snch times to be fairly lotted with eggs of the rarions kiurls of ducks, which harl been floated off by the rising waters.

An apparcntly secure locality fonnd, a pair soon satisfy themsclves with some special little nook. They never, I think, bnild in the heavy berls of tnle, bnt either select an isolated bnnch of rnshes, or else place the nest in the midst of the short waving marshgrass, where it is snfficiently thick to protect the setting bird from ordinary olservation. Occasionally, too, they nest upon the dry land nuder a bush, and more or less distant from water. But in any event the nest mnst be within easy reach of a good feeding gronud, and is usmaliy not many yards, perhaps but fer feet, distant from some pool or stream. Dueks have plenty of opportunty for the exercise of cunning in their domestic arrangements, and some of the pairs display infinite address in hiding their nests, and the ejes of the most observant collector, be he two or fonr footed, will often in vain scrntinize the very clump of grass whercin is hid the mother bird nestling close down to her treasures, secnre, till a blnurlering step starts her from her eharge. If a clump of rushes bo selceted as a nestiug site, the bird enters from the side through a space so small that, once inside, it necds bnt a fer slight touches of the bill to replace the stalks disturbed by her entrance, and restore everything to its natural appearance. And this the female is kuowing enongh to do, as she is also to carefully cover the eggs dnring her temporary absences. Like the mallard, and probably most if not all other ducks, the cinnamon teal is very indiffercnt as to the state of the nest at the time the first eggs are laid, and leaves the final touches till towards the period when the yoming are aboit to appear. Then, to provide a soft bed for her offspring, the female quite denndes the nnder portions of her body of its downy feathering, and with the material obtained in this way warmly felts the nest.

The teal is a close setter, and the fcmalc will occasionally prove so devoted to her eharge as to permit lierself to be eanght by liand. If the young be out, there is scarcely any linit to the hardihood she will show in her attempts to distract attention from thein. She ilntters along the gromnd just beyond reach of the outstretched band, and resorts to every effort of dissinulation likely to induce pnrsuit. I have seen the wommded, br oken-winged bird, in particular, imitated so cleverly by this teal, that it was difficult indcel to persuade myself that it was a cheat.

The extreme nnmber of eggs at a hatching is, I believe, trelve; and in some thirty nests examined at Washoo Lake this number was found only twice; nine, ten, and elcven being the more common complements.

In fair seasous the greater number appear to be hatched ont, as I never saw a small brood; and occasionally every egr proves fertile. 'That this should be the case seems a little remarkable, when is considered the irregularity which marks the intervals of deposition.

When nowly laid the eggs are of a beantiful, soft, creany white, and the texture of the shell is delicatc and a trifle rough under touch. Very soon after the fnll comple. ment appears the shell becomes smooth and shining from the constant contact and rubbing of the bird's body, and the delicate tcxture is lost cntirely. The color is also correspoutingly changed, and now appears as a light buff, which darkens and stains 
as time goes on. Such are the nsual musenm speeimens. Their exaet shape is somewhat indeterminate, since, in the sets before me, many approach the true ellipsoidal, while others are simply oval in varying degree; some are elongated and cuite prointed at the smaller ends; others are blunt. It is to be remarked that the peculiarities of size and shape are apt to obtain with but slight variations throughont the whole of in set. The two smallest eggs before mo measure $1.88 \times 1.27$, and $1.82 \times 1.32$; and from this oxtreme they run up to $2.10 \times 1.3 \%$.

The cimmamon teal is, in the interior, one of the very first of the dueks to start in fall on the sonthward migration, and, in the neighborhood of Washoe Lake, nearly all have left by the first of September; while those that breed farther north are not long in following.' In California it remains later, and I nnderstand from my friond, Mr. H. G. Parker, that more or less winter in the Sacramento Valley.

\section{Spatula Boie.}

\section{S. clypeata (L.). Shoveller.}

This duek is abundant in fall and spring in nearly all portions of the West. Nevertheless if it remains to breed, it does so apparently only in rare instances, except along our northern border, as in Dakota, where the young were found by Dr. Cones in Angrist.

It is true that I detected the species at Washoe Lake in Jnue. But upon killing a male the cause of its stay so far sonth was revealed in the shape of an old wonnd; probably, too, a greater or less number of barren birds are scattered over the lakes of this region.

\section{F. marila (L.). Greater Blackhead.}

Fuligula Stephens.

Numerous only as a migrant and winter visitant.

F. affinis Eyton. Lesser Blaclshead.

Occurs as the preeeding.

\section{F. collaris (Donov.). Ring-neck Duck.}

In notieing this species on previous occasions, especially in the report for $18 \% 6$ I have given it as brceding in Utah, Novada, \&e. I was led into what I now am convineed was a mistake by the incorrect identifieation of several young birds. These Inow ascertain to have been the young of the redhead ( $F$. americana), as similar speeimens taken the past season of nuquestionable identity show. I take this oceasion therefore to make the correction, and all such referenees are to be understood as applying to the redhead, and to it alone. We have no proof at the present, so far as I am aware, that the ring-neek breeds within our limits, and it donbtless retises in snmmer to points far beyond our boundaries. During both spring and fall it oecurs in greater or less numbers according to locality.

\section{F. ferina americana (Eyton). Redhead.}

Better known, perhaps, as a bird of the east coast, the rodhead is yet a well-representer species on the west coast, and also to a somewhat less extent of the western interior. It was found breeling, though not in great numbers, about Wasloo and other lakes in Western Nevarla and the eontiguous portions of Californix. This is, I believe, a summer range muel farther south than is usually understood to apply to this species; although young birds taken at Rush Lake, Sonthorn Utah, by myself, affords good evidence of its summer residence at that point.

Its method of nidification is in general inuch like the other species. One nest found by Mr. H. G. Parker was somewhat singularly placed, in that it was built in perfectly bare, open ground. A hoof-track in the mud, which had subsequently been left high and dry by the reeding waters, recoived the nest, composed in this instance entirely of feathers and down, there being, in faet, no room in the narrow quarters for other accunnlations. A second was bnilt elose to the water's edge nnder protection of a little chinp of grease-wood bushes. The egrs numbered in these instances respectively tive and seven, incubation in neither liaving begmu.

I append the measurements of three of the first set, merely remarking that, except for their more spherical form and perhaps rather larger size, they would bo indistinguishable from the mallard's: $2.23 \times 1.73,2.21 \times 1.73,2.17 \times 1.70$.

\section{BucEPIIALA Baird.}

B. clangula (L.). Common Golden Eye.

An abundant migrant.

B. albeola (L.). Buffle-head Duek.

As preeeding spiecies. 


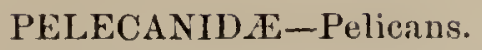

Pelecaxus Limnaus.

P. erythoryuchus Lath. White Pelican.

The white pelican is less known from its occurrence on either coast than from the abundant numbers that inhabit the grent interior lakes. From their great extent, and in many instances complete isolation, as well as their containing an abnudance of fish, tho lakes of Nevada, Califurnia, and Oregon are especially favored by this bird, and on certain of thenl, as Pyramid, lagle, and Gonse Lakes, the pelicans are found in summer in immense numbers.

So much has been written from time to time npon the breeding habits of this species, that most persons interested in the subject may be presumed to be pretty familiar with then!, and this part of the bird's biography lieed not be enlarged upon here to any extent.

Naturally the white pelican seems to be rather stupid, and, when the privacy of a brecting colony is cheroached upon for the first time by a human being, the liveliest feeling his presence is apt to excite is intense curiosity, which is oceasionally carried to such in extent that the birds appear as though too completely overwhelmed with astonishment to take any special precantion for their own safety. Under such circumstances they may occusionally be so closely approached as to be killed with chusis. No creature however so dull as not to profit by the lessons that experience teaches, and the freatment the pelican usually receives at the hands of man is of such kind that in him they snon learn to recoguize an enemy to be feared and shunned on all occasions. Such is the case at Great Salt Lake where the former great abuudance of the pelican is atfested by sil the early explorers, but where now the bird is known only as a casnal visitant. Persecution is having a similar result at Pyranid Lake, Nerada, where a few years ago the birds wcre so tame as to permit themselves to be almost caught by liand. At present, though sill abundant, they are excessirely shy having been driven entirely away fron certain of the islands by treatment which must eventnally cause their conplete disappearance.

From its large size and consnicuons plumage, and the habit of colonization at the nesting perind, added to the complete exposure of the eggs npon the sands, and finally from the fact that the young when hatched are perfectly helpless for a period of over a month, the pelican is peculiarly exposed to the assiutt of its enemies. From four-footed foes it secures immunity by nesting mpon islaurls, a precaution which, of conrse, proves of no avail from its human persecntors.

At Pyramid Lake a crusade has been inangurated against the pelicans by the fisherman, whose canse is justified in their own eyes by the voricity of the big birds, and the number of fish consumed by them. In a single day, as I was informed, over 700 eggs belonging to one colony were destrosed. This complaint of injury done the fishing interests is not, it must be said, without some foundation. The number of pounds of fish consumed in a day by the combined numbers of a large colony of pelicans, especially when feeding young, must anomut to something fabulous. As a rule, however, and from the natnre of the mode of fishing practiced by the white pelican, fish of value, as the tront, are but little exposed to their attacks; the species they are able to obtaiu consists chiefly of the smaller fry fonnd in shallow water, and of littlo or no table-valne wlaterer, their principal, if not their only, importance being as food for better kinds. As this small fry fairly swarms in all the western lakes, there is no danger at present, at least, that the fishing interests will be injured in this indirect nianner, as ind ced is plainly evidenced at Pyramid Lake, where, despite the number of the pelicans, trout exist in enormons numbers.

The method of obtaining their prey by banding together, driving the fish before them into shallow water and then scooping them up with open bill by means of quick rushes, I have often wituessed and is well known. The large size of the fish a pelican, under emergency, is able to dispose of, is somewhat surprising. I once saw a bird which had been wonnded, and which was apparently nuable to clear the surface of the water, throw up a sucker which I estimated to weigl not less than three pounds. Having rid itself of extra ballast to this extent, it flew away with ease.

The deposition of the pelicans' eggs takes place at a very early date; the colnny at Pyramid Lake, as I learned, having laid many eggs by April 10, and this is I think about the usial date. As might be presumed, all the pairs of a colony do not legin laying at the same time; in faet there is much irregnlarity in this respect, and as a consequence there results a corresponding difference in the time of appcarance of the jonng. This was clearly shown in the ease of a community of from 500 to 1,000 pairs that harl established themselves on a sandy island in Eagle Lake (Cal.), and which I visited July 4. At this date the young were present in all stages of growth, from the chick just breaking the shell to the soungster fully grown, but still unable to fly. A 
rough estimate placed this number at considerably ovor 1,000, aud a nore incongruous assemblage was never wituessed. As our boat approached the island the parent birde lyeran to manifest some nueasiness, and when we were abont two grmshots aw aly they ruse en menss and steted in the riater at convenient distande fur watching our procecdings. The yomnglingswere considerably flustered when they fund such strange

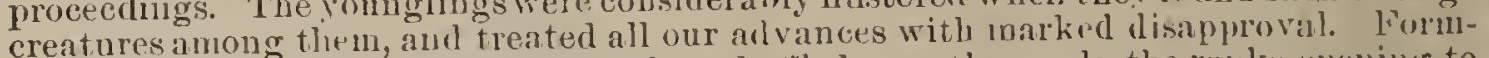
ing into solid phatanxes of all sizes, they shnthed over the simels, the ranks openimg to right and left with all alacrity according as we lirected our steps. Tho appearances they cut as they $r$ addled about on theil nustrady legs, sone of them almost naked aud all ngly and uncouth, was ludicrous in the extreme. Even thoulder on's minle no attempt at aggressive resistance when captured, but were content to show their repugnance at being bandled by riolent efforts to escape from our hands. Finslly, in response to the couxing of a few old birds that ventured in, many took to the water, and, having sw:m out three or fonr hnndred yards, remaincd qnietly eyeing our movements with all unconceru. Many gulls and scveral pairs of cormorints and great blue

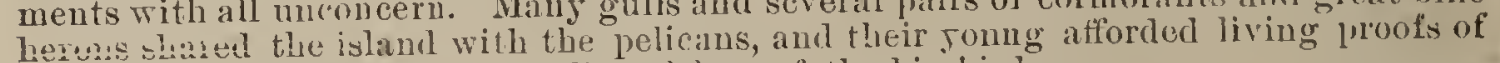
the unruffled tempers and good dispositions of the big birds.

At the fotes the nelinans prosented a peculiar!y noteworthy sight as at intervals during the day they sprearl their broad wings and tiew in bands of from fire to fifty to tho neighborhood of some one of the lofty peaks within a mile ol two, where they ainuserl themselves by salliug abont for an lour at a time in the invigonatiner air and in encompassing the smmnits in wide eircles. 'Their suowy-white plumage reflected the bright sonlight, and the huge birds appeared at their best as they soared above cañon and forest at such height that all ungainliness of form was lost and we were left to ahwire the snowy purity of their colors and theil time powers of flight.

The "centre-burtu," so called, a horny excrescence appcaring on the bills of the adults about the mating period is, as has becn shown by Captain Bendire, common to both sexes. This is shed as the season progresses, till, in early July, when the yonng are usually well advaluced, it is rarely seen, although a fer still persist at this time. Of its use nothing a!luears to be known.

\section{GRACULID E-Cormorants.}

\section{GracULUS Limnans.}

\section{G. dilophus (Sw.). Double-crested Cormorant.}

The cormorants from this region have usually been reforred to the variety foridamus, a name bestowed upon what was supposed to be a small southern race of dilophus. But my pair of specinens taken at Pyramid Lake, Novada, in summor, are fully np to tho requirements of size of dilophus, and $I$. thercfore so consider them. It is to be remarked, however, as has been indicated by Mr. Ridgway, that specimens occur in the region under notice, and in California, that are no larger than many Florida born birds. After examination of the Suithsonian material I am of the opinion that the alleged difference of siza is of too doubtful applicability-to warrant the recognition of this variety.

The louble-crested cormorant is more or less numerons on many of the lakes of this region, its abundance at any given locality being chiefly regulated by the presence and character of nesting facilities.

All the nests examined by ne were built in depressions and eavities on rocky islands, although in this same region they build upon trees, as fully attested by Mr. Ridgway. The nests were composed chiefly of sticks with a substantial lining of woeds. One was noticed that hal an additional slight felting of feathers. No birds could well be less fastidions in regard to their nesting arrangoments than they, and the foul orlor about a cormorant rookery is almost unendurable. Entangled in one nest that 1 oxamined was the mummied head and nock of a brother cormorant that apparently liad been gathered as available nest material.

Althongh the flight of the cormorant appears heavy and somewhat laborions, it yet progresses from feeding ground to feoding ground with tolorable oase and much swiftness. But the bird appcars at its best in the water, where it is scarcely less at homo than the typical divers, and where no little of its existcnce is passed boneath the sur. face in pursinit of its finny prey. This the cormorant never plunges for, but, like the grebes, divers, and other birds of that class, the bcst swimmers of all, captures it in full chase. The bird's forays are usmally made into large schools, and apparently it lias very little trouble in procnring all it requires. The eormorant is not always succossful in holding a fish after it has fairly seized it, and at Eagle Lake there wore to bo soen in every school of white-fish (Coregonns villiamsoni) a eonsiderable number that boro across their bodies the marks of the powerful mandibles. I found quite a mumber of sizable fish that had cscaped from the birds' bills, only to die a liugering doatl from the effects of compression. 


\section{LARID X-Gulls, Terns.}

\section{LARUS Linneus}

\section{L. euliformicus Leter. California Gull.}

The present species is to be distinguished from the L. delarerensis, which it somewhat closely resembles, by the following characters:

L. califormiens, adnlt-size larger; bill stonter ; (wing, 15.43; tail, 6.24; bill, 1.82 ; depth aliove notch, .60; tarsus, 2.23 ).*

Mantle rlark pearl blue, much darker than in the succeeding. Color of bill (in fresh specimens, sometimes retained in skins) bright yellow, with an irregnlarly shaped spot of inlense earmine near tip of lower mandible; a spot or bar of black anterior to this on both mandibles. Iris hazel or brown; tarsi and feet pale green.

L. delcwarensis, adult-size sualler; bill less robnst; (wing, 14.49; tail, 6.06 ; bill, 1.45 ; depth above nostril, .51; tarsus, 2.07 ). +

Mantle pearl blue, always lighter than in precenting Bill greenish yellow, encircled near tip by a broad black band. Iris light yellow ; tarsi and feet naples yellow.

The amount of black on the bill of californicus is variable. Usually it takes the form of spots or bars, as given above, but such is by no means always the case. Not rarely, as in several alult speeimens before me, it appears in the form of a complete eircle as in delercarensis. In such cascs, however, the ring is much narrower than in that bird. More rarely the black is almost or quite obsolete. Similarly, or even more variable, is the amonnt of white at tip of tirst printary. In a majority, perhaps, of specimens this is fomul as a terminal patch of about two inches in extent. Some individuals, however, apparently perfectly arlult, have the tip and sliaft black for three-fourths of an inch, the white being restricter to a spot on either web above the black area, almost preciscly as in delaterensis. Others, again, may have the extreme tip white, above which is a band of black including both webs and the shaft, and griviner way, higher mp, to a second white area which may or may not include the shaft; sometimes, indeed, the shaft is biack alove and white below. Hence the spotting of the primaries and the black markings of the bill, points npon which considcrable stress has been laid by sone anthork, are too inconstant to prove reliable gnides in diagnosis, although not entirely without viluc.

In fall the allults of either species have the white of hear mole or less spotter or streaked with duskr. The carmine spot on the bill of culformims tades away, as also the crimson of eyolids and at augle of month, which is common to both species. The differenees in size, espccially of bills, and the color of the mantles may now be relied upon to separate then. 'To distingnish ronlug birls, which always exhibit so much individual valiation, becomes much more difficult, and I have founl the size of bill to be the best aud most constant feature.

The Californian gull is found as a very abundant summer resident throughont the entire chain of lakes, and is, so far as I can learn, the only representative of the funily present bere at this season. Upon stretches of sand, juttine out from the little islands in micl-lake, or occisioually among the rocks along sbore, this gull constructs its nest, and deposits from two to four egrrs about the middle of May. The nest is a somewhat rude and lulky structure, partieularly if it chances to be placcl in rocky interstices, and is composed of rceds, sticlis, and similar coarse material gathered from the shores, :urt lined more or less substantially with finor glcanings.

The colonies are, as a rule, very large, one that I visited on Pyramid Lake containing several hmudred pairs, and the nests occmpy every available spot on the sands. Unfortunately for the gulls, the ecgrs are rich and sulficiently well flavored to be a welcome addition to the meager fare of the settler, and hence, when accessible, are eagerly songht for. The colony alluder to above had been visiterl every few days for a period of uore than three weeks, and evcry nest riflcd. 'But so tenacionsly do the bircls cling to a spot that luas once been chosen as a nesting ground that many still continucl to deposit egrss, sometimes in new/r-constructed nests, but often in the plundered ones. Many of the females har laid so of ten that the coloring pigment harl been exhiuusted, and, as a eonsequence, a considerable portion of the later eggs were almost nuspotted. The eggs of this gull are so nearly like those of the ring-bill as to be practically indistinguishablc, although they average a trifle larger. In the exact style and anount of markings they vary interminably.

\section{I. delcurerensis (Ord.). Ring-bill Gull.}

Given by Captain Bendiro as a "common smumer resident" of Mallenr Lake, Oreg. It is possible that a mistake has been malc here, and that the statement really applies only to the L.culifornicus. If correct it funisbes $1 \mathrm{~s}$ with the only instance of the bird breeding within the United States. Tpon all the other lakes in California and Nevada 
that I have risited the ring-bill appears to be only a fall and winter resident, and as such is numerous.

\section{Sterna Linnicus.}

\section{S. forsteri (Nutt.). Forster's 'Tern.} Dr. Cones appears to have received an entirely erroncous inpression in regard to the
breeding range of this species, and assigns the interior of British America as its sunzmer home, implying in his article in Birds of the Northwest its entire absence from the United States at this season, although he intimates a possibility of its being yet found to nest on or along the northern tier of States. The truth is this tern is an extremely abuudant summer resident of Washoe and other similar lakes of Nevada and California east of the mountains upon wlich are found any considerable extent of tule or otler marsh. It also occurs abnndantly in summer in the great fresh-water marshes in the vicinity of Chicago, and also in Wisconsin. Upon the eastern coast its summer range is somewhat erratic, as it appears to be wanting along the New England coast, but is found at this season, in great numbers, on certain of the islands off the shore of Virginia and to the soutliward. Its absence farther north is, perhaps, to be aeconnted for from the lack of suitable localities, since the Forster's is as much of a marsh-loving species as the black tern, in contradistinction to the Wilson's, arctic, and others, whieh habitually frequent the open water, or, at least, avoid more the sedgy marshes.

Upon the western lakes the Forster's and black terns mingle fraternally together as they conduct their search for food over the broad expanse of oozy marsh or along the shallow, reedy shores. Moreover, the Forster's term, instead of building on the open sands, has recourse to the marshes, thus still further following the habit of the black tern.

The single nest found by me cousisted of a few bits of débris, and was placed on a muddy bank by the side of a ditch of running water.

\section{Hydrochelidon Boie.}

\section{H. fissipes (L.). Black 'T'eru.}

This species, which is a well-known inhabitaut of our lakes both east and west of the This species, which is a well-known in Nevada early in May, and by the 10th of the
Mississippi, makes its appearance in Nevald
month is very generally dispersed.

A bird of the slonghis and reedy marshes, wherever found, its habits cliffer in but fer and unimportant particulars. The character and extent of its nest vary soncwhat with the locality it inhabits. Thus Dr. Cones tells ns that it builds no nest of its own, but finds the matted débris of weeds a sufficient protectiou for its eggss, while Mr. Nelson's experience near Chicago was in effect that it invariably builds a substantial nest of its own, whatever the foundation may be. In one particular the clistom of the species, wherever found, seems to be very uniform, namely, for all the pairs in a given locality to adopt the same plan, which is naturally deternined by surrounding eircumstances. In Nevada the method of nidification appears to be various, the nests in some neighborhoods being placed among the waving grass in a tolerably dry situation; in others, on firm tnssocks; in others still, on beds of matted tnles. In any event the formation of a certain amount of material of the bird's own gathering into some sort of a nest scems in this region to be the rule. I may note herc some curions lesting sites selected by a largc colony of these terns, which harl established themselves in a slough that contained enough open water to form the lome of numerous grebes ( $P$. auritus californicus): The uests of the grebes, from whith tho romng had departcd not long before, harl been utilized by the terus, and hasty gatherings of bits of dried rushes and the like had been placed upon the half-decayed and wholly filthy masses to receive their eggs. The utter lack of fastidionsness of the terns was finther exemplified in the fact that in nearly every case their own eggs lay in close proximity to the rotten and abandoned eggs of the first occurnants. In fact, in one or two instances the terns must have fonnd it difficult to inculate their own corgs withont partially corering one or more of these. At this date (Jnly 24) some of the eggs were in the advaneed stages of incubation, whilu others had been hatched. The most voeiferous of the fimily under evory-day circumstances, such an occasion as the present is snre to call out all the bird's powers of noisy vituperation. The cries of the pareuts as they flew close down to the nests liad the clesired effect of cansing the young to hastily abandon the nests and seek shelter in the grass. One old bird that was sitting on an egg from which the bill of the imprisoner chick was just escaping refused to lave her charge at this critical jnneture, and actually pernitted me to approath in plain sight and take her in ing hand.

Fish forms an mnimportant item in the bill of fare of this species, as, unlike others of the family, it fcerls in great part 1 pon insects, which it takes in various ways, mostly als they fly from the griasses.

'The species is present in Nevida during the latter part of Angust in somowhat dimjushed numbers, but in September all leave for the south. 
DESCRIPTION OF NESTLING.-Head above smoky brown, the same color prevailing below, but beeoming darker aeross the jngulum and lighter on abdomen; sides of head and loral region white; baek and sides of body pale ciunamon brown, interspersed with irregular patehes of blaek; bill black; feet brownish.

\section{COLYMBIDE-Divers.}

\section{Colymbus Linnæus.}

\section{C. torquatus (Brunn.). Great Northern Diver.}

From information reeeived from various sonrees I had been led to consider this diver as of rather uneommon oecurrenee in the waters of this region. During the past season, however, it was met with several times on Eagle Lake, Cal., where a number of pairs breerl regularly, and the same is true, I think, of Goose Lake, where, at any rate, the speeies was observed by onr party dnring the late summer.

\section{PODICIPID A-Grebes.}

\section{PoDicers Latham.}

\section{I. occidentalis (Lawr.). Western Grebe.}

None the less striking beeause familiar is the appearance of this large grebe as seen upon the extensive lakes of Nevada, and the comntry generally west of the Roeky Monntains. At what time in the spring it makes its appearance in these latitudes I do not know. On the oceasion of my first visit to Washoe Lake about the middle of May the water was dotted with water birds, and eonspicuons among them, as well by its elegance of form as by its graeeful motions, was this grebe. Subsequently, when in turn I visited the several lakes lring to the northward, I found it an abundant inhabitaut of them all. Indeed, with the oxeeption of Lale Tahoe, I know of no large body of water in the far West that is exempt from its presence. The high elevation of Tahoe, over 6,000 feet, probably acconnts for the absence of the hird, as in all the other mountain lakes of less eleration I have always found it present in abundanee.

There is a pretty elose correspondenee in the cliaraeter of the food, the manner of obtaining it, and in the habits of niclifieation of the various species of this faniiy, and my observations have not shown that the western grehe possesses any very marked individuality in these respects, mnless snch as arises from its great size and superior prowess in manner of obtaining food. 'The largest of our speeies, the present bird excels all the others in natatorial powers, and in its ability to remain a long time submerged, in which partienlar it alnost rivals the loon. It is probable, therefore, that this grebe is able to avail itsclf of its remarkable powers in the capture of fish, and it hence lives more upon them than do the other smaller and less powcrful speeies. But fish do not, I thiuk, form by any means its principal diet. The larvie of all arnatie insects, varions worms and lceches, as also some kinds of aquatie plants, make up its ebief dependence.

'The western grebe is a wouderfully quiek diver, as I have lial neeasion to learn when after specimens, and I have found it almnst imprissible to kill the old and wary birds evell at very short range, provided the bird was not taken unawires and could see the flash of the gim. Howerel true the aim, and whatever the precaution as to the plaee aimerl at, the leaden pellets when they reaeher the spot found only enipty space, where a moment before was to be seen the long, snaky neck of the cunning diver.

It is about the 1st of Jume when the varions speeies of grebes begin to think of their domestic dnties, and if they be watched now they will be found to have gathered together into loose enmpanies, which are to colonize together later on, and to spend much of their time in swimming back and forth in a rather excited manuer just off one of the many clumps of tules that grow around the margins of most of the western lakes. 'The shallow deptlis abont such form, it is true, favorite liunting gronnds at all seasons, but around the conmaratively few spots that possess the neeessary qualifications for nesting purposes the eoncentration of the birds will be more marked as well as more persistent. The thieker tangled reeesses among the tules are shmnned, and only those spots among the season's fresh grow th selected, where the tall reeds, while affording ample protection as well from the waves of the open lake as from ehanee olsservation, will yet admit of unimpeded progress in swimming to and from the nest. Such a place found nmmerons pairs center in and form a sort of independent eolony, and the preparations for the nest are leisurely gone on with. A few of the surrounding tule-stems are perhaps sroken off or bent down, and other reody material gathered and laid in a pile, the strueture being ready for oceupation when a slightly hollowed and homogeneous mass of this is raised so as to fully clear the surfaee of the water. 
Nonc of the many nests I have examined, either of this or the other species, liaro been moored as flescribed by some antiors. They liave nsmally been lerfectly free, except in so far as the recks constitnting a hedge about them offer a complete check to the chance of their floating oft. Occasionally, it is trme, a few of the surromming stems have been beut down and made to enter into the composition of the nest. But this is rather rare, and is apparcntly to be looked npon as an entirely accidental circumstance, so far as any intention of anchoring tho structure is concernct.

A less promising place to deposit eggs than the structure rescriber can scarcely be imagined. 'The naterial, which is mostly gathered from the water, is muldy and soggy, and how it is possible to hatch eggs on such surroundiugs is a mystery to all but the grebes. The problem appears to be casy enongh of solntion to them, and solve it they do in a most satisfactory manucr. I have never been successful in nuy cfiorts to catch sight of a grelse on its nest, and partly on this account, partly from the peculiar character of the nest itself, have been ler to surmise that much of the labor of incubation is shirked by the birds of this family and is delegater to the warmth of the sun's rays, aided, perhaps, by the heat which arises from the decomposing nest material. Lilie other specics, as the eared grebe, the present hirrl covers up the egrs in its absence, although occasionally I have fomm them exposed to view. I have never found more than four eggs to a nest of this species, but mesmme that this mumber does not represent the full complement.

The young bogin to appear abont the first of July, but mang priss at this clate will

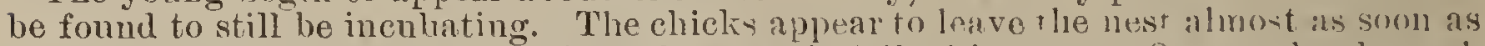
hatched, and their history at this early stage is full of interest. One need only pmsh his boat throngh the tules at this season to find hinself rewarled bs the sirgt of somo domestic scenes that will well repar his trmble, and will perbaps give him a higher idea of these birds of "low instinct" than is nsmally acorrel thens. The reerly recesses are full now of guaint noises, not hearl at otber seasnlls. The faint tmackings of the young ducklings convoyed by their watchful pareuts, the liash nues of the

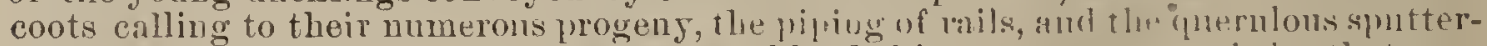
ing notes of the ever bnsy marsh wrens, are blended into a common molody, that now sweils into full chorus, now dics away into confused mumurs under the fitful milsmmmer's lireezes. But notes, too, other than the above are to be made ont in the confused gabble, viz: the high pipiug call of the grelyes, and, if he manages adroitly, the observer will find himself directly in the midst of a family group or gromps contuining all the hirls just mentioned. His appearance will be the signal for a hasty scattering of the startled community, but, whitever of the scene he may fail to take in, let him not overlook onr grebe just now. At the first sign of danger the pair of old bircls have warned the young, that respond with feoble pipings, and at the call placing themselves on the broad flat backs of thcir parcuts, who have ranger mp alongside for the purpose they are transported to a place of satety. No more beantiful and tonching sicht can be imagined than tiat presented by the downy little creatmes as they lmalle close up to the old oue's neck, and give themselres trinstinly up to its profoction. Both pareuts share equally in the care of the young, part of the brood accompanging vne, part tho other. In this minncr, they are carried about from feeding ground to feeding gromul, or renoved wheu danger threatens. Even at this very eary age the chiclis, under emergency, are wonderfully adept at diving and swimming, and to catch one minjurch is a matter of no little difficnlts.

A brief description of the young in the downy stage, hitherto undescriberl, is suhjoined. First stage: Body above, dark sooty brown, lightest alous sides. Head and hind neck light asliy plumbeons, in contrast to the under parts, which are puro white. Bill black, extreme tip light pellow.

When abont half-grown, and while still in the down, the young differ considerably from the above in color. The head above is then of a blackish brown, and the down on hind neck shows the same color at base. It would appear that the growtl of down is continuous for a considerable perior, the ends boing constantly worn away by attrition, and that its color just prior to the replaccment by the true feathering corresponds with that of the latter.

\section{P. auritus culifornicus (Hecru.). Eared Grebe.}

This dimimutive species appears to reach its maximm of abundance only as we al $1^{-}$ proach the west coast. In Nevada, Oregon, and California, it is bs far the most numeronsly represented of the family, and mily be fomd at the right scasom on any and all the lakes and ponds of this region, where exist the proper nesting facilities. I'hongh apparently absent in snmmer over much of the interior rexion proper. through all which, however, it migrates, it has been ascertained by Dr. Cones to bredalunantly along our northern frontier, as in Daliota, while on the other haud a sizable colony was found breeding in Southern Colorido, by myself. This may prove to be an cxtrowo point in its smmmer range, but I think not, and that there is at least a probability of its occurrence still farther south, in Arizona.

Much of the accomnt of the breeding habits of the previons species will apply equally. 
well to the present birl. The nests are the same characteristie structures, the only difference heing nne of size, and the eggs are deposited abont the same time. The habit, mentioned clsewhere, of covering the eggs with a perfect sorocu of woeds seems to he ereig where a consiant one with the eated grebe, and I have never found a nest in which the egrs conld be seen withont tirst uncorering them.

Both parents share in the care of the yommg after birth, and, as in the ease of the larger species, the joung are carried about on their backs. The filluilies are difficult to find at this seasou, as they rarely visit the open water, but keep sedulnusly within shelter of the tnles, whence their shrill calis may bo heard coming from all direetions, au' yet not a bird, yonng or old, be seen, nnless extreme eare be taken in approaehing them.

The following is a rescription of the romng:

First stuge.-Head aboveblack; a faint yelluwish white line begins at base of bill, divirles on foreliead, ann passes orer either eye to hind neek; the lattre is also streaked with white. Body above blackish brown; each down shaft tipped with ash; sides washed with phumbeous. Under parts rosy" whit.

As will be uotieed, the young of this species differs sufficiently from the similar stage in any of the others as to be readily identitiable.

\section{Ponilyaibus Less.}

I. podiceps (L.). Pier-hill Grebe.

Although not nearly so ahundant as the eared grebe, the "dabelick" is yet aluundantly represented ou the waters of this region in summer, and doubtless also to a greater or less extent as a resident speeies. 'The Pied-bill nests in the same loealities as the eared grebe, and in the general particulars of habits the two agree closely.

The young of the present bird have very deeided markings about the head, broad white and dark lines being eontrasted alternately. On the back of the liead are several irregular patehes of bright rufous. 

Gaylord Bros. Makera

Syracuse, N. Y. PAT. JAH. 21, 1808 


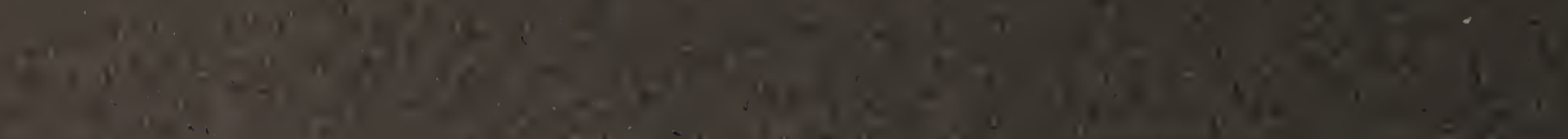

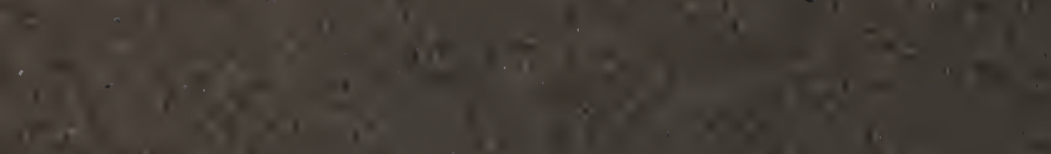

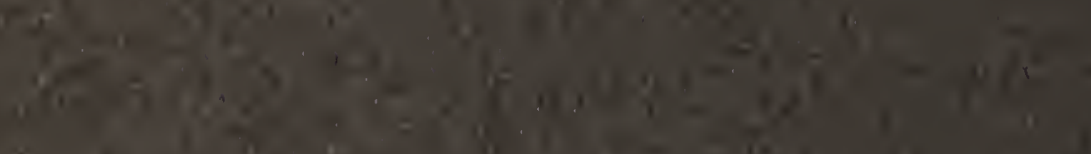

(1.5.

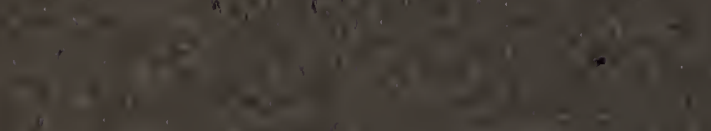

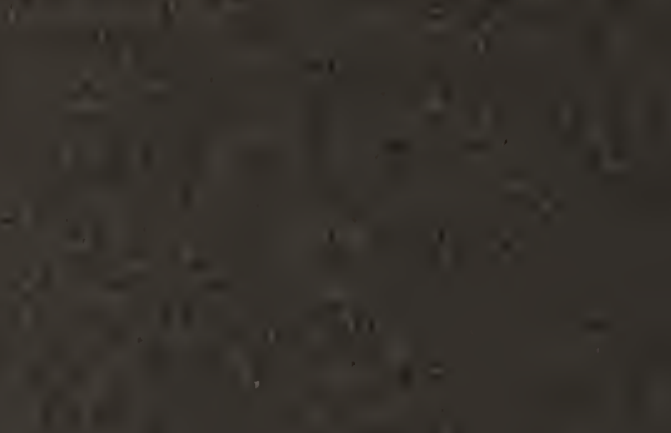

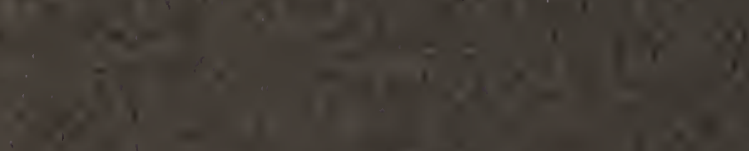

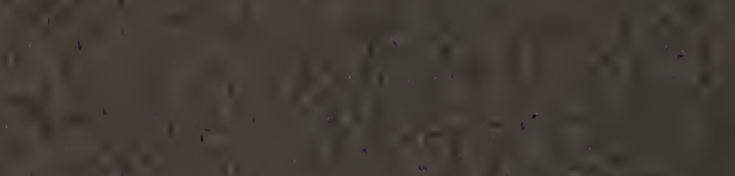

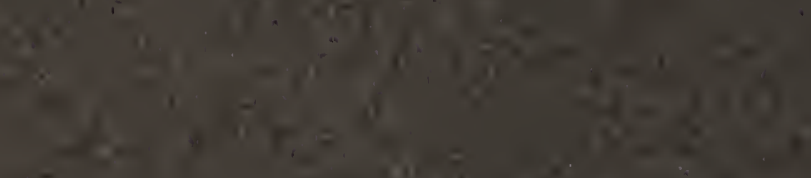

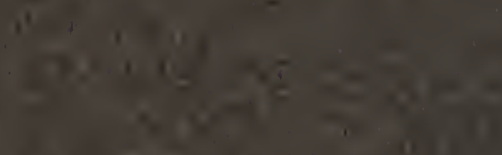

$$
\begin{aligned}
& \text { 2. } 2
\end{aligned}
$$

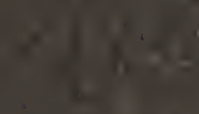

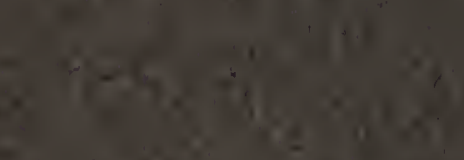

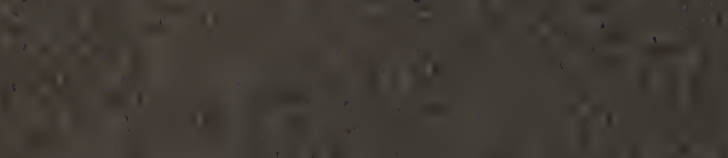

$\therefore x+1=0$

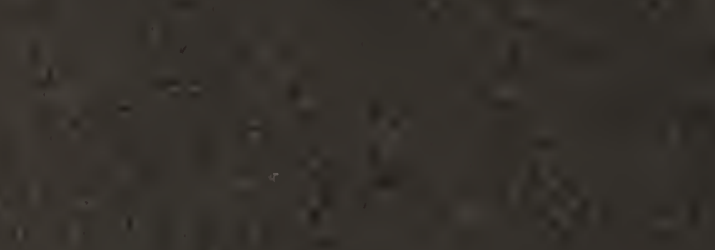

$11-8=$

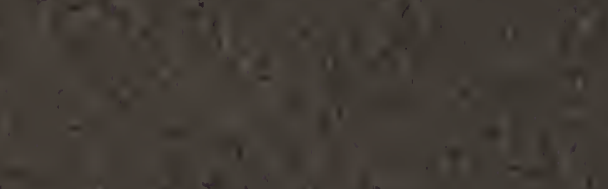

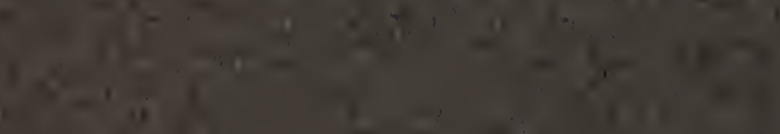

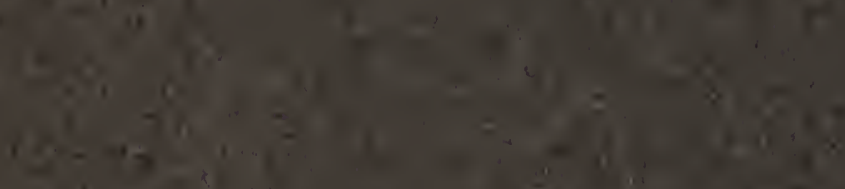

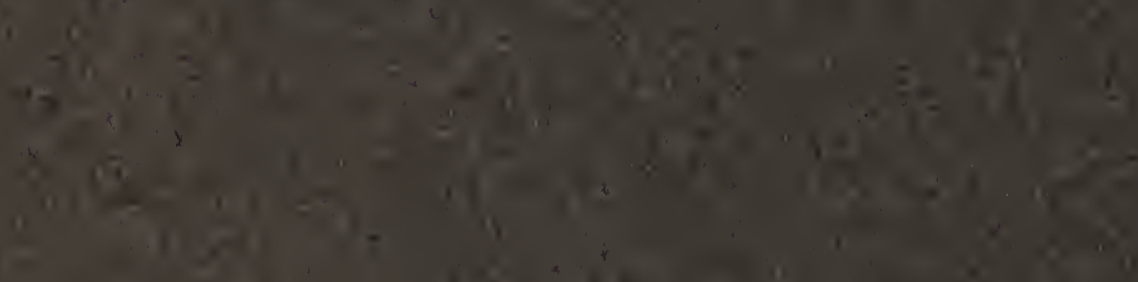

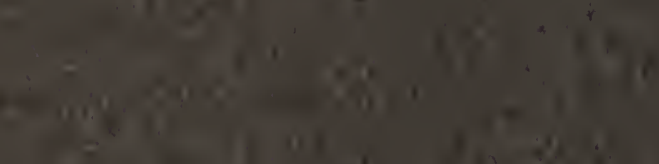

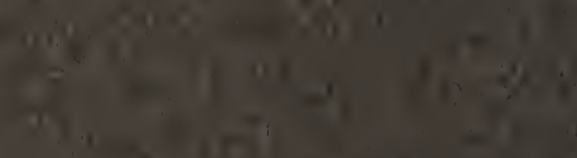

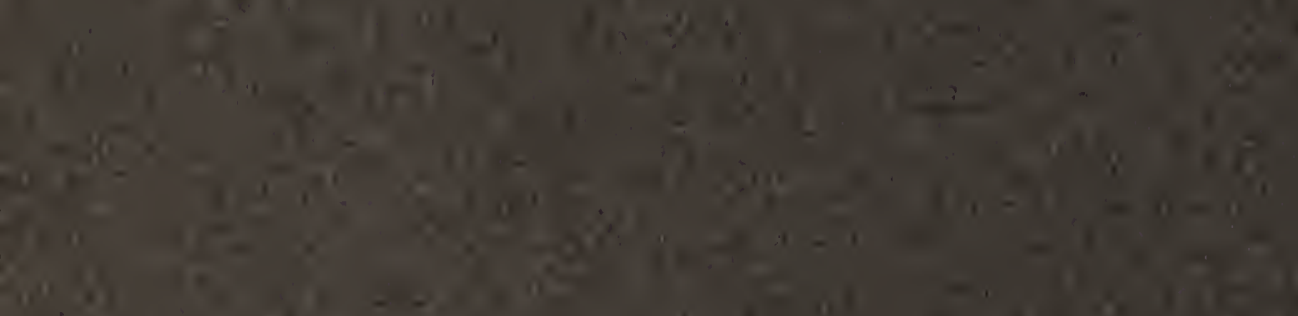

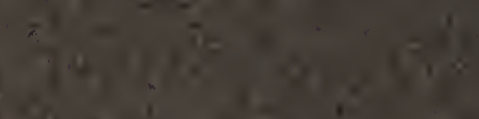

$3^{3}, 1$

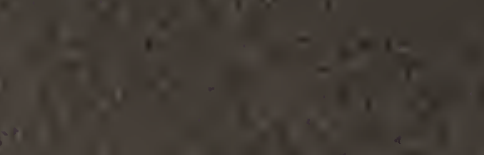

$=x^{2}+3 x+2=$

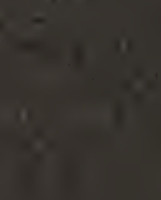

$i^{2}$

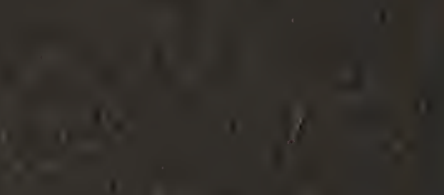

$\operatorname{lin}^{3}+1 \cdot=$

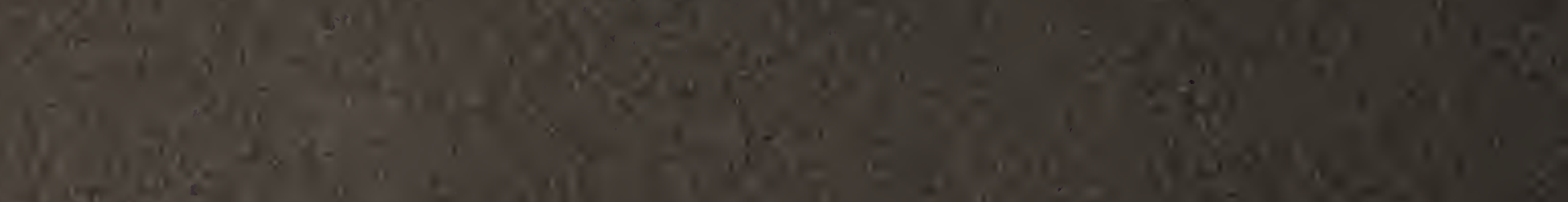

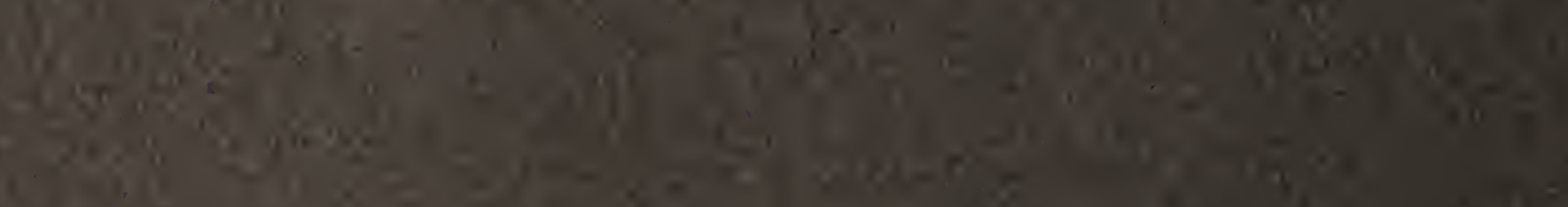

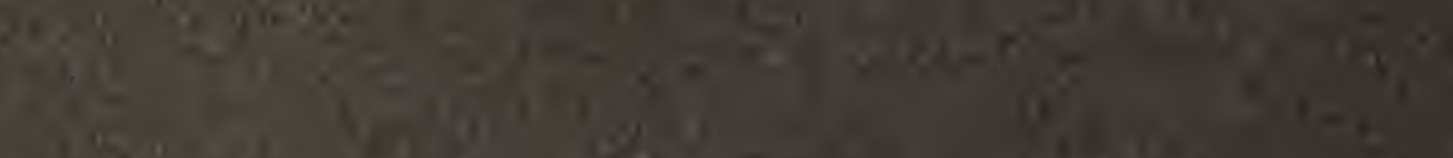

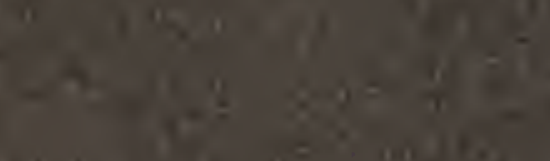

(2.)

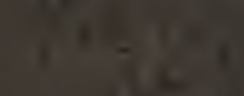

